\title{
IV. UPPER EOCENE AND LOWER OLIGOCENE DIATOMACEAE, ARCHAEOMONADACEAE, AND SILICOFLAGELLATAE IN SOUTHWESTERN PACIFIC SEDIMENTS, DSDP LEG 29
}

\author{
Marta Hajós, Hungarian Geological Survey, Budapest, Hungary ${ }^{1}$
}

\section{INTRODUCTION}

DSDP Leg 29 began on 2 March 1973 at Lyttleton, New Zealand, and ended on 18 April 1973 at Wellington, New Zealand. During the cruise, 16 holes were drilled in the area south of Australia and New Zealand and in the Tasman Sea (from $40^{\circ}$ to $56^{\circ} \mathrm{S}$ and $143^{\circ}$ to $178^{\circ} \mathrm{E}$; see Figure 1). The present report is an evaluation of the upper Eocene-lower Oligocene diatom assemblages of 27 samples from 18 cores taken at Sites 280 (in deep water south of the South Tasman Rise), 281 (in shallow water, on the South Tasman Rise), and 283 (Central Tasman Sea).

The diatoms, archaeomonads, and silicoflagellates were studied, and photographs taken, using an Amplival binocular light microscope with $40 \times$ and $100 \times$ objectives and $10 \times$ and $16 \times$ oculars. Diatoms are the principal biostratigraphic indicators in the siliceous sediments because of their abundance and good preservation; foraminifers and nannofossils occur in subordinate numbers or are absent. For more precise stratigraphic control and for paleoenvironmental purposes, the entire siliceous microfossil assemblage was studied. The distribution of siliceous microfossils in Leg 29 sediments is shown in Table 1, and the frequency distribution of characteristic species is shown in Figure 2. The following section summarizes the occurrence of siliceous microfossils at all sites drilled during Leg 29 .

\section{SUMMARIES OF LATE EOCENE-EARLY OLIGOCENE SILICEOUS MICROFOSSIL-BEARING SEDIMENTS IN DSDP LEG 29 SITES}

Site 277 (Latitude $52^{\circ} 13.43$ 'S, Longitude $116^{\circ} 11.48^{\prime} \mathrm{E}$, on the southern Campbell Plateau)

This hole penetrated a calcareous nanno ooze rich in foraminifers. It contains scarce, poorly preserved, and corroded siliceous microfossils. The tests are covered by a siliceous gel which could not be removed in the laboratory without damaging or decomposing the siliceous test.

Site 278 (Latitude $56^{\circ} 33.42$ 'S, Longitude $160^{\circ} 04.29^{\prime} \mathrm{E}$, in the southern Emerald Basin)

Miocene, Pliocene, and Pleistocene diatom and nanno ooze and nanno-bearing siliceous ooze layers are alternate at this site. Poorly preserved, corroded, fragmentary diatoms occur only from Core 31 , Section 1 $(295.5 \mathrm{~m})$ to Sample 33 , CC $(424 \mathrm{~m})$. The sediment is

\footnotetext{
'Publication authorized by Dr. J. Konda, Director of the Hungarian Geological Survey, Budapest.
}

tentatively regarded as being of middle to upper Oligocene age, but cannot be directly correlated on the basis of the flora with the diatom ooze of Hole $280 \mathrm{~A}$ and Sites 281 and 283.

Site 280 , Hole $280 \mathrm{~A}$ (Latitude $48^{\circ} 57.44^{\prime} \mathrm{S}$, Longitude $147^{\circ} 14.08^{\prime} \mathrm{E}$, south of Tasmania and the South Tasman Rise)

The stratigraphic sequence in this hole consists of silty and clayey diatom ooze from Core 1, Section $2(9-11 \mathrm{~cm})$ to Sample 4, CC (38-91.5 m below the sea floor), and upper Eocene to lower Oligocene greenish-gray diatom ooze and silty clay with diatoms from Core 5 , Section 1 $(120-122 \mathrm{~cm})$ to Core 8, Section $1(120-122 \mathrm{~cm})(91.5-145$ $\mathrm{m}$ below the sea floor). Siliceous microfossils in these sediments are well preserved and are very abundant in Cores 1 through 7. In Core 8 they are less abundant and poorly preserved, and lower in the section they are absent; dissolution during deposition or diagenesis is suggested.

Dominant in the assemblages are several species and varieties of the genus Stephanopyxis (Asterolampra schmidti, Stictodiscus californicus var. nitida, Cerataulus pacificus, Hemiaulus incisus, Kisseleviella carina, and Rouxia rouxioides) which are short ranging and appear only at the lower boundary of the Oligocene (Tables 1 and 2).

Site 281 (Latitude $47^{\circ} 59.84$ 'S, Longitude $147^{\circ} 45.85^{\prime} \mathrm{W}$, in shallow water, on the southern slope of the South Tasman Rise)

The sandy and silty clay and diatom ooze of Cores 14 , 15 , and 16 were analyzed in detail. They contain a wellpreserved siliceous microfossil assemblage rich in species and individuals. Dominant in the floras are subtropical, neritic-thermophilic planktonic forms with a depth range of 200 to 400 meters (Tables 1 and 2). This assemblage resembles that of the upper Eocene of New Zealand as well as that of the upper Eocene of Site 283 in the Tasman Sea. A significant proportion of the diatoms are through-ranging species, while others disappear in the upper Eocene. Some of the latter are endemic planktonic forms.

Site 282 (Latitude $42^{\circ} 14.76^{\prime} \mathrm{S}$, Longitude $143^{\circ} 29.18^{\prime} \mathrm{E}$, west of Tasmania in the magnetic quiet zone)

All the cores from this site were studied and found to be barren of diatoms as well as any other siliceous microfossils. Only in the core catchers of Cores 5 through 7 were some undeterminable diatom fragments found. Siliceous sponge spicules are commonly of great diversity in Cores 5 through 17 (upper Eocene to upper Oligocene); they are abundant and large and can probably be compared with those observed at Sites 280, 281, and 283 (Eocene and Oligocene). 


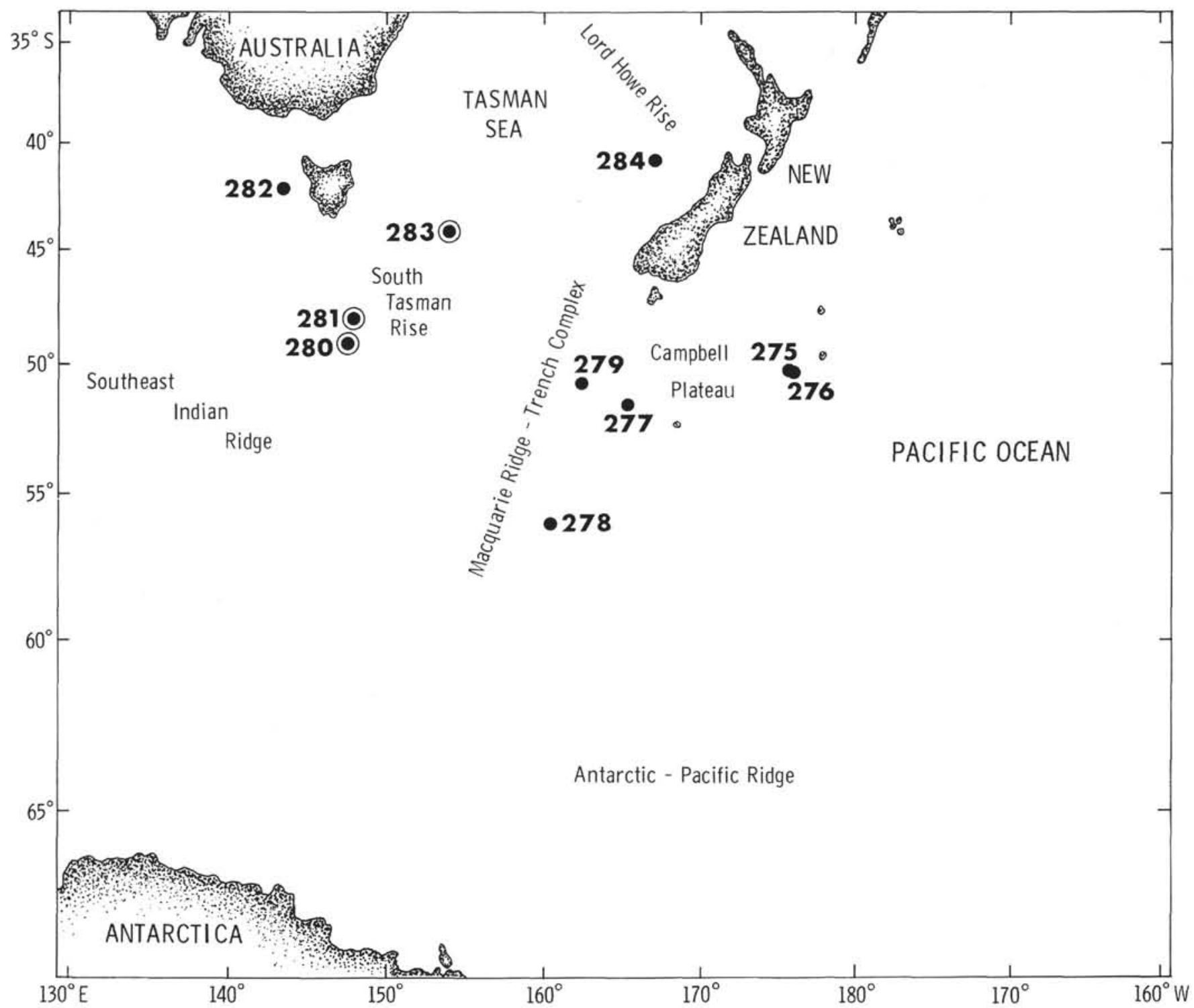

Figure 1. Location of sites cored during Deep Sea Drilling Project Leg 29.

Site 283 (Latitude $43^{\circ} 54.60^{\prime} \mathrm{S}$, Longitude $154^{\circ} 16.96^{\prime} \mathrm{E}$, located in the Central Tasman Sea)

Upper Eocene detrital silty sediments and diatom ooze were recovered in Cores 2 through 7 , while silty clay with diatom detritus was recovered in Core 8 . From Core 9 down, the sediments were barren of siliceous microfossils. On the basis of species dominance, two units can be differentiated: (a) from 283-2, CC to 6, CC the following species dominate: Melosira architecturalis, Stephanopyxis antiqua, S. grunowii, S. longispinosa, S. superba, and Naviculopsis biapiculata var. constricta; (b) from 283-7, CC to 8, CC the number of species is smaller in every sample; the most characteristic species are Xanthiopyxis panduraeformis, Pyrgupyxis, and Pterotheca.

\section{DISCUSSION}

A number of studies based on diatoms deal with the Pliocene through Holocene interval of the Pacific Ocean (subarctic region, North Pacific, East and Central Pacific, and the equatorial region). These studies indicate that the regional distribution of diatoms is affected mainly by subarctic and North Pacific currents (Kanaya and Koizumi, 1966; Donahue, 1970; Jousé et al., 1969, 1971; in Koizumi, 1973, p. 805, 827-829). In the present case, the diatom assemblages consist mainly of thermophilic, subtropical diatom species. Antarctic or subantarctic species are absent or only doubtfully present. According to the literature (Grunow, 1884; Hustedt, 1927-1930), 11 of the species listed in Table 1 are Recent. However, I have become convinced during the course of my studies that the species described by Grunow (1884) from Franz Joseph Land are extinct, and that their occurrence in Recent sediments must be due to submarine redeposition of Eocene sediments. This admitted, the actual proportion of Recent species is $5 \%$.

The majority of the species studied became extinct at the end of the Eocene or in the Oligocene. Accordingly, 


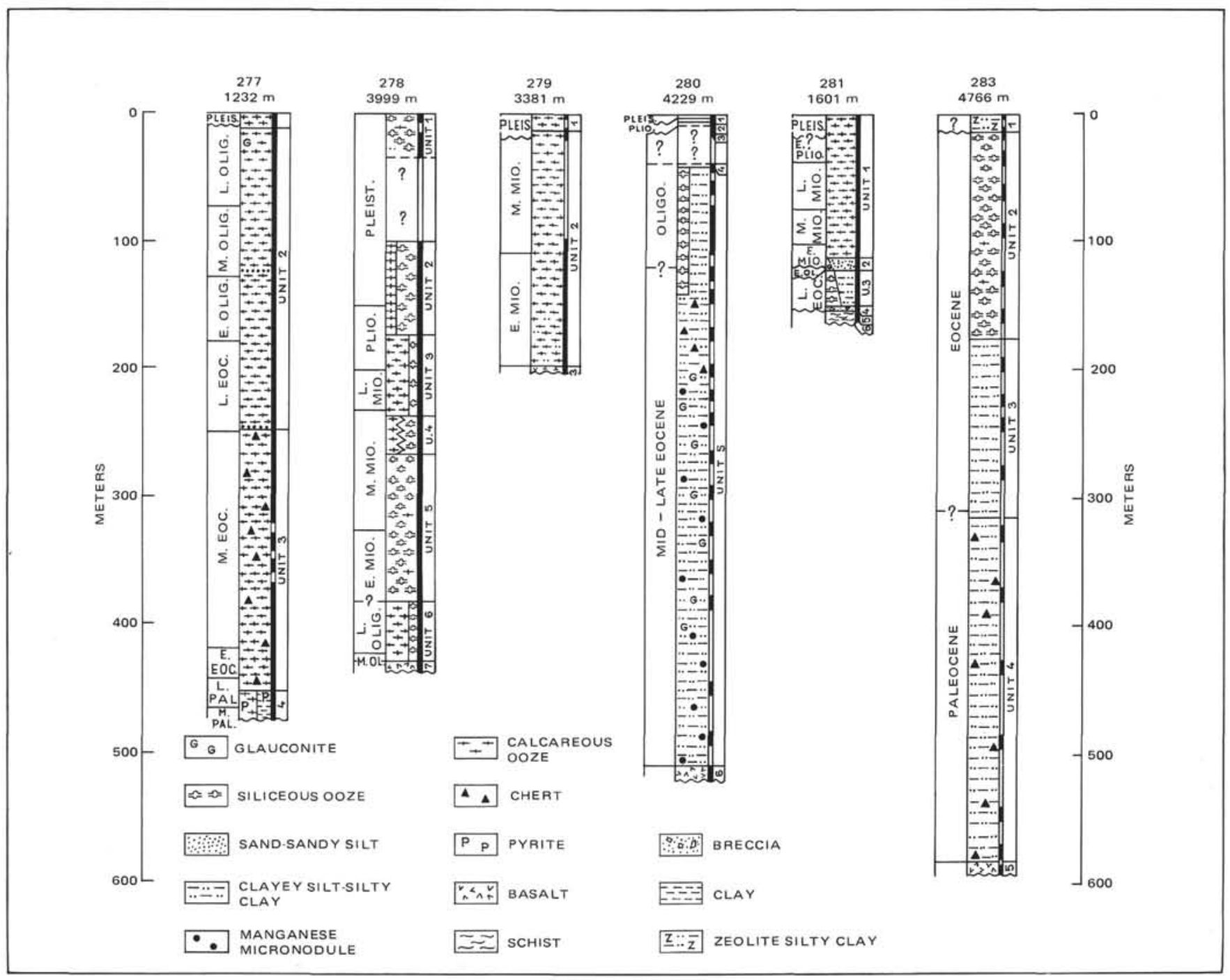

Figure 2. Siliceous microfossil-bearing sediments of drilling sites in the Southwest Pacific Ocean, Leg 29, Deep Sea Drilling Project.

climatological and ecological inferences can be drawn only on the few species still living. It should be stressed, however, that even these are not necessarily unchanged as to their ecology.

The upper Eocene-lower Oligocene assemblages are characterized by a great variety of forms and species, suggesting rather favorable environmental conditions. All the assemblages comprise autochthonous, wellpreserved, oceanic planktonic forms; neritic, littoral, brackish, nor fresh-water species were found. Planktonic species of large size indicate the lack of strong currents and favorable conditions of oxygenation. The presence of Stephanopyxis, Trinacria, Triceratium, Hemiaulus, Coscinodiscus symbolophorus, and C. radiatus, indicate a subtropical climate and optimal conditions.

A substantial climatic or physicochemical change is indicated at the Eocene-Oligocene boundary. A significant proportion of the late Eocene species becomes extinct, and a number of new species appear. The size of the species that cross the boundary generally decreases, although it is highly variable. This may be due to decreasing temperature, oxygen supply, or other ecological factors.

For paleogeographic comparison purposes, the following works were referred to: Greville (1861-1866), Schmidt's Atlas (1874-1959), Grunow (1884), Grove and Sturt (1886-1887), Pantocsek (1886-1905), Reinhold (1937), Jousé (1955), Kanaya (1957), Strelnikova (1960), Paramonova (1964), and Gleser and Posnova (1964). In quantitative terms, the Leg 29 microflora shows close affinities with those of the upper Eocene of Oamaru, New Zealand, Barbados, and Mt. Diablo of California. Several identical species have also been recorded from the Soviet Union (E. Ukraine, W. Kazakhstan, W. Siberia, the Caucasus, and the Urals); however, the number of identical species is lower than in the Eocene.

\section{SYSTEMATIC PALEONTOLOGY, FLORAL REFERENCE}

The diatoms, archaeomonads, and silicoflagellates of Sites 280, 281, and 283 were mainly determined and systematized on the basis of the 
TABLE 1

Distribution of Late Eocene and Early Oligocene Diatomaceae, Archaeomonadaceae, and Silicoflagellatae in Samples from DSDP Leg 29, Sites 280A, 281, 283

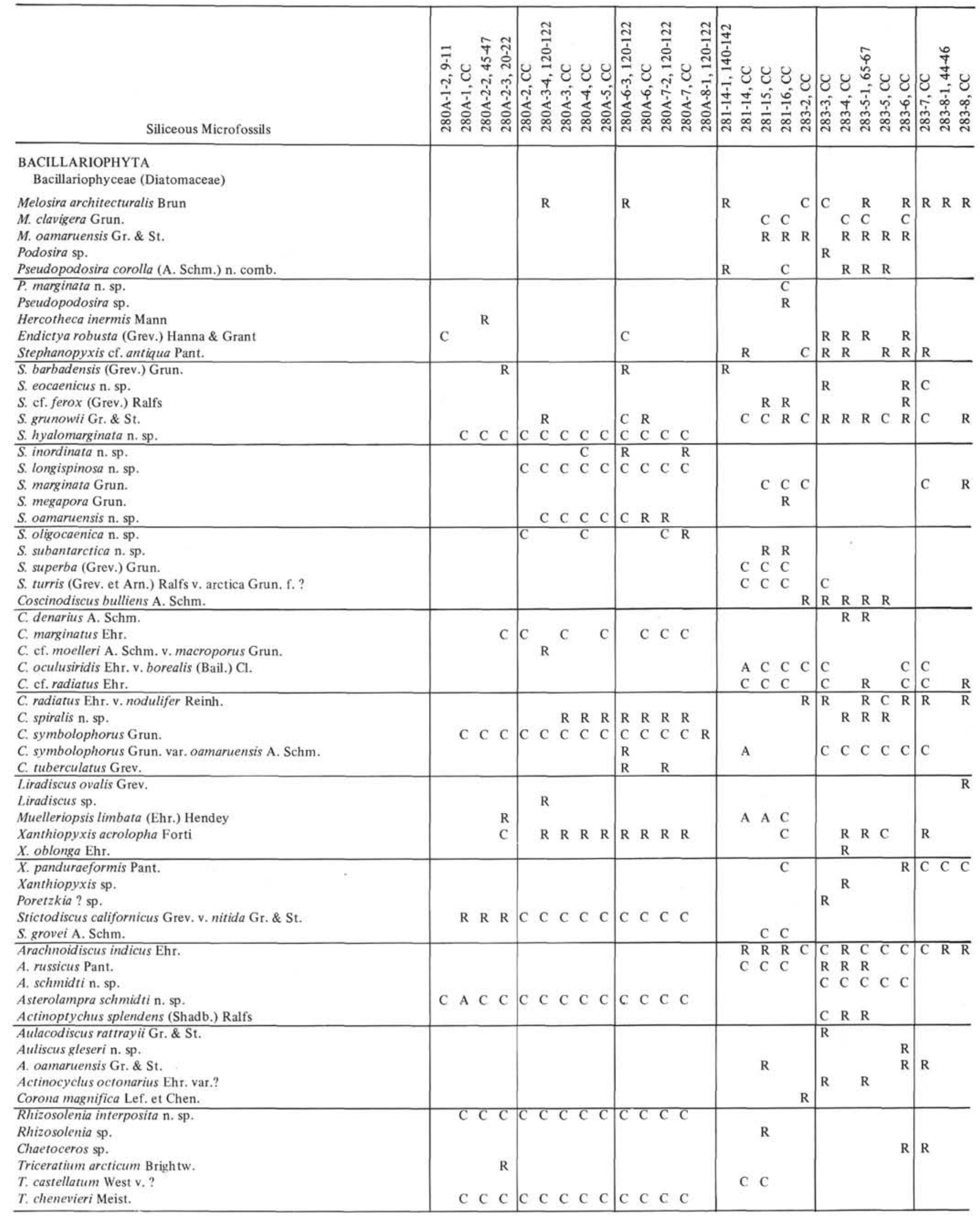


TABLE 1 - Continued

Siliceous Microfossils
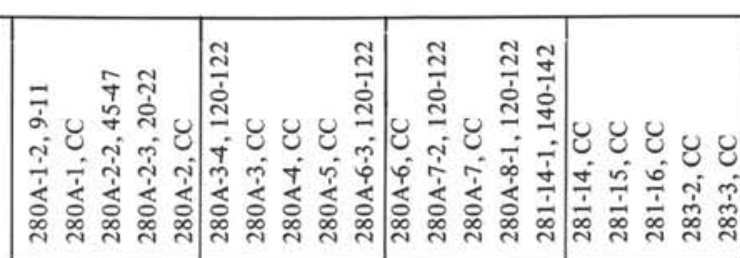

T. crenulatum Gr. \& St.

T. morlandii Gr. \& St.

T. oamaruense $\mathrm{Gr}$. \& $\mathrm{St}$.

$T$. oamaruense $\mathrm{Gr}$. \& St. v. sparsim punctata $\mathrm{Gr}$.

T. pulvinar A. Schm.

Biddulphia fimbriata Grev.

B. rigida $\mathrm{A}$. Schm.

Cerataulus pacificus $\mathrm{n}$. sp.

Cerataulina praebergoni $\mathrm{n}$. sp.

Hemiaulus caracteristicus n. sp.

H. incisus $\mathrm{n}$. sp.

H. polymorphus Grun. var.?

H. polymorphus Grun.

Trinacria excavata Heib.

T. simulacrum $\mathrm{Gr}$. \& St.

Pterotheca aculeifera Grun.

P. danica Grun.

Pyrgupyxis eocena Hendey

P. gracilis (Temp. et Forti) Hendey v. buccinalis (Forti) Hendey

P. gracilis (Temp. et Forti) Hendey v. saratoviana (Pant.) Hendey

P. johnsoniana (Forti) Hendey

$P$. johnsoniana (Forti) Hendey v. intermedia (Temp. et Forti) Hendey

Acanthodiscus rugosus Pant.

Goniothecium odontella Ehr.

Stephanogania cf. polyacantha Forti

Pseudorutilaria monile Gr.\& St.

Kisseleviella carina Shesh.

Rouxia rouxioides (Schrader) n. comb.

\section{CHRYSOPHYTA}

Archaeomonadaceae

Archaeomonas dubia Defl.

A. oamaruensis Defl.

A. ovalis Defl.

A. reticulosa Defl.

Archaeosphaeridium armatum n. sp.

Pararchaeomonas decorata n. sp.

P. (?) rigaudae $\mathrm{Rampi}$

Silicoflagellatae

Dictyocha deflandrei Freng.

D. fibula Ehr.

D. hexacantha Schulz

Hannaites quadria Mandra

Mesocena apiculata (Schulz) Hanna

M. oamaruensis Schulz

M. oamaruensis Schulz v, quadrangula Schulz

Naviculopsis biapiculata (Lemm.) Freng.

N. biapiculata (Lemm.) Freng. v. constricta (Schulz) Gleser

N. biapiculata (Lemm.) Freng. v. minor (Schulz) Gleser

N. trispinosa (Schulz) Gleser

\section{PORIFERA}

Spicules (different)

Note: $\mathrm{A}=$ abundant ? $=$ common $? \mathrm{R}=$ rare.

works of Proshkina-Lavrenko (1949), Deflandre (1969), and Gleser (1966). Description is given only for those species which could not be defined on the basis of the literature. Within the genera, the new and already known taxa are discussed in alphabetical order. The holotypes of new taxa are in the collection of the author at the Hungarian Geological Survey (Budapest, XIV, Nepstadion ut 14). The paratypes will be deposited in the collection of Dr. Friedrich Hustedt, in the "Institut fur Meeresforschung" Bremenhaven, Germany.
The undetermined but significant species were numbered and illustrated and will be published in a following work. From the siliceous sediments of the above-mentioned sites 42 genera, 108 species, and their variants were determined. Nineteen new species and two new combinations are included. The occurrence and frequency of the known taxa are given in Tables 1, 2, and 3.

Synonyms are given only in cases where the valid name of the taxon is changed or where the cited publication leaves it unmentioned. 
TABLE 2

Occurrence Ranges of Late Eocene and Early Oligocene Diatomaceae, Archaeomonadaceae, and Silicoflagellatae in Samples from DSDP Leg 29, Holes 280A and 281

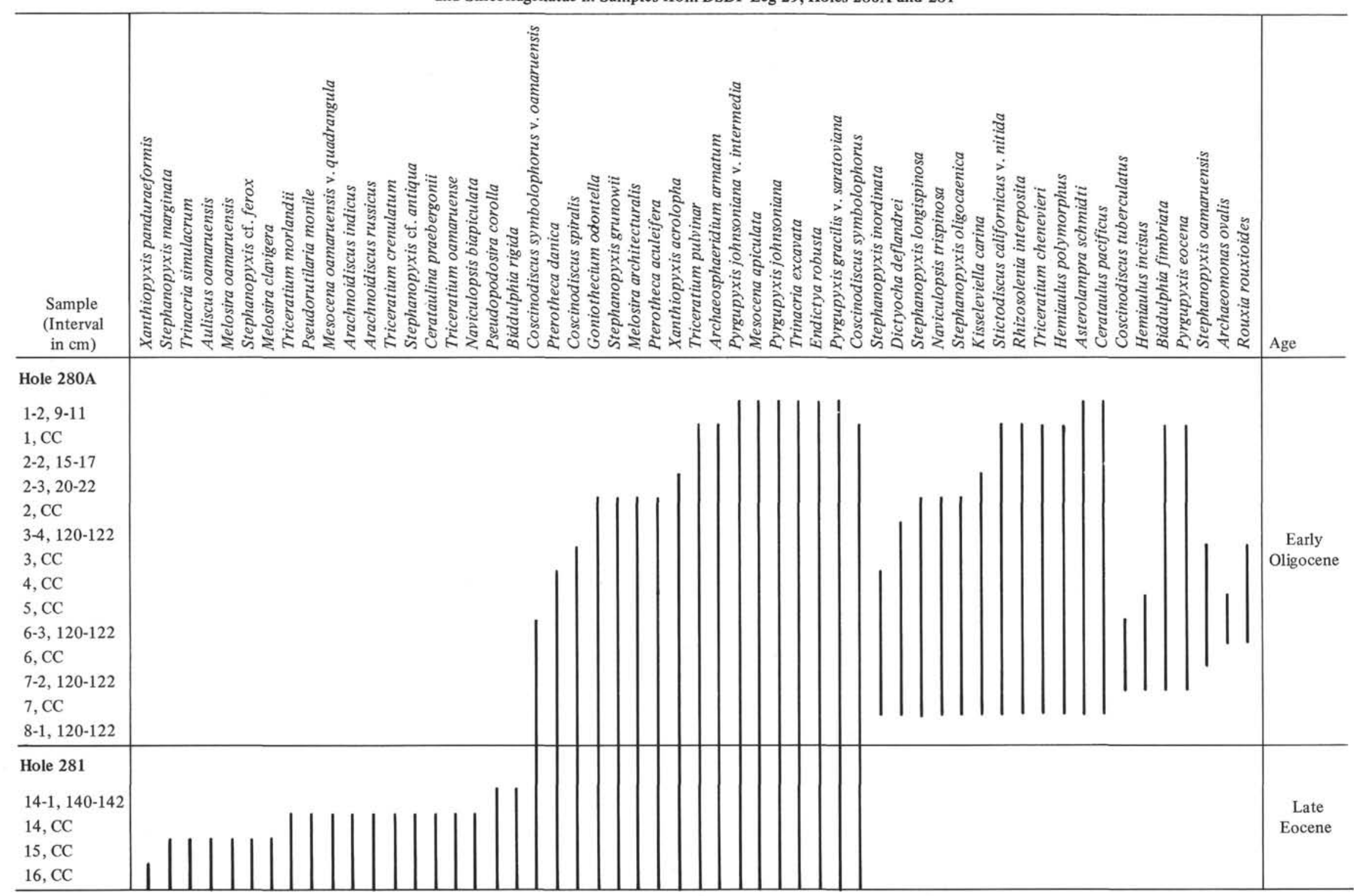


TABLE 3

Occurrence Ranges of Late Eocene and Early Oligocene Diatomaceae, Archaeomonadaceae, and Silicoflagellatae in Samples from DSDP Leg 29, Holes 280A and 283

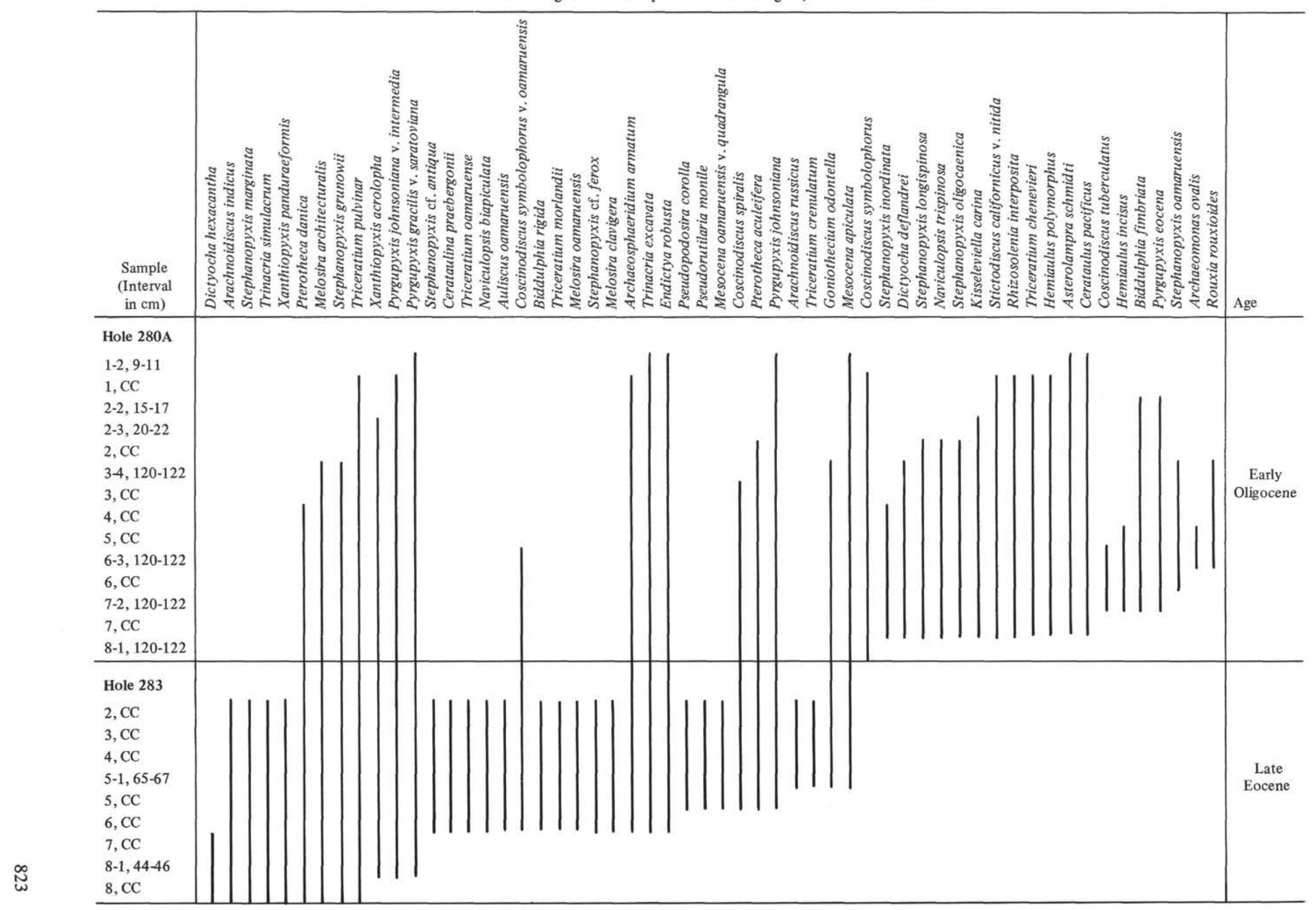

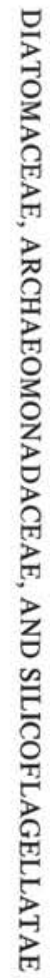




\section{HAJÓS}

Most of the species are of marine planktonic origin. Fresh-water or brackish species were not found.

The taxa-and even the longitudinal forms-may be placed in the orders Centrales Schutt and Mediales Jousé et Proshkina-Lavrenko. The order of Pennales is represented only by the species Rouxia rouxioides with a short, rudimentary raphe.

Age in the description of species means occurrence in the examined strata, and not chronostratigraphic range.

The list of microfossils is not complete because of the abundance of species and specimens and the short time available for this study. Only well-preserved taxa of characteristic morphology are described.

\section{BACILLARIOPHYCEAE}

(Diatomaceae)

Genus MELOSIRA Agardh, 1824

Melosira architecturalis Brun, 1892

(Plate 1, Figures 5, 6)

Description: Brun (1892), in Schmidt's Atlas (1874-1959), pl. 177, fig. 49, 50; Gleser (1969), p. 68, pl. 4, fig. 3.

Synonym: Cyclotella hannae Kanaya (1957), p. 82-84, pl. 3, fig. 1014.

Discussion: Seemingly this species is larger and more common in the late Eocene as it is in early Oligocene sediments.

Melosira clavigera Grunow, 1882

(Plate 1, Figures 3, 4; Plate 2, Figures 3, 4)

Grunow (1882), in Schmidt's Atlas (1874-1959), pl. 74, fig. 13-15, pl. 175, fig. 21-24; Pantocsek (1886), v. 1, p. 46; Van Heurck (18801885), pl. 91. fig. 1, 2.

\section{Melosira oamaruensis Grove and Sturt, 1887}

(Plate 1, Figures 1, 2)

Description: Grove and Sturt (1886-1887), p. 145, pl. 13, fig. 48, 49. Occurrence: Only in late Eocene sediments.

\section{Genus PODOSIRA Ehrenberg, 1840}

\section{Podosira sp. Hajós}

Description: Highly vaulted valves with thick wall, ornate by radiated reticulate pattern.

Dimension: Diameter $60 \mu \mathrm{m}$.

Occurrence: DSDP Leg 29, Sample 283-3, CC.

Age: Late Eocene.

Discussion: They look identical to Podosira sp. in Paramonova (1964), p. 239, pl. 1, fig. 6 a, b, from W. Siberia, early Eocene-late Eocene.

\section{Genus PSEUDOPODOSIRA Jousé, 1949}

\section{Pseudopodosira corolla (A. Schmidt) n. comb. Hajós} (Plate 1, Figures 9, 10)

Synonym: Podosira corolla A.S. in Schmidt's Atlas (1874-1959), pl. 140, fig. 11, 12 from Oamaru. Podosira aff. corolla A.S. in Paramonova (1964), p. 239, pl. 1, fig. 5, from W. Siberia.

Discussion: Our specimens look like those described and illustrated by Kanaya (1957), p. 118, pl. 8, fig. 15-17, as Hercotheca sp. a; occurrences in samples of Mt. Diablo.

Age: Late Eocene

Pseudopodosira marginata n. sp. Hajós

(Plate 1, Figures 7, 8; Holotype: Figure 7)

Derivation of name: marginatus (latin) = marginate

Diagnosis and description: The margin of the valve is hyaline and punctuated in the form of concentric rings with 12-14 small pores per $10 \mu \mathrm{m}$ arranged in quincunx pattern. The surface of the valve is undulated and vaulted. On the outer side of the projecting part of the valve radial ribs, on the inner side dentiform structures occur every 6 per $10 \mu \mathrm{m}$. The central part of the valve is depressed.

Dimension: Diameter 22-25 $\mu \mathrm{m}$.

Holotype: Prep. 3696/1, HGS.

Type locality: DSDP Leg 29, Sample 281-16, CC.

Type level: Late Eocene.

Occurrence: Identical with the type locality.
Pseudopodosira sp. Hajós (No illustration)

Description: It seems to be identical with Pseudopodosira bella Posnova and Gleser in Gleser and Posnova (1964), p. 61, pl. 1, fig. 2, text-fig. 1, 2. occurring in late Eocene sediments of W. Kazakhstan, USSR.

Age: Late Eocene.

Genus HERCOTHECA Ehrenberg, 1844 (1845)

Hercotheca inermis Mann, 1925

(Plate 25, Figures 3, 4)

Description: Mann (1925), p. 82, 83, pl. 18, fig. 1, 2.

Age: Early Oligocene.

Genus ENDICTYA Ehrenberg, 1844 (1845)

Endictya robusta (Greville) Hanna and Grant, 1926

(Plate 4, Figures 5-7; Plate 19, Figures 1, 2)

Description: Hanna and Grant (1926), p. 144, pl. 16, fig. 2, 3; Greville (1861-1866), v. 14, p. 3, pl. 1, fig. 8 as Coscinodiscus robustus. Age: Late Eocene-early Oligocene.

Genus STEPHANOPYXIS Ehrenberg, 1844 (1845)

Stephanopyxis ef. antiqua Pantocsek, 1892, 1905

(Plate 5, Figures 1, 2, 6-8)

Description: Pantocsek (1892), pl. 19, fig. 28 (1905), v. 3, p. 96, from Kusnetzk, USSR.

Age: Late Eocene.

\section{Stephanopyxis barbadensis (Greville) Grunow, 1884}

(No illustration)

Description: Grunow (1884), p. 91; Greville (1861-1866), v. 13, p. 3, 4. pl. 1, fig. 11, as Cresswellia barbadensis from Barbados. Illustrated in Schmidt's Atlas. pl. 130, fig. 6-10, from Oamaru.

Age: Late Eocene-early Oligocene.

\section{Stephanopyxis eocaenica n. sp. Hajós \\ (Plate 4, Figures 3, 4; Holotype)}

Derivation of name: eocaenicus (latin) $=$ of Eocene age.

Diagnosis and description: The valve slightly vaulted with areolae arranged in irregular tangential rows. Towards their margin the areolae appear to decrease in size, 4-5 areolae for each $10 \mu \mathrm{m}$ near the center. On the surface of the valve, at a distance of about $8-10 \mu \mathrm{m}$ from the margin a crown of long spines is seen. The spines are strong and long.

Dimension: Diameter 55-66 $\mu \mathrm{m}$

Holotype: Prep. 3756/1 HGS.

Type locality: DSDP Leg 29, Sample 283-6, CC, holotype.

Type level: Late Eocene.

Occurrences: DSDP Leg 29, Samples 283-3, CC; 283-6, CC; 283-7, $\mathrm{CC}$

\section{Stephanopyxis ef. ferox (Greville) Ralfs, 1861}

$$
\text { (Plate 3, Figure 7) }
$$

Description: In Pritchard (1861), Infus, p. 826, pl. 5, fig. 75; Grunow (1884), p. 89, 90; Greville (1861-1866), v. 7, pl. 8, fig. 19 as Cresswellia ferox.

Age: Late Eocene.

Stephanopyxis grunowii Grove and Sturt, 1888

(Plate 3, Figures 3, 4; Plate 4, Figures 1, 2)

Description: Schmidt's Atlas (1874-1959), pl. 130, fig. 1-5, from Oamaru.

Age: Late Eocene-early Oligocene.

Stephanopyxis hyalomarginata n. sp. Hajós

(Plate 19, Figures 11, 12; Holotype)

Derivation of name: hyalomarginatus (latin) $=$ after the large hyaline margin of the valve.

Diagnosis and description: Valve with large hyaline margin of $3 \mu \mathrm{m}$. The areolae are arranged in quincunx pattern. The inner wall of the valve finely punctuated. On the margin stout spines are seen; their 
number changes from about 11 to 18 . It is similar to $S$. superba, but its structure is finer, the areolae are denser.

Dimension: Diameter $42-45 \mu \mathrm{m}$.

Holotype: Prep. 3554/1 HGS.

Type locality: DSDP Leg 29, Sample 280A-7-1, 120-122 cm.

Type level: Early Oligocene.

Occurrences: DSDP Leg 29, Samples 280A-1, CC, 280A-7, CC; $280 \mathrm{~A}-6-3,120-122 \mathrm{~cm}$.

\section{Stephanopyxis inordinata n. sp. Hajós}

(Plate 20, Figures 4, 5; Holotype)

Derivation of name: inordinatus (latin) = irregular.

Diagnosis and description: On the central part of the valve the areolae are irregularly arranged and of irregular shape, about 2-3 to each $10 \mu \mathrm{m}$. Towards the margin smaller areolae are arranged in quincunx pattern, about 4-5 to every $10 \mu \mathrm{m}$. The inner part of the wall finely punctuated. The spines are small at the margin, their number is changing.

Dimension: Diameter 56-60 $\mu \mathrm{m}$.

Holotype: Prep. 3550/1 HGS.

Type locality: DSDP Leg 29, Sample 280A-6-3, 120-122 cm.

Type level: Early Oligocene.

Occurrences: DSDP Leg 29, Samples 280A-4, CC; 280A-7, CC.

Discussion: Our species is similar to Schmidt's Atlas, (1874-1959), pl. 123, "Oran, Figure 22, fraglich, ob sp. n.?" Our specimens are better arranged towards the margin.

\section{Stephanopyxis longispinosa n. sp. Hajós}

(Plate 20, Figures 1-3; Holotype)

Derivation of name: longispinosus (latin) $=$ after the long marginal spines.

Diagnosis and description: The valve is strongly vaulted with a margin of $1-2.5 \mu \mathrm{m}$ width. The surface of the valve is decorated by areolae arranged in quincunx pattern. The inner part of the wall is finely punctuated. On the central part of the valve $2-4$ areolae are in each $10 \mu \mathrm{m}$, the dimension of the areolae is decreasing toward the margin. The marginal spines are stout, $20-25 \mu \mathrm{m}$ long, their number varies from 7 to 12 . In literature such a Stephanopyxis species with long spines was not mentioned.

Dimension: Diameter 50-55 $\mu \mathrm{m}$

Holotype: Prep. 3530/1 HGS.

Type locality: DSDP Leg 29, Sample 280A-3-4, 120-122 cm.

Type level: Early Oligocene.

Occurrences: DSDP Leg 29, 280A-2, CC, 280A-7, CC; 280A-6-3, $120-122 \mathrm{~cm} ; 280 \mathrm{~A}-7-2,120-122 \mathrm{~cm}$.

\section{Stephanopyxis marginata Grunow, 1884}

(Plate 2, Figures 5, 6; Plate 3, Figures 5, 6)

Description: Grunow (1884), p. 90, pl. 5, fig. 17.

Synonym: Stephanopyxis grossecellulata Pantocsek, 1886, v. 1, p. 44, pl. 20, fig. 180, from Hungary, St. Péter.

Age: Late Eocene.

\section{Stephanopyxis megapora Grunow, 1884}

(Plate 3, Figures 1, 2)

Description: Grunow (1884), p. 89, pl. 5, fig. 24 a, b.

Age: Late Eocene.

Stephanopyxis oamaruensis n. sp. Hajós

(Plate 19, Figures 5-8; Holotype, Figures 7, 8)

Derivation of name: After the locality of Oamaru, New Zealand.

Diagnosis and description: The valve is strongly vaulted, decorated with stout spines. The areolae are arranged in quincunx pattern, their number varies between 6 to 7 in each $10 \mu \mathrm{m}$. It is identical with Schmidt's Atlas (1874-1959). Plate 130, Figure 29, "Oamaru," New Zealand.

Dimension: Diameter $28-35 \mu \mathrm{m}$, the wall is $10-15 \mu \mathrm{m}$ high.

Holotype: Prep. 3530/1 HGS.

Type locality: DSDP Leg 29, Sample 280A-3-4, 120-122 cm.

Type level: Early Oligocene.

Occurrences: DSDP Leg 29, Samples 280A-6-3, 120-122 cm; 280A$7-2,120-122 \mathrm{~cm} ; 280 \mathrm{~A}-3, \mathrm{CC} ; 280 \mathrm{~A}-4, \mathrm{CC}, 280 \mathrm{~A}-5, \mathrm{CC} ; 280 \mathrm{~A}-6, \mathrm{CC}$.
Stephanopyxis oligocaenica n. sp. Hajós

(Plate 19, Figures 3, 4; Holotype)

Derivation of name: (latin) $=$ of Oligocene age.

Diagnosis and description: The form is relatively small, the upper and lower valve are differently vaulted. On the surface of the valve the areolae are arranged in quincunx pattern, 4 in each $10 \mu \mathrm{m}$. The spines on the surface of the valves are irregularly arranged and of different length. In literature no similar form was mentioned. For the long spines it is a very characteristic form.

Dimension: Diameter 25-30 $\mu \mathrm{m}$.

Holotype: Prep. 3554/1 HGS.

Type locality: DSDP Leg 29, Sample 280A-7-2, 120-122 cm.

Type level: Early Oligocene.

Occurrences: DSDP Leg 29, Samples 280A-2, CC; $280 \mathrm{~A}-4$, CC; $280 \mathrm{~A}-7, \mathrm{CC}$

\section{Stephanopyxis subantarctica n. sp. Hajós}

(Plate 5, Figures 6-8; Holotype)

Derivation of name: subantarcticus (latin) $=$ after the type locality.

Diagnosis and description: The cells are large, slightly vaulted, the margin of the valve is $4 \mu \mathrm{m}$ wide surrounded by a hyalomargin and a ring of 4 to 5 unequal areolae. The areolae of the valve are arranged in quincunx pattern, $2.5-3$ in each $10 \mu \mathrm{m}$, decreasing toward the margin. The inner part of the wall is finely punctuated.

Dimension: Diameter 132-140 $\mu \mathrm{m}$.

Holotype: $3677 / 1$ HGS.

Type locality: DSDP Leg 29, Sample 281-15, CC.

Type level: Late Eocene.

Occurrence: DSDP Leg 29, Sample 281-16, CC.

Discussion: This species, showing a close affinity with Stephanopyxis turris var. antarctica Grunow, has a flat, slightly constricted valve. The marginal areolae are irregular, constricted, and without strong spines. The cells are, however, larger, more flattened with irregular, constricted marginal areolae.

Stephanopyxis superba (Greville) Grunow, 1884

(Plate 1, Figures 11-13)

Synonym: Cresswellia superba Greville (1865), v. 9, pl. 8, fig. 3-5. Description: Grunow (1884), p. 91.

Age: Late Eocene.

\section{Stephanopyxis turris (Greville and Arnott) Ralfs var. arctica Grunow, forma?}

(Plate 3, Figures 8, 9)

Description: Grunow (1884), p. 89, pl. 5, fig. 21, as Stephanopyxis turris var. arctica "änlich der var. intermedia, aber mit noch grösseren Maschen, und meist nur wenigen Stacheln."

Age: Late Eocene.

\section{Stephanopyxis sp. Hajós \\ (Plate 19, Figures 9, 10)}

Description: Similar to Stephanopyxis megapora except for the hyaline margin and the much smaller areolae around the margin. Age: Early Oligocene.

\section{Genus COSCINODISCUS Ehrenberg, 1838}

\section{Coscinodiscus bulliens A. Schmidt, 1878}

(Plate 6, Figures 5, 6)

In Schmidt's Atlas (1874-1959), pl. 61, fig. 11, 12. Age: Late Eocene.

\section{Coscinodiscus denarius A. Schmidt, 1878}

(Plate 7, Figures 4, 5)

In Schmidt's Atlas (1874-1959), pl. 57, figs. 20-21, from Barbados, Springfield. Similar to 1.c. pl. 138, fig. 6, Oamaru, sp. n.? Description: Hustedt (1927-1930), v. 1, p. 399-400, fig. 210. Age: Late Eocene.

\section{Coscinodiscus marginatus Ehrenberg, 1843}

(Plate 20, Figures 9, 10)

Description: Hustedt (1927-1930), v. 1, p. 416, fig. 223.

Age: Early Oligocene. 
Coscinodiscus ef. moelleri A. Schmidt var. macroporus Grunow, 1884 (Plate 20, Figures 13, 14)

Description: Hustedt (1927-1930), v. 1, p. 395, fig. 206, Grunow (1884), p. 84 , pl. 4 , fig. 25 .

Discussion: Specimens are much smaller as by Paramonova (1964), p. 239, pl. 5, fig. 4a, b, published from NW Siberia. Early Oligocene. Age: Early Oligocene.

Coscinodiscus oculusiridis Ehrenberg var. borealis (Bailey) Cleve, 1883 (Plate 4, Figures 10, 11)

Description: Hustedt (1927-1930), v. 1, p. 456, fig. 253 .

Age: Late Eocene.

Coscinodiscus cf. radiatus Ehrenberg, 1839

(Plate 4, Figures 12-14; Plate 5, Figures 3-5)

Description: Hustedt (1927-1930), v. 1, p. 420-421, fig. 225.

Discussion: It is similar to the form published by Kanaya from California (1957), p. 91-93, pl. 5, fig. 4a, b.

Age: Late Eocene.

Coscinodiscus radiatus Ehrenberg var. nodulifer Reinhold, 1937 (Plate 4, Figures 8, 9; Plate 6, Figures 3, 4)

Description: Reinhold (1937), p. 100-101, pl. 8, fig. 6, from E. Java. Age: Late Eocene.

Coscinodiscus spiralis n. sp. Hajós

(Plate 7, Figures 1-3; Holotype: Figures 1, 2)

Derivation of name: spiralis (latin) $=$ spiral

Diagnosis and description: The disc is flat, the margin is $1.5 \mu \mathrm{m}$ wide, bending downward, finely striated, 16 striae in each $10 \mu \mathrm{m}$. The central area is small, often asymmetrical, not in the midst of the disc. The surface of the disc is finely areolated with 12-13 areolae in each 10 $\mu \mathrm{m}$. The areolae are arranged in quincunx pattern, in radial and spiral rows. The species is similar to $C$. debilis Grove from Oamaru in Schmidt's Atlas, pl. 163, fig. 4. However in the latter species the radial rows are not spiral.

Dimension: Diameter 42-90 $\mu \mathrm{m}$.

Holotype: Prep. 3748/1 HGS.

Type locality: DSDP Leg 29, Sample 283-4, CC.

Type level: Late Eocene.

Age: Late Eocene-early Oligocene.

Occurrences: DSDP Leg 29, Samples 283-5, CC; 280A-6-3, 120-122 $\mathrm{cm} ; 280 \mathrm{~A}-3, \mathrm{CC} ; 280 \mathrm{~A}-7, \mathrm{CC}$.

Discussion: In the Oligocene sediments the forms are much smaller.

\section{Coscinodiscus symbolophorus Grunow, 1884}

(Plate 20, Figures 11, 12)

Description: Grunow (1884), p. 82, pl. 4, fig. 3-6.

Age: Early Oligocene.

Discussion: Common, but only small specimens with a diameter of $30-50 \mu \mathrm{m}$

\section{Coscinodiscus symbolophorus Grunow} var. oamaruensis A. Schmidt, 1888

(Plate 6, Figures 1, 2; Plate 10, Figure 1; Plate 20, Figure 15)

In Schmidt's Atlas (1874-1959), pl. 138, fig. 4, 5.

Age: Late Eocene-early Oligocene.

\section{Coscinodiscus tuberculatus Greville, 1861} (Plate 20, Figures 6-8)

Description: Greville (1861-1866), n. ser., v. 9, p. 42; pl. 4, fig. 6 . Type locality: "Barbados"-Oceanic formation; Kanaya (1957), p. 94 , pl. 6, fig. 6-8.

Age: Early Oligocene.

\section{Genus LIRADISCUS Greville, 1865}

\section{Liradiscus ovalis Greville, 1865}

(Plate 17, Figures 1, 2)

Description: Greville (1861-1866), v. 13, p. 5, pl. 1, fig. 15, 16. Age: Late Eocene.
Liradiscus sp. Hajós

(Plate 21, Figures 3, 4)

Description: Valve convex ellipsoidal with remarkable reticulation irregular in shape, and with some short spines. Found only in one sample.

Age: Early Oligocene.

Genus MUELLERIOPSIS Hendey, 1972

Muelleriopsis limbata (Ehrenberg) Hendey, 1972

(Plate 11, Figures 1-4)

Description: Hendey (1972), p. 87, pl. 1, 2.

Synonym: Pyxidicula limbata Ehrenberg (1844), p. 86; Pyxidicula, Stephanopyxis? limbata Ehrenberg, Muelleriella limbata Ehrenberg (1854), pl. 18, fig. 7, Van Heurck (1896), p. 435, fig. 160.

Age: Late Eocene-early Oligocene.

\section{Genus XANTHIOPYXIS Ehrenberg, 1844}

Xanthiopyxis cf. acrolopha Forti, 1912

(Plate 11, Figure 6; Plate 17, Figures 4, 10, 12; Plate 21, Figure 5)

Description: Forti (1912), v. 23, p. 84; Hanna (1927), p. 124, pl. 21, fig. 10,11 .

Age: Late Eocene-early Oligocene.

\section{Xanthiopyxis oblonga Ehrenberg, 1844 (1845)}

(Plate 17, Figure 11)

Description: Kanaya (1957), p. 116, pl. 8, fig. 12 a, b. Age: Late Eocene

Xanthiopyxis panduraeformis Pantocsek, 1886

(Plate 11, Figure 5; Plate 17, Figure 9)

Description: Pantocsek (1886), v. 1, p. 43 , pl. 29, fig. 297, from Szakal, Hungary.

Age: Late Eocene.

\section{Xanthiopyxis sp. Hajós}

(No illustration)

Description: Oval valve, with stout long spines.

Age: Late Eocene.

\section{Genus PORETZKIA Jousé, 1949}

Poretzkia? sp.

(Plate 17, Figure 3)

Description: The valve of this remarkable species is convex, flat, finely punctuated, with a central area; the ornamentation on its margin consists of prominent spines in coronal grouping. Occurrence in one sample only. The genus is doubtful, eventually a new one. Age: Late Eocene.

\section{Genus STICTODISCUS Greville, 1861}

Stictodiscus californicus Greville var. nitida Grove and Sturt, 1887 (Plate 21, Figures 1, 2)

Description: Grove and Sturt (1886-1887), v. 3, p. 66, pl. 5, fig. 7. Synonym: Stictodiscus nitidus Grove and Sturt (1888) in Schmidt's Atlas (1874-1959), pl. 131, fig. 7, 8; pl. 202, fig. 4, 5; pl. 451, figs. 5-7.

Age: Early Oligocene.

Discussion: All the l.c. figures are from Oamaru.

\section{Stictodiscus grovei A. Schmidt, 1890} (Plate 10, Figures 4-6)

In Schmidt's Atlas (1874-1959), pl. 147, fig. 5-7, from Oamaru. Age: Late Eocene.

Discussion: This is a transitional species between the genera Stictodiscus and Arachnoidiscus. 


\section{Arachnoidiscus indicus Ehrenberg, 1854}

(Plate 9, Figures 1, 2)

Description: Ehrenberg (1854), p. 165 (non vidi); Grove and Sturt (1887), p. 66, from Oamaru.

Age: Late Eocene.

\section{Arachnoidiscus russicus Pantocsek, 1892}

(Plate 10, Figures 2, 3)

Description: Pantocsek (1892), v. 3, pl. 15, fig. 226; (1905), p. 14. Age: Late Eocene.

Discussion: Its ornamentation is coarser, the areolae rare, larger, thus it cannot be ranged to the Arachnoidiscus indicus species. Identical with the form in Schmidt's Atlas (1874-1959), pl. 147, fig. 9 from Oamaru, "vielleicht zu Arachnoidiscus indicus zu rechnen."

\section{Arachnoidiscus schmidti n. sp. Hajós}

(Plate 8, Figures 1, 2; Holotype)

Derivation of name: Named in honor of A. Schmidt.

Diagnosis and description: The disc is flat, its surface is decorated by concentrically arranged dots, while divided by radial lines. These lines do not reach the central part of the disc, and between two long lines one longer and two shorter lines are seen. The radial lines are zigzagged. The center area is decorated by short ridges. The number of lines and ridges is variable.

Dimension: Diameter 110-115 $\mu \mathrm{m}$.

Holotype: Prep. 3748/1 HGS.

Type locality: DSDP Leg 29, Sample 283-4, CC.

Type level: Late Eocene.

Occurrences: DSDP Leg 29, Samples 283-5-1, 65-67 cm; 283-5, CC; 283-6, CC.

Discussion: The species is identical to Schmidt's Atlas pl. 147, fig. 1, originating from Oamaru, named Arachnoidiscus ehrenbergii Bail. var. oamaruensis, determined as "uncertain" by Schmidt. Regarding its ornamentation it shows closer affinity with $A$. russicus.

\section{Genus ASTEROLAMPRA Ehrenberg, 1844 (1845)}

\author{
Asterolampra schmidti n. sp. Hajós \\ (Plate 21, Figure 6; Holotype)
}

Derivation of name: Named in honor of A. Schmidt.

Diagnosis and description: The disc is flat, heavily decorated. The areolated surface is divided by radial, hyaline areas in several sections whose number varies between 6 and 9 . The areas are separated by radial ridges which are terminated in the center part of the disc forming a star-like pattern. The number of the sections is equal to the number of individual parts of the star, i.e., 6 to 9 , however, this number may reach 21 by further division. On the areolated part of the sections the areolae are arranged in quincunx pattern with 6-7 areolae in each $10 \mu \mathrm{m}$.

Dimension: Diameter 65-85 $\mu \mathrm{m}$

Holotype: Prep. $3550 / 1$ HGS.

Type locality: DSDP Leg 29, Sample 280A-6-3, 120-122 cm.

Type level: Early Oligocene. CC.

Occurrences: DSDP Leg 29, Samples 280A-1-2, 9-11 cm; 280A-1-7,

Discussion: This form is extraordinarily variable. It is similar to Schmidt's Atlas, pl. 137, fig. 6, "Oamaru, n. sp.?" and fig. 7, "Barbados, fraglich."

\section{Genus ACTINOPTYCHUS Ehrenberg, 1839}

\section{Actinoptychus splendens (Schadbolt) Ralfs, 1861} (Plate 9, Figure 6)

Description: In Pritchard (1861), Infus, p. 840. (non vidi); Hustedt (1927-1930), v. 1, p. 478-79, fig. 265.

Age: Late Eocene.

\section{Aulacodiscus rattrayii Grove and Sturt, 1887}

(Plate 9, Figure 3)

Description: Grove and Sturt (1886-1887), ser. 2, v. 3, p. 139-140, pl. 11, fig. 29, from Oamaru.

Age: Late Eocene.

Genus AULISCUS Ehrenberg, 1843 (1844)

\author{
Auliscus gleser n. sp. Hajós \\ (Plate 8, Figures 3-5; Holotype)
}

Derivation of name: Named in honor of S.I. Gleser, USSR.

Diagnosis and description: The disc is elliptic, flat. The ornamentation is a fine punctuation, arranged nearly cross-shaped, with a light bend at the center. Two protruding round pores are seen near the margin, at the two ends of the longitudinal axis.

Dimensions: Length $40 \mu \mathrm{m}$, width $32 \mu \mathrm{m}$.

Holotype: Prep. 3756/1 HGS.

Type locality: DSDP Leg 29, Sample 283-6, CC.

Type level: Late Eocene.

Discussion: Nearest from A. actinoptychoides Gleser, in Gleser and Posnova (1964), p. 54-56, pl. 3, fig. 1, 2. Gleser described this species from late Eocene and early Oligocene of Ukraine and Kazakhstan, USSR.

\section{Auliscus oamaruensis Grove and Sturt, 1887} (Plate 10, Figure 7)

Description: Grove and Sturt (1886-1887), ser. 2, v. 2, p. 10, 11, pl. 3., fig. 13, from Oamaru.

Age: Late Eocene.

\section{Genus ACTINOCYCLUS Ehrenberg 1837 (1838)}

\section{Actinocyclus octonarius Ehrenberg, 1838 var. ? \\ (Plate 9, Figure 4)}

Description: Hustedt (1927-1930), v. 1, p. 525-533, fig. 298.

Age: Late Eocene.

Discussion: It is not the typical form.

Genus CORONA Lefébure et Chenevière, 1938

Corona magnifica Lefébure et Chenevière, 1938

(Plate 8, Figures 6, 7)

Description: Lefébure et Chenevière (1938), p. 10, pl. 1, fig. 1, from Kamischev, USSR.

Age: Late Eocene.

Genus RHIZOSOLENIA Ehrenberg, 1841 (1843)

\section{Rhizosolenia interposita n. sp. Hajós}

(Plate 21, Figure 8; Holotype)

Derivation of name: Interpositus (latin) $=$ intermediate.

Diagnosis and description: Only apical extensions are found but they are common in all samples of the Oligocene sediments. This species shows close affinity with the Rhizosolenia curvirostris Jousé (1968), p. 19, pl. 3, fig. 1-3. The wall of the extension is $3 \mu \mathrm{m}$ thick, its diameter 11-12 $\mu \mathrm{m}$. To the end it becomes thinner and at last forms a beak. This beak is asymmetrical, bifurcate, separated in two parts. At Jousé's species the extension does not attenuate to the end and the beak is larger, greater. It is an intermediate form between $R$. cretacea n. sp. Hajós and $R$. curvirostris.

Dimension: Diameter $11-12 \mu \mathrm{m}$, the process is $100-110 \mu \mathrm{m}$ long.

Holotype: Prep. 3550/1 HGS.

Type locality: DSDP Leg 29, 280A-6-3, 120-122 cm.

Type level: Early Oligocene.

Occurrences: DSDP Leg 29, Sample 280A-2-3, 20-22 cm; 280A-1, $\mathrm{CC} ; 2, \mathrm{CC} ; 3, \mathrm{CC} ; 4, \mathrm{CC} ; 5, \mathrm{CC} ; 6, \mathrm{CC} ; 7, \mathrm{CC}$. 


\section{Rhizosolenia sp. Hajós}

(Plate 12, Figure 1)

Description: Long, small, apical extension at the base with a large valve, and very short spines. No complete valve has been observed. Age: Late Eocene.

\section{Genus CHAETOCEROS Ehrenberg, 1844 (1845)}

\section{Chaetoceros sp. Hajós \\ (Plate 9, Figure 5)}

Description: The cells form a chain. The surface of the valve is flat. From the valve's margin are rising several setae proceeding outwards at right angles to the axis of the chain. Two of the four strong setae start from the lower valve of a cell and intersect two rising ones from the upper valve of another cell.

Age: Late Eocene.

\section{Genus TRICERATIUM Ehrenberg, 1839 (1841)}

Triceratium arcticum Brightwell, 1853

Description: Proshkina-Lavrenko (1949-1950), v. 2, p. 168, pl. 94, fig. $5 a, b$.

Age: Early Oligocene

Triceratium castellatum West var.?, 1885 (Plate 12, Figures 4, 5)

In Schmidt's Atlas (1874-1959), pl. 88, fig. 16, from Barbados.

Synonym: Triceratium fractum Walker and Chase (1888) in Schmidt's Atlas, pl. 128, fig. 9, 10, Oamaru; $T$. castellatum West var. fracta Grunow in Schmidt's Atlas, pl. 167, fig. 7, 8, Oamaru; T. fractum Walker and Chase in Schmidt's Atlas, pl. 167, fig. 9, 10, Oamaru. Age: Late Eocene.

\section{Triceratium chenevieri Meister}

(Plate 21, Figures 9, 10)

In Strelnikova (1960), pl. 9, fig. 3, from USSR, late Eocene-early Oligocene.

Age: Early Oligocene.

Triceratium crenulatum Grove and Sturt, 1887

(Plate 13, Figures 1, 2)

Description: Grove and Sturt (1886-1887), ser. 2, v. 3, p. 7, pl. 2, fig. 3, 4, Oamaru, in Schmidt's Atlas (1874-1959), pl. 128, fig. 20, 21, Oamaru.

Age: Late Eocene.

\section{Triceratium morlandii Grove and Sturt, 1887}

(Plate 13, Figures 7, 8)

Description: Grove and Sturt (1886-1887), ser. 2, v. 3, p. 7, 8, pl. 2, fig. 5, Oamaru, in Schmidt's Atlas (1874-1959), pl. 128, fig. 5, 6, Oamaru, pl. 150, fig. 22, Oamaru.

Age: Late Eocene.

\section{Triceratium oamaruense Grove and Sturt, 1887}

$$
\text { (Plate 12, Figures 2, 3) }
$$

Description: Grove and Sturt (1886-1887), ser. 2, v. 3, p. 135, pl. 10, fig. 18, from Oamaru, in Schmidt's Atlas (1874-1959), pl. 128, fig. 2, from Oamaru.

Age: Late Eocene.

\section{Triceratium oamaruense Grove and Sturt} var. sparsimpunctata Grove, 1890

$$
\text { (Plate 12, Figures 6, 7) }
$$

In Schmidt's Atlas (1874-1959), pl. 159, fig. 4. Age: Late Eocene.

Triceratium pulvinar A. Schmidt, 1888

(Plate 12, Figures 8, 9; Plate 13, Figures 3, 4; Plate 14, Figures 1-8; Plate 21, Figures 11, 12)

In Schmidt's Atlas (1874-1957), pl. 126, fig. 8, pl. 168, fig. 7, from Oamaru.
Age: Late Eocene-early Oligocene.

Discussion: Remarkable and common form of all the samples of late Eocene and early Oligocene.

\section{Genus BIDDULPHIA Gray, 1821}

\section{Biddulphia fimbriata Greville, 1865}

(Plate 22, Figures 7, 8)

Description: Greville (1861-1866), ser. 14, p. 6, pl. 1, fig. 4, from Barbados.

Age: Early Oligocene.

\section{Biddulphia rigida A. Schmidt, 1888}

(Plate 13, Figures 5, 6)

In Schmidt's Atlas (1874-1957), pl. 120, fig. 1, 2, from Oamaru. Synonym: Biddulphia fistulosa Pantocsek (1892), v. 3, pl. 18, fig. 273; (1905), p. 21, from Kusnetzk, USSR.

Age: Late Eocene.

\section{Genus CERATAULUS Ehrenberg, 1843 (1844)}

Cerataulus pacificus n. sp. Hajós

(Plate 22, Figures 1-6; Holotype 1, 2)

Derivation of name: After the type locality.

Diagnosis and description: The cell is rounded with thick walls and variable ornamentation. The surface of the disc is decorated by areolae of different size and approximately radial arrangement and irregular form. The outward margin of the disc is bent downward, this part is 6$8 \mu \mathrm{m}$ high. At the two ends of a diagonal line two protruding pores are seen. At the center of the valve are two strong spines. The pores of the areolae show a fine, complex inner structure.

Dimension: Diameter 36-85 $\mu \mathrm{m}$.

Holotype: Prep. 3503/1 HGS.

Type locality: DSDP Leg 29, 280A-1-1, 9-11 cm.

Type level: Early Oligocene.

Occurrences: DSDP Leg 29, Samples 280A-2-3, 20-22 cm; 280A-3$4,120-122 \mathrm{~cm} ; 280 \mathrm{~A}-6-3,120-122 \mathrm{~cm}-280 \mathrm{~A}-7-2,120-122 \mathrm{~cm} ; 280 \mathrm{~A}-1$, CC-280A-7, CC

Discussion: Similar to Cerataulus marginatus Grove and Sturt (1886-1887), ser. 2, v. 3, p. 135, pl. 11, fig. 21. This species shows two protruding pores as well, however its ornamentation consists of finer areolae.

\section{Genus CERATAULINA Peragallo, 1892}

\section{Cerataulina praebergonii n. sp. Hajós}

(Plate 14, Figure 13; Plate 15, Figures 5-7; Holotype: Figure 5)

Derivation of name: Conform to its similarity with the species $C$. bergonii Peragallo.

Diagnosis and description: The cylindric valve with an inner rodshaped statospore. The surface of the statospore is finely punctuated with scattered spicules. The wall of the valve is terminated in several hyaline filaments.

Dimension: Diameter $18 \mu \mathrm{m}$, length $55-65 \mu \mathrm{m}$, length of filaments 36-60 $\mu \mathrm{m}$, fragmented.

Holotype: Prep. 3756/1 HGS.

Type locality: DSDP Leg 29, Sample 283-6, CC.

Type level: Late Eocene.

Occurrences: Leg 29, 281-14, CC; 281-15, CC.

Discussion: Very similar to C. bergonii Peragallo (1892), v. 1, p. 103 , pl. 13, fig. 15, 16, in Hustedt (1927-1930), v. 1, p. 869-871, fig. 517, it is a species of the neritic plankton.

Genus HEMIAULUS Ehrenberg, 1844 (1845)

\section{Hemiaulus caracteristicus n. sp. Hajós (Plate 15, Figure 10; Holotype)}

Derivation of name: caracteristicus (latin) $=$ characteristic.

Diagnosis and description: Found only as a side view. The valve has a relatively long and narrow base of $8 \mu \mathrm{m}$ width, at both ends extremely long horns with long interior spine. The valve is roughly areolated becoming finer towards the end of the horns.

Dimensions: Diameter $85 \mu \mathrm{m}$, height of the horns $45 \mu \mathrm{m}$, height of the spines $10 \mu \mathrm{m}$. 
Holotype: Prep. 3748/1 HGS.

Type locality: DSDP Leg 29, Sample 283-4, CC.

Type level: Late Eocene.

Discussion: Illustrated in Schmidt's Atlas (1874-1959), pl. 142, fig. 12, Mors (Denmark) - "scheint Witt und mir eine neue Spezies zu sein."

Hemiaulus incisus n. sp. Hajós

(Plate 23, Figures 4-9; Holotype: Figures 6, 7)

Derivation of name: incisus (latin) $=$ incision.

Diagnosis and description: Valve lanceolated in outline, in the middle part flatly vaulted, with two long horns at both ends of the valve. At the base of the horns, on the valve incisions are seen. Areolae are coarse and scattered, becoming finer and parallel up to the end of the horns and spines.

Dimension: Diameter $22-45 \mu \mathrm{m}$, height $17-20 \mu \mathrm{m}$, length of the horns from the incision $50 \mu \mathrm{m}$, length of the spines $10-15 \mu \mathrm{m}$.

Holotype: Prep. 3550/1 HGS.

Type locality: DSDP Leg 29, Sample $280 \mathrm{~A}-6-3,120-122 \mathrm{~cm}$.

Type level: Early Oligocene.

Occurrences: DSDP Leg 29, 280A-7-2, 120-122 cm; 280A-5, CC.

Discussion: Similar to Hemiaulus kittonii Grunow (1884), p. 61, Schmidt's Atlas, pl. 142, fig. 2-8, 11. Mors.

Hemiaulus polymorphus Grunow, 1884, var.?

(Plate 15, Figures 11, 12)

Synonym: Hemiaulus polycystinorum var. mesolepta Grunow (1884).

Description: Grunow (1884), p. 65, pl. 2, fig. 43, from Barbados.

Age: Late Eocene.

Discussion: It differs from the characteristic forms, probably $H$. polymorphus $\mathrm{n}$. var. with long horns.

\section{Hemiaulus polymorphus Grunow, 1884} (Plate 23, Figures 2, 3)

Description: Grunow (1884), p. 66, pl. 2, fig. 43; ProshkinaLavrenko (1949-1950), v. 2, p. 185, pl. 71, fig. 2, 3.

Age: Early Oligocene.

\section{Genus TRINACRIA Heiberg, 1863}

Trinacria excavata Heiberg, 1863

(Plate 14, Figure 9; Plate 15, Figures 8, 9; Plate 23, Figure 1)

Description: Grunow (1884), p. 67. Franz Joseph Land, in Schmidt's Atlas (1874-1959), pl. 96, fig. 6-8; pl. 97, fig. 6-10, from Mors, Denmark.

Age: Late Eocene-early Oligocene.

Trinacria simulacrum Grove and Sturt, 1887 (Plate 15, Figures 1-4)

Description: Grove and Sturt (1886-1887), ser. 2, v. 3, p. 144; pl. 13, fig. 46, from Oamaru. Similar to Schmidt's Atlas (1874-1959), pl. 127, fig. 14.

Age: Late Eocene.

\section{Genus PTEROTHECA Grunow, 1881}

\section{Pterotheca aculeifera Grunow in Van Heurck, 1881} (Plate 16, Figures 6-8)

Description: Grunow in Van Heurck (1880-1885), pl. 83, bis. fig. 5, from Mors, Denmark, in Van Heurck (1896), p. 430, fig. 151.

Age: Late Eocene.

\section{Pterotheca danica Grunow in Van Heurck, 1881} (Plate 16, Figures 12-15)

Description: Grunow in Van Heurck (1880-1885), pl. 83, bis. fig. 7, 8, as Stephanogonia/Pterotheca?/danica from Mors, Denmark. Age: Late Eocene.
Genus PYRGUPYXIS Hendey, 1969

Pyrgupyxis eocena Hendey, 1969

(Plate 24, Figures 3-5, 8, 9)

Description: Hendey (1969), p. 3-5. fig. 1-4, from cores of South Atlantic Eocene.

Age: Early Oligocene.

\author{
Pyrgupyxis gracilis/Tempère and Forti/Hendey var. buccinalis/ \\ Forti/Hendey, 1969 \\ (No illustration)
}

Description: Hendey (1969), p. 5, Forti (1909), p. 26, pl. 2, fig. 6, Oamaru.

Age: Late Eocene.

\section{Pyrgupyxis gracilis/Tempère and Forti/Hendey var. saratoviana/ Pantocsek/Hendey, 1969 \\ (Plate 16, Figures 1-5)}

Description: Hendey (1969), p. 5, from South Atlantic Eocene core. Synonym: Hemiaulus? saratoviamus Pantocsek (1889), v. 2, p. 83, pl. 13, fig. 235, from Kusnetzk, USSR.

Age: Late Eocene-early Oligocene.

\section{Pyrgupyxis johnsoniana (Forti) Hendey, 1969}

(Plate 16, Figures 9-11, 16; Plate 24, Figures 6, 7, 10-12)

Description: Hendey (1969), p. 5.

Synonym: Pyxilla johnsoniana Greville in Forti (1909), p. 26, pl. 2, fig. 2, from Oamaru, non Pyxilla johnsoniana Greville (1865), v. 13, n. ser., p. 2, pl. 1, fig. 6 .

Age: Late Eocene-early Oligocene.

\section{Pyrgupyxis johnsoniana (Forti) Hendey var. intermedia/Tempère and Forti/Hendey, 1969 (Plate 24, Figures 1, 2)}

Description: Hendey (1969), p. 5, from South Atlantic core; Forti (1909), p. 26, pl. 2, fig. 3, 4, Barbados.

Age: Late Eocene-early Oligocene.

\section{Genus ACANTHODISCUS Pantocsek, 1892}

\section{Acanthodiscus rugosus Pantocsek, 1892} (Plate 17, Figures 5, 6)

Description: Pantocsek (1892), v. 3, pl. 11, fig. 180; (1905), p. 3, 4, from Kusnetzk, USSR.

Age: Late Eocene.

Discussion: This form is more plicate and vaulted than the species of Pantocsek. Possibly it is Xanthiopyxis.

\section{Genus GONIOTHECIUM Ehrenberg, 1844 (1845)}

Goniothecium odontella Ehrenberg, 1844

(Plate 17, Figure 13; Plate 25, Figures 1, 2)

Description: Jousé (1951), p. 60, pl. 5, fig. 1-7.

Age: Late Eocene-early Oligocene.

\section{Genus STEPHANOGONIA Ehrenberg, 1844 (1845)}

Stephanogonia cf. polyacantha Forti, 1913 (Plate 17, Figures 7, 8)

Description: in Hanna (1932), p. 218, pl. 16, fig. 8. Age: Late Eocene.

\section{Genus PSEUDORUTILARIA Grove and Sturt, 1886}

\section{Pseudorutilaria monile Grove and Sturt, 1886} (Plate 14, Figures 10-12)

Description: Grove and Sturt (1886), p. 324, pl. 18, fig. 7, 8, from Oamaru.

Age: Late Eocene. 
SILICOFLAGELLATAE

Kisseleviella carina Sheshukova, 1962

(Plate 25, Figures 5-9, 14)

Description: Sheshukova-Poretzkaya (1962), fig. 2a-g; p. 236-237, pl. 40 , fig. 6 a, b, v; pl. 41 , fig. $5 a, b, v$.

Age: Early Oligocene.

Genus ROUXIA Brun and Héribaud, 1893

Rouxia rouxioides (Schrader) n. comb. Hajós (Plate 25, Figures 10-13)

Description: Schrader (1969), p. 67-68, pl. 15, fig. 11 as Diploneis rouxioides, from Oamaru.

Age: Early Oligocene.

\section{ARCHAEOMONADACEAE}

Genus ARCHAEOMONAS Deflandre, 1932a

Archaeomonas dubia Deflandre, 1933, p. 84, fig. 10 (Plate 18, Figures 4, 5)

Age: Late Eocene.

Archaeomonas oamaruensis Deflandre, 1933, p. 85, fig. 15

(Plate 18, Figures 1-3)

Age: Late Eocene.

Archaeomonas ovalis Deflandre, 1933, p. 86, fig. 27

(Plate 25, Figures 15-16)

Age: Early Oligocene

Archaeomonas reticulosa Deflandre 1932b, p. 350, fig. 20-21 (Plate 18, Figures 13, 14)

Age: Late Eocene.

Genus ARCHAEOSPHAERIDIUM Deflandre 1932a

Archaeosphaeridium armatum n. sp. Hajós

(Plate 18, Figures 6-8; Holotype: 6, 7)

Derivation of name: armatus (latin) - armed.

Diagnosis and description: Globular cyst with large, rounded pore. Round the pore $2.5 \mu \mathrm{m}$ high thick wall. On the opposite side of the pores of the cyst 1-4 heavy, long spines are present. The surface of the cyst is simple, smooth, hyaline. It is similar to Archaeosphaeridium pachyceros Deflandre (1933), p. 88,89 , fig. 40,41 . The difference is that the number of spines, on the species under discussion, is lower; the spines are longer and occur on the opposite side of the cyst's pore.

Dimension: Diameter 20-24 $\mu \mathrm{m}$. Length of the spine $=30-60 \mu \mathrm{m}$. Holotype: $3756 / 1$ HGS.

Type locality: DSDP Leg 29, Sample 283-6, CC.

Type level: Late Eocene.

Occurrence: DSDP Leg 29, Sample 280A-2-3, 20-22 cm.

Age: Late Eocene-early Oligocene.

\section{Genus PARARCHAEOMONAS Deflandre, 1932a}

Pararchaeomonas decorata n. sp. Hajós (Plate 18, Figures 9, 10; Holotype)

Derivation of name: decoratus (latin) $=$ decorated.

Diagnosis and description: Globular cyst with large, rounded, projecting pore. The surface of the cyst is plicated. At the contact of the plicae are spines, similar to Pararchaeomonas? rigaudae Rampi 1969, in Deflandre (1969), fig. 4400, from Eocene. Kreyenhagen, California, USA, but our forms are ornamented.

Dimension: Diameter $25 \mu \mathrm{m}$.

Holotype: Prep. 3748/1. HGS.

Type locality: DSDP Leg 29, Sample 283-4, CC.

Age: Late Eocene.

$$
\begin{gathered}
\text { Pararchaeomonas (?) rigaudae Rampi, 1969, } \\
\text { in Deflandre 1969, fig. } 4400
\end{gathered}
$$

Age: Late Eocene.
Genus DICTYOCHA Ehrenberg, 1839

Dictyocha deflandrei Frenguelli, 1940, p. 65, fig. 14a, d. (non vidi)

In Gleser (1966), p. 244, pl. 12, fig. 13, 16; pl. 32, fig. 4. (Plate 25, Figure 18)

Age: Early Oligocene.

Dictyocha fibula Ehrenberg, 1839, p. 129 (non vidi) (Plate 18, Figures 15, 16)

In Gleser (1966), p. 24, pl. 13, fig. 6-9; pl. 14, fig. 1-9. Age: Late Eocene.

Dictyocha hexacantha Schulz, 1928

(No illustration)

Age: Late Eocene.

Genus HANNAITES Mandra, 1969

Hannaites quadria Mandra, 1969

(No illustration)

Age: Late Eocene.

Genus MESOCENA Ehrenberg, 1843

Mesocena apiculata (Schulz) Hanna, 1931

(Plate 18, Figure 18; Plate 25, Figure 17)

Age: Late Eocene-early Oligocene.

Mesocena oamaruensis Schulz, 1928 (No illustration)

Age: Late Eocene.

Mesocena oamaruensis Schulz var. quadrangula Schulz, 1928 (No illustration)

Age: Late Eocene.

Genus NAVICULOPSIS Frenguelli, 1940

Naviculopsis biapiculata (Lemmermann) Frenguelli, 1940 (Plate 18, Figure 20)

In Gleser (1966), p. 256, pl. 16, fig. 2-5.

Age: Late Eocene.

$$
\begin{gathered}
\text { Naviculopsis biapiculata (Lemmermann) Frenguelli } \\
\text { var. constricta (Schulz) Gleser (1966) } \\
\text { (Plate 18, Figure 21) }
\end{gathered}
$$

Age: Late Eocene.

\section{Naviculopsis biapiculata (Lemmermann) Frenguelli var. minor (Schulz) Gleser, 1966 (No illustration)}

Age: Late Eocene.

$$
\begin{gathered}
\text { Naviculopsis trispinosa (Schulz) Gleser } 1966 \\
\text { (Plate 25, Figure 19) }
\end{gathered}
$$

Age: Early Oligocene.

\section{PORIFERA}

Spicule I

(Plate 18, Figure 17)

Age: Late Eocene.

Spicule II

(Plate 18, Figure 19)

Age: Late Eocene. 


\section{STRATIGRAPHICAL OBSERVATIONS}

Paleontological determinations made possible the stratigraphical dating of late Eocene-early Oligocene sediments found in Hole 280A, Site 281, and 283, as well as the correlation of late Eocene sediments found at Sites 281 and 283. To this end, a diagram was constructed (Figure 3). On this curve $a$ marks the comparison of the number of species occurring in late Eocene samples of both Sites 281 and 283, and curve $b$ designates the percentage of species occurring in late Eocene samples of both Sites 281 and 283, related to the total species numbers, respectively.

Thus it became possible to correlate the diatom sediments of Site 281 of about 30 meters thickness with the diatom sediments of Site 283 of about 200 meters thickness. It may be stated from the diagram that a correlation of samples 281-14, CC with those of 283-3, CC and 4, CC, as well as those of Samples 281-15, CC and $16, \mathrm{CC}$ with Samples 283-5, CC and 6, CC is possible.

The microflora studies have not permitted the determination of standard or local biozones. In this region of the SW Pacific the lack of Oligocene sedimentation makes it impossible to determine the top of early Oligocene species ranges. On the other hand, the determination of the bottom of species ranges in the middle Eocene-early Eocene-Paleocene sediments was impossible because of the complete lack of siliceous microfloras. This disappearance downwards is rather sudden, although the sediment was unchanged clayey silt and silty clay; e.g., 283-8, CC yielded an invaluable amount of diatoms and Silicoflagellata, while 283-9-1 turned out to be barren. This absence of siliceous microfossils is either original, or brought about by dissolution during the sedimentation or during diagenesis.

The distribution of short-range and remarkably dominant species has been compared to that of the Californian diatom assemblage described by Kanaya (1957) which is characteristic of the late Eocene, as well as with the Silicoflagellata (Bukry and Foster, 1974), nannofossil (Edwards 1973), and planktonic foraminifera zones of paleogeographically related areas.

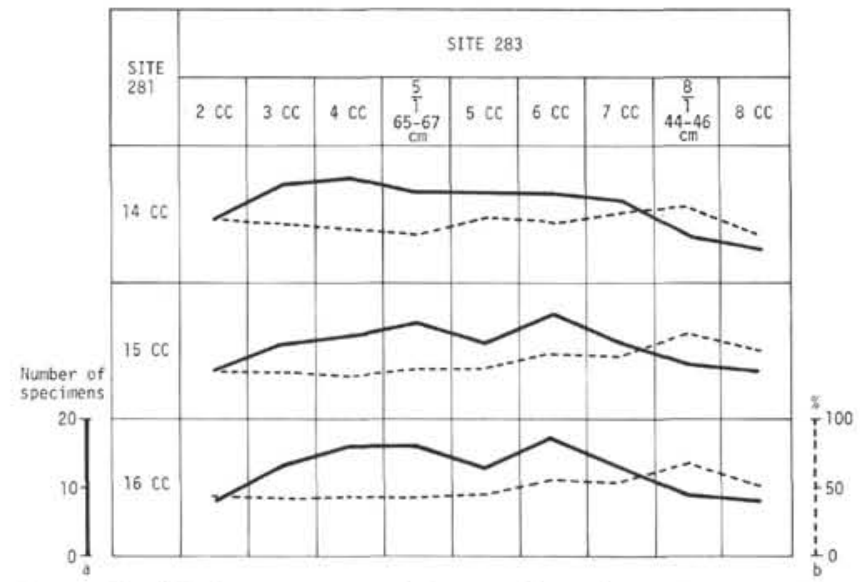

Figure 3. (a) Comparison of the number of species occurring in late Eocene samples of both Sites 281 and 283. (b) Diagram of the percentage of species occurring in late Eocene samples of both Sites 281 and 283, related to the total species numbers, respectively.
The species represented in Tables 1 and 3 as well as the occurrence in our samples of the zone marker species of the authors quoted above have been compared to the standard calcareous nannoplankton zones by Martini (1971, p. 741, 747). It could be stated that samples of Sites 281 and 283 may be correlated with Zones NP-18 and NP-19, while the samples of Hole 280A with Zone NP-22 of Martini (1971) (Figure 4).

\section{ACKNOWLEDGMENTS}

The author thanks the Deep Sea Drilling Project and in particular Dr. Terence Edgar, Chief Scientist, for having given her the opportunity of participating in Leg 29 of the D/V Glomar Challenger cruises, from Christchurch to Wellington, New Zealand. The writer thanks for the opportunity President Dr. J. Fülöp, Central Office of Geology, Budapest, Hungary and Director Dr. J. Konda, Hungarian Geological Survey, Budapest, Hungary. Many thanks are due to Professor Dr. M. Kretzoi, Hungarian Geological Survey, Budapest, for his helpful advice in problems of biostratigraphy.

The author thanks Dr. E. Dudich, chief scientist, Hungarian Geological Survey, for the critical review and translation of the manuscript and helpful suggestions.

Thanks are due to Dr. Katharina Perch-Nielsen, Geologisches Institut E.T.H. Sonnegg Str., Zürich, Switzerland, who took and sent me the scanning electron micrography from Sample 29-280A-5-1, 110-112 cm.

Thanks are due to Mrs. Ildikó Mihály, my technician, who prepared most of the microscope slides, assisted in drawing and photographic work, and mounted the plates. Finally, my sincere thanks to G. Chikán, geologist, and also to all other colleagues in the Hungarian Geological Survey, who contributed and helped in this work too.

\section{REFERENCES}

Bukry, D. and Foster, J.H., 1974. Silicoflagellate zonation of Upper Cretaceous to lower Miocene deep-sea sediment: J. Res. U.S. Geol. Surv., v. 2, p. 303-310.

Brun, J., 1893-1896. Notes sur quelques Diatomées miocénes: Le diatomiste, v. 2, p. 209-247.

Deflandre, G., 1932a. Archaeomonadaceae, une famille nouvelle de Protistes fossiles marins a loge siliceuse: C. R. Acad. Sci., v. 194, p. 1859-1861.

1932b. Note sur les Archaeomonadacées: Soc. Bot. France Bull., v. 79, p. 346-355.

1933. Seconde note sur les Archaeomonadacées: Soc. Bot. France Bull., v. 80, p. 79-90.

Deflandre, G., 1969. Nannofossiles siliceux I. Archaeomonadaceae: Fichier Micropaleontol. Gen. Ser. 19, Centre Natl. Rech. Sci., p. 1-9.

Edwards, A.R., 1973. Southwest Pacific regional unconformities encountered during Leg 21. In Burns, R.E., Andrews, J.E., et al., Initial Reports of the Deep Sea Drilling Project, Volume 21: Washington (U.S. Government Printing Office), p. 701-720.

Ehrenberg, C.G., 1837. Eine briefliche Nachricht des Hrn. Agassiz in Neuchatel über den ebenfalls aus mikroskopischen Kiesel-Organismen gebildeten Polirschiefer von Oran in Afrika: Ber. Verh. K. Preuss. Akad. Wiss. Berlin, p. $59-61$.

1839. Uber die Bildung der Kreidefelsen und des Kreidemergels durch unsichtbare Organismen: K. Abh. Akad. Wiss. Berlin., 1838 (1840, separate 1839), p. 59-148. 1841. Uber noch jetzt zahlreich lebende Thierarten der Kreidebildung und den Organismus der Polythalmien: Abh. Akad. Wiss. Berlin (1839), p. 81-174. 


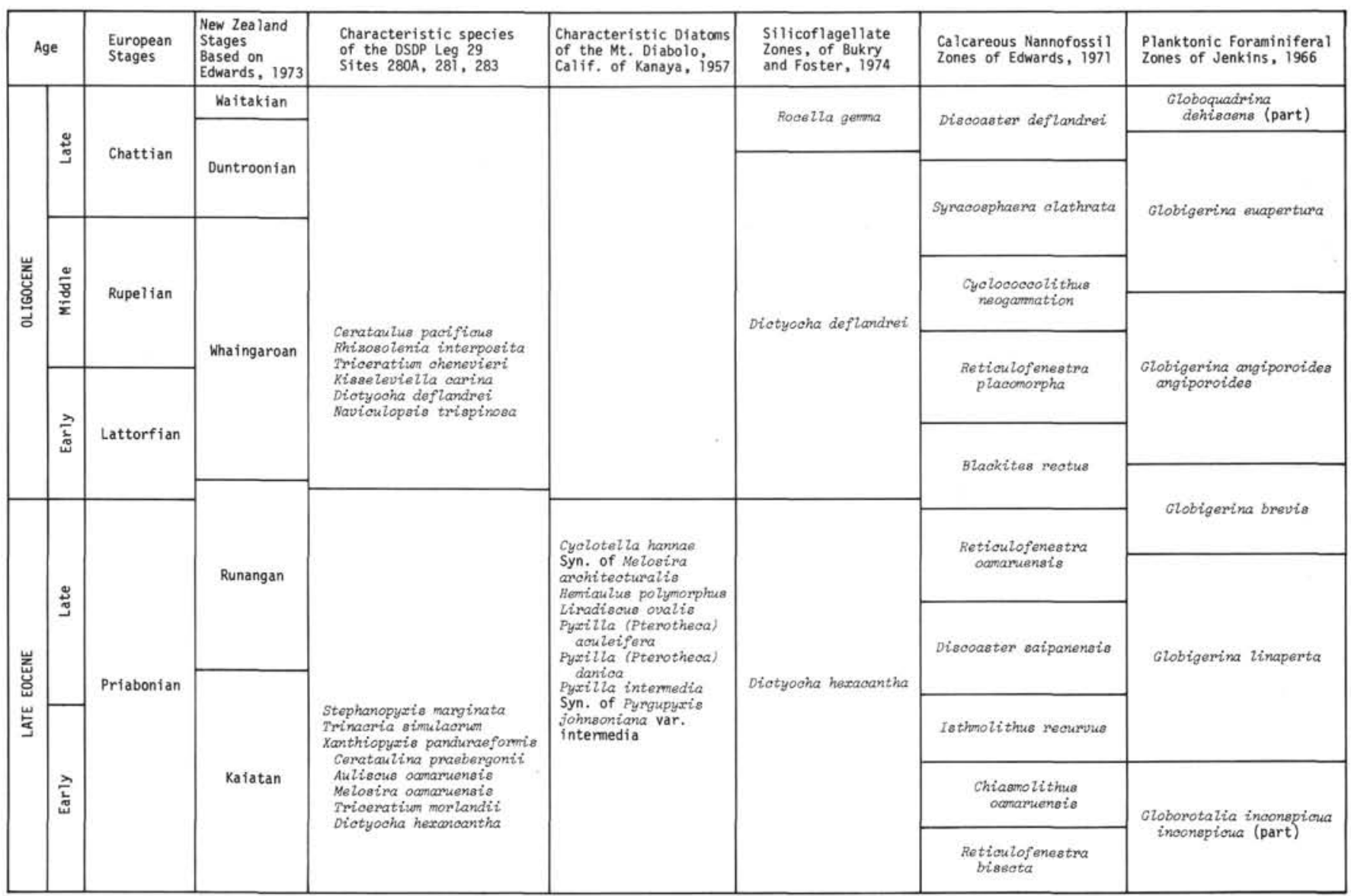

Figure 4. Correlation of different microfossil datum levels of the late Eocene to Oligocene interval. Correlation is based on the distribution of characteristic species or zones as listed by the different authors.

1843. Verbreitung und Einfluss des mikroskopischen Lebens in Süd-und Nord-Amerika: Abh. Akad. Wiss. Berlin, (1841), p. 291-446.

, 1844. Uber 2 neue Lager von Gebirgsmassen aus Infusorien als Meeres-Absatz in Nord-Amerika und elne Vergleichung Derselben mit den organischen KreideGebilden in Europa und Afrika: Ber. Akad. Wiss. Berlin, (1844), p. 57-97.

, 1854-1856. Mikrogeologie: v. 1, p. 1-374; v. 2, p. 188; Atlas: p. 1-31.

Forti, A., 1909. Studi per una Monografia del genere Pyxilla (Diatomee) e dei generi affini: La nouva Notarisia, v. 20, p. 19-38.

1912. Primo elenco delle Diatomee fossili contenute nei calcari marnosi biancastri di Monte Gibbio (Sassuolo = Emilia): La nouva Notarisia, v. 23, p. 79-84.

Frenguelli, J., 1940. Consideraciones sobre los silicoflagelados fósiles: Rev. Mos. La Plata, ser. 2, v. 2, p. 37-112.

Gleser, S.I., 1966. Silicoflagellatophyceae. In Flora plantarum cryptagamarum USSR: Acad. Sci. USSR, Institutum Botanicum, v. 7, p. 1-330.

1969. Pozdneehotsenovye kompleksy diatomovyh, kremnevyh zhgutikovyh vodoroslej $i$ ebriidej jugozapadnoj chasti turgajskogo progiba: Trudy VSEGEI, v. 130 , p. $67-84$.

Gleser, S.I. and Posnova, A.N., 1964. Diatomeae novae marinae ex Eoceno Kazachstaniae occidentalis: Novitates systematicae plantarum non vascularium, p. 59-66.

Gleser, S.I. and Sheshukova-Poretskaya, V.S., 1969. K istorii formirovanija pozdneehotsenovoj morskoj diatomovoj flory Ukrainy: Vestnik Leningradskogo Universiteta, v. 9, p. 60-73.

Greville, R.K., 1861-1866. Descriptions of new and rare diatoms: Trans. Micr. Soc., Ser., p. 1-20.

Grove, E. and Sturt, G., 1886-1887. On fossil marine diatomaceous deposit from Oamaru, Otago, New Zealand: J. Q. M. C., ser. 2, v. 2, 3.

Grunow, A., 1884. Diatomeen von Franz Josefs-Land: Akad. Wiss., v. 48 , p. 53-112.

Hanna, G.D., 1927. The lowest known Tertiary diatoms in California: J. Paleontol., v. 1, p. 103-127.

, 1931. Diatoms and silicoflagellates of the Kreyenhagen Shale: Mining in Calif., p. 197-201. , 1932. The diatoms of Sharktooth Hill, Kern County, California: Prof. Calif. Acad. Sci., ser. 4, v. 20, p. 161229.

Hendey, I.N., 1969. Pyrgupyxis, a New genus of diatoms from a South Atlantic Eocene core: Occas. Papers Calif. Acad. Sci., p. 1-6.

1972. Muelleriella limbata (Ehrenberg) Van Heurck in Eocene South Atlantic Cores: Nova Hedwig., v. 39, p. 79-94.

Hustedt, F., 1927-1930. Die Kieselalgen Deutschlands, Osterreichs und der Schweiz: In Rabenhorst, L. (Ed.), Kryptogamen-FLora: Bd. 7, v. 1, p. 1-920.

Jousé, A.P., 1955. Species novae diatomacearum aetatis Paleogenae: Bot. Materiali otdela sporovyh rastenij, v. 10, p. $81-103$.

Kanaya, T., 1957. Eocene diatom assemblages from the Kellogg and "Sidney" Shales, Mt. Diablo Area, California: 
Sci. Rept. Tohoku Univ. Sendai, Japan, ser. 2, v. 28, p. $27-$ 124.

, 1959. Miocene diatom assemblages from the Onnagawa Formation and their distribution in the correlative formations in Northeast Japan: Sci. Rept. Tohoku Univ. Sendai, Japan, ser. 2, v. 30, p. 1-130.

Koizumi, I., 1973. The Late Cenozoic diatoms of Sites 183193, Leg 19 Deep Sea Drilling Project. In Creager, J.S., Scholl, D.W., et al., Initial Reports of the Deep Sea Drilling Project, Volume 19: Washington (U.S. Government Printing Office), p. 805-855.

Lefébure, P. and Chenevière, E., 1938. Description et Iconographie de Diatomées rares ou nouvelles: Soc. France Micr. Bull., v. 7, p. 8-12.

Lemmermann, E., 1901. Silicoflagellatae: Deutsche Bot. Ges., v. 19 , p. $247-271$.

Mandra, Y.T., 1968. Silicoflagellates from the Cretaceous, Eocene, and Miocene of California, U.S.A.: Calif. Acad. Sci. Proc., v. 36. p. 231-277.

1969. A new genus of silicoflagellata from an Eocene South Atlantic Deep-Sea Core (Protozoa: Mastigophora): Calif. Acad. Sci. Occas. Papers, no. 77, p. 1-7.

, 1971. Upper Eocene silicoflagellates from New Zealand: Antarctic J. United States, v. 6, p. 177-178.

Mann, A., 1925. Marine diatoms of the Philippine Islands: U.S. Natl. Mus., Bull. 100, v. 6, p. 1-182.

Martini, E., 1971. Standard Tertiary and Quaternary calcareous nannoplankton zonation: In Farinacci, A. (Ed.), Roma (Tecnoscienza), p. 739-785, Plankt. Conf. Second, Rome 1970 Proc.

Pantocsek, J., 1886-1905. Beiträge zur Kenntnis der fossilen Bacillarien Ungarns: 1886 , v. 1, p. 1-74; 1889, v. 2, p. 1-23; 1892 , v. $3 ; 1905$, p. $1-118$.
Paramonova, N.V., 1964. Materialy po Diatomovym vodoroslyam iz Paleogenovyh otlozhenij Severa-Zapadnoj Sibiri: Trudy VNIGRI, Paleofitologicheskij Sbornik: v. 239 , p. $232-246$.

Proshkina-Lavrenko, A.I., 1949. Diatomovyj Analiz, Centrales, Mediales: Bot. Inst. Akad. Nauk. SSSR., v. 2, p. 1238.

Reinhold, T., 1937. Fossil diatoms of the Neogene of Java and their zonal distribution: Verhandl Geol. Mijnbouwk. Gen. von Nederland en Kol. Geol., ser. 12, p. 43-133.

Sheshukova-Poretskaya, V.S., 1962. Neogenovye morskie diatomovye vodorosli Sakhalina i Kamchatki: p. 1-432.

Sheshukova-Poretskaya, V.S. and Gleser, S.I., 1964. Diatomeae marinae novae e Paleogeno Ucrainiae: Nov. systematicae plantarum non vascularium, p. 78-92.

Schmidt, A., 1874-1959. Atlas der Diatomaceen-Kunde: v. 1120.

Schrader, H.-J., 1969. Die Pennaten Diatomeen aus dem Obereozän von Oamaru, Neuseeland: Nova Hedwig., v. 28, p. 1-124.

Schulz, P., 1928. Beiträge zur Kenntnis fossiler und recenter Silicoflagellaten: Bot. Arch., v. 21, p. 225-292.

Strelnikova, N.I., 1960. Diatomovye vodorosli i kremnevye zhgutikovye iz paleogenovyh otlozhenij Obsko-purskogo mezhdyrechya: Trudy VNIGRI, v. 158, p. 33-45.

Van Heurck, H., 1880-1885. Synopsis des diatomées de Belgique: Atlas, v. 1-2, p. 1-235.

Van Heurck, H., 1896. A treatise on the Diatomaceae: p. 1558. 


\section{PLATE 1}

Magnifications Figures 3-4, $\times 500$; Figures 1, 2, 5-13 $\times 1000$

Figures 1, 2 Melosira oamaruensis Gr. et St. Sample 281-14, CC.

Figures 3, $4 \quad$ Melosira clavigera Grun. Sample 281-15, CC.

Figures 5, 6 Melosira architecturalis Brun. Sample 281-14-1, 140-142 cm.

Figures 7,8 Pseudopodosira marginata n. sp. (Figure 7, Holotype).

Sample 281-16, CC

Figures 9, 10 Pseudopodosira corolla (A. Schm.) n. comb. Sample 281-14-1, 140-142 cm.

Figures 11-13 Stephanopyxis superba (Grev.) Grun. Sample 281-16, CC. 


\section{PLATE 1}
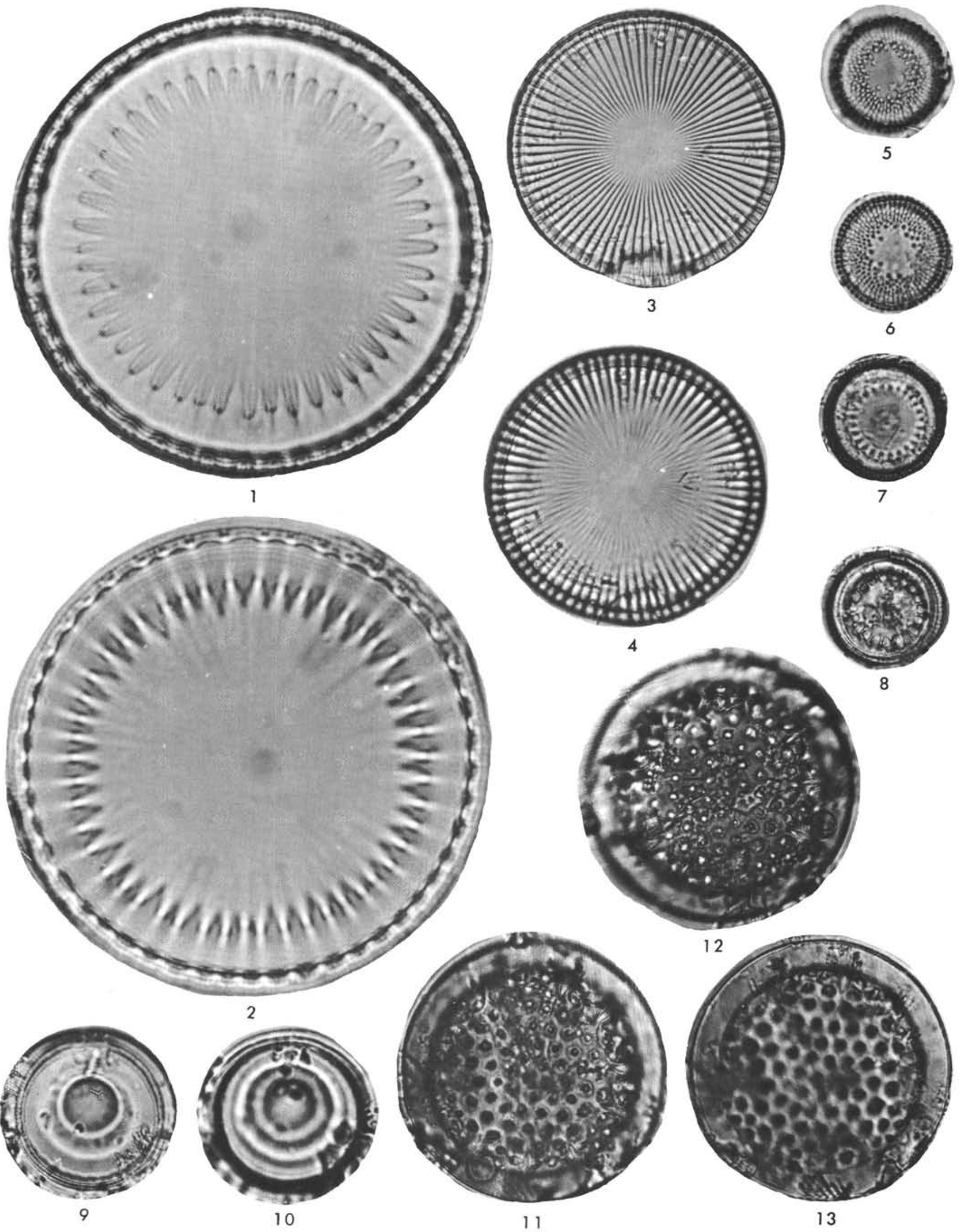


\section{PLATE 2}

Magnifications Figures 1-4, 7, $8 \times 1000$; Figures 5, $6 \times 500$

Figures 1,2 Melosira oamaruensis Gr. et St. Sample 283-4, CC.

Figures 3, $4 \quad$ Melosira clavigera Grun. Sample 283-6, CC.

Figures 5,6 Stephanopyxis marginata Grun. Sample 283-2, CC.

Figures 7,8 Podosira sp.

Sample 283-3, CC. 
PLATE 2
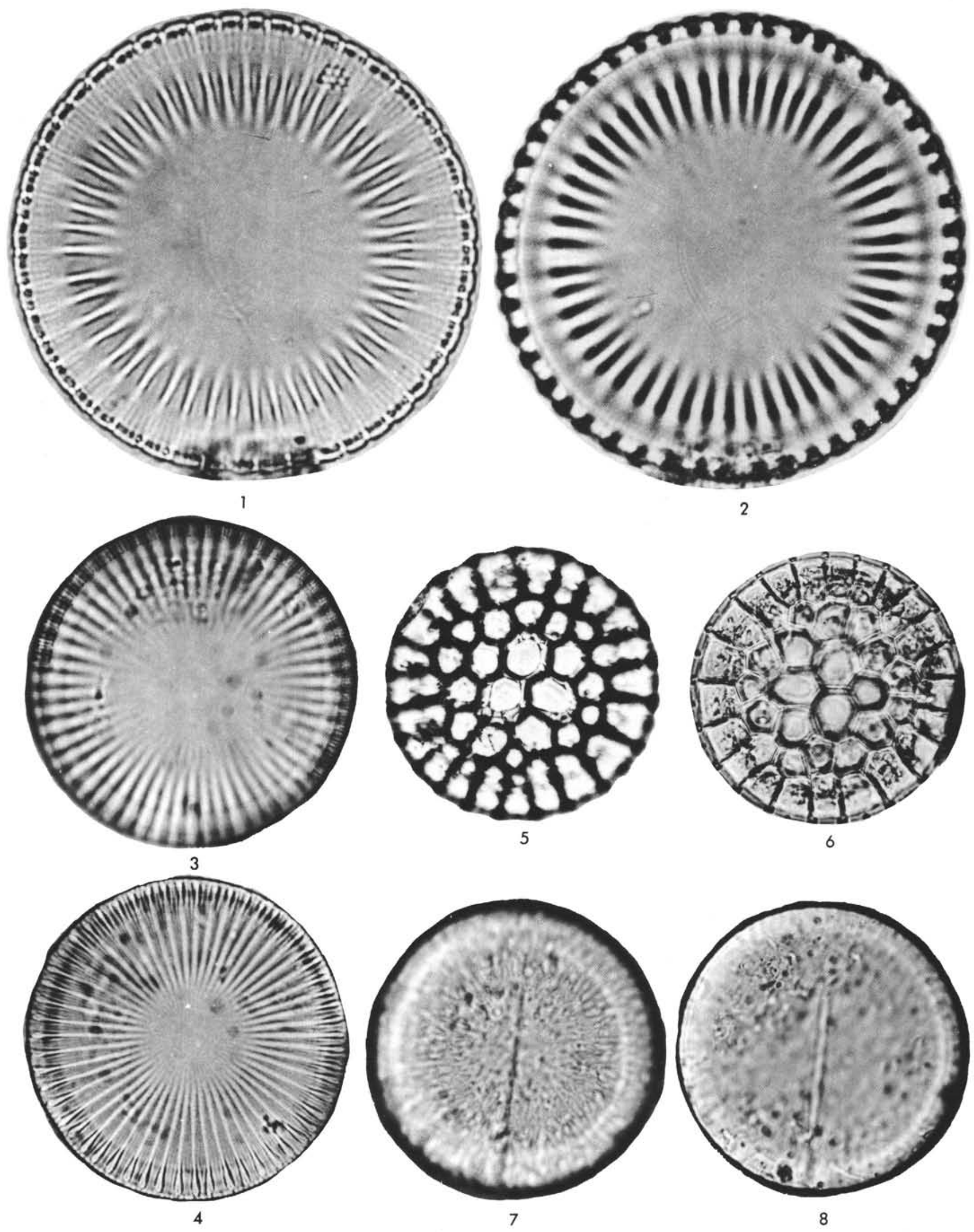


\section{PLATE 3}

Magnifications Figures 1-2, 7-9 $\times 1000$; Figures 3-6 $\times 500$

Figures 1,2 Stephanopyxis megapora Grun. Sample 281-16, CC.

Figures 3, 4 Stephanopyxis grunowii Gr. et St. Sample 281-15, CC.

Figures 5,6 Stephanopyxis marginata Grun. Sample 281-16, CC.

Figure 7 Stephanopyxis cf. ferox (Grev.) Ralfs. Sample 281-16, CC.

Figures 8,9 Stephanopyxis turris (Grev. et Arn.) Ralfs var. arctica Grun. f. ?.

Sample 281-15, CC. 
PLATE 3
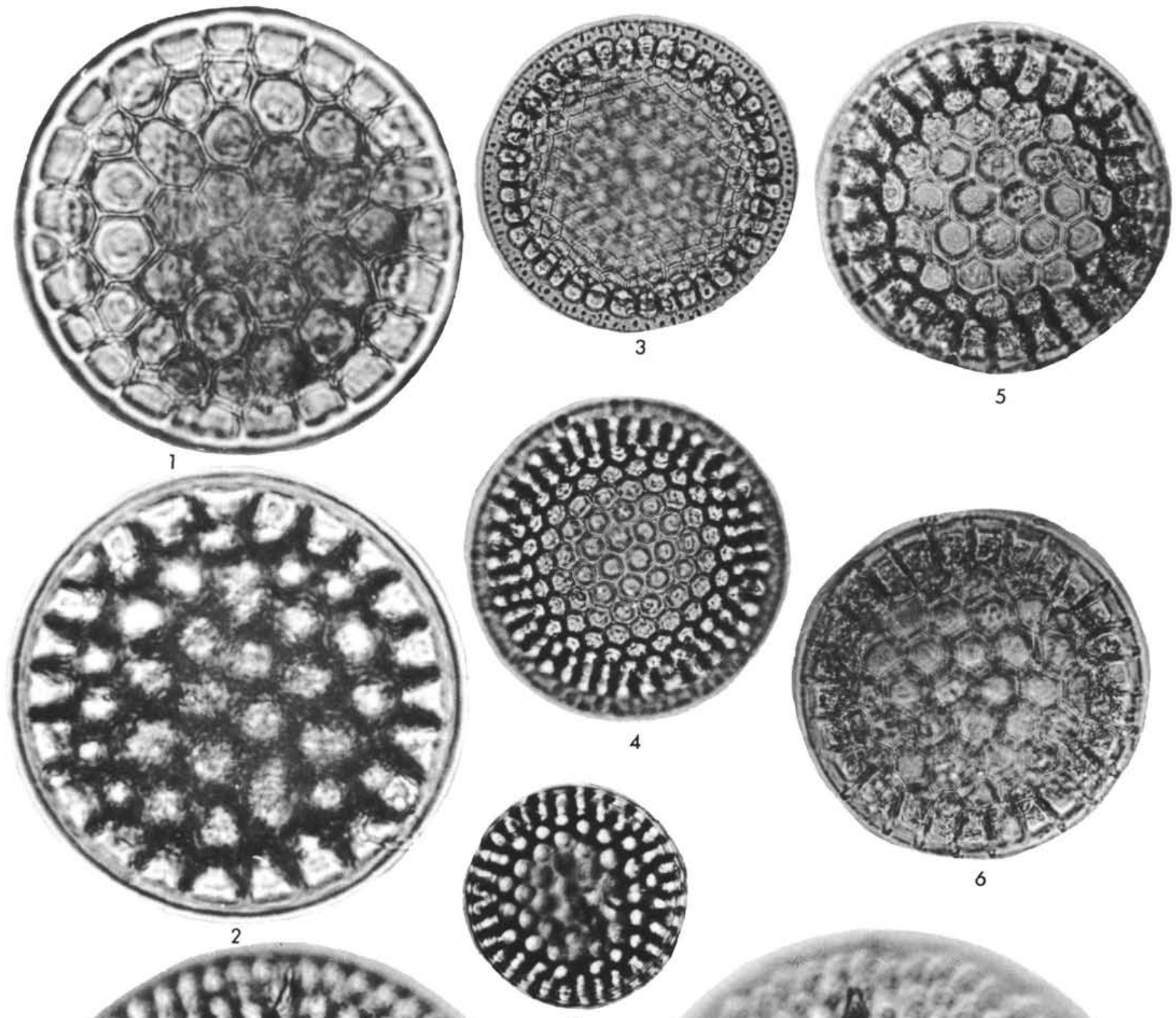

6
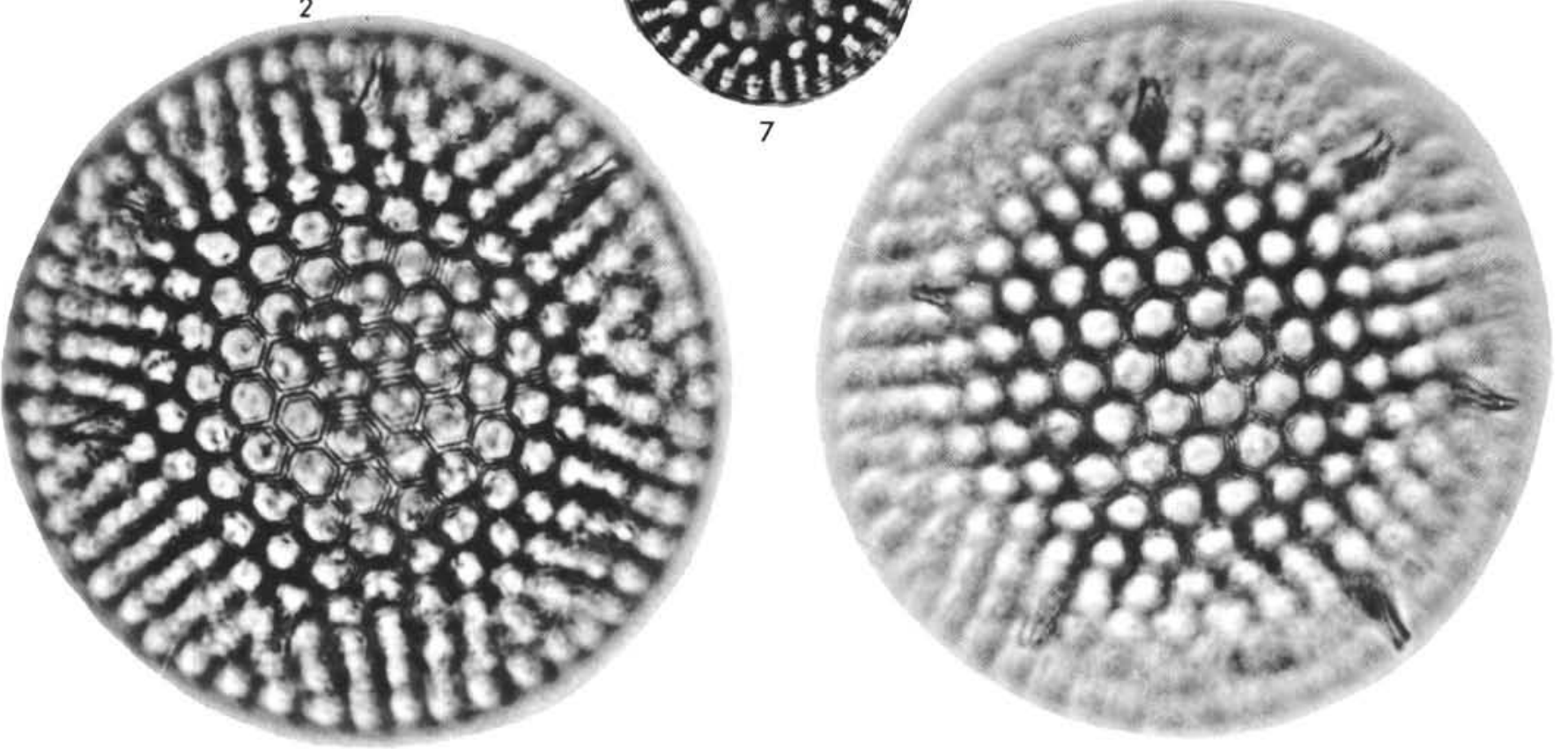
PLATE 4

Magnifications $\times 500$

Figures 1, 2 Stephanopyxis grunowii Gr. et St. Sample 283-6, CC.

Figures 3,4 Stephanopyxis eocaenicus n. sp. Holotype. Sample 283-6, CC.

Figures 5-7 Endictya robusta (Grev.) Hanna et Grant. Sample 283-6, CC.

Figures 8, 9 Coscinodiscus radiatus Ehr. var. nodulifer Reinhard.

Sample 283-6, CC.

Figures 10,11 Coscinodiscus oculusiridis Ehr. var. borealis (Bail.) Cl.

Sample 283-2, CC.

Figures 12-14 Coscinodiscus cf. radiatus Ehr.

Sample 283-6, CC. 
PLATE 4
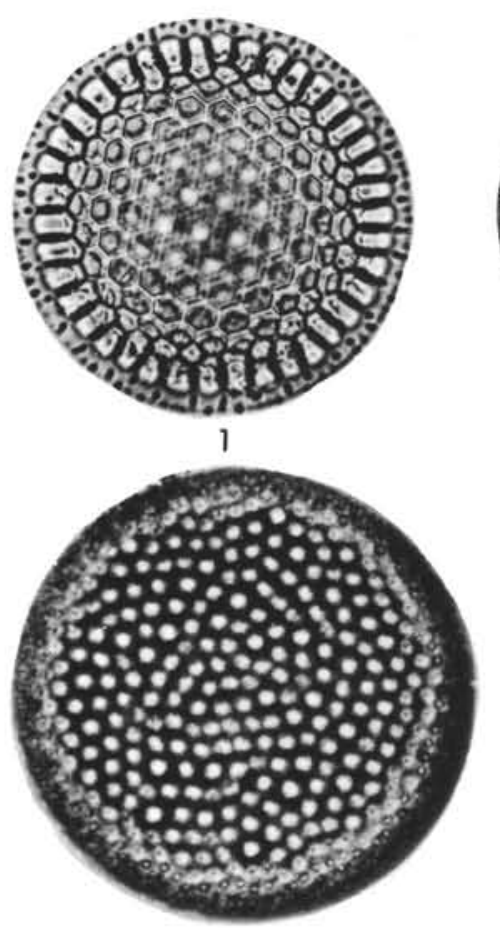

5

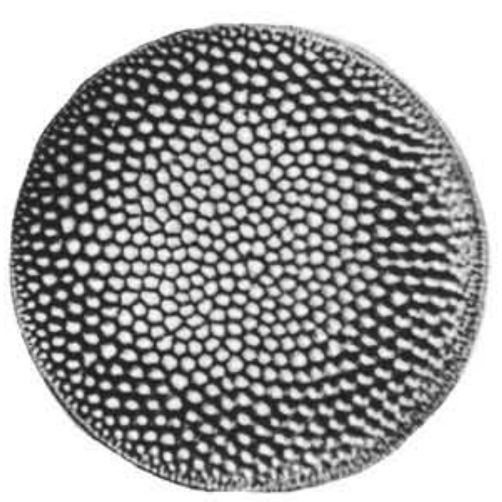

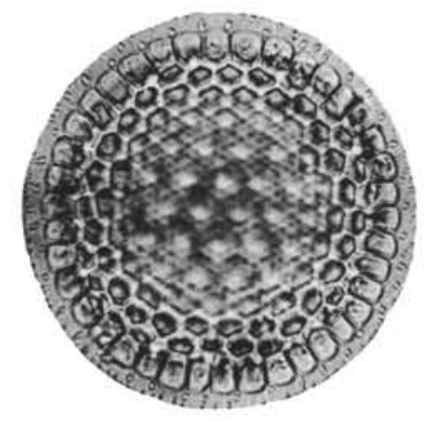

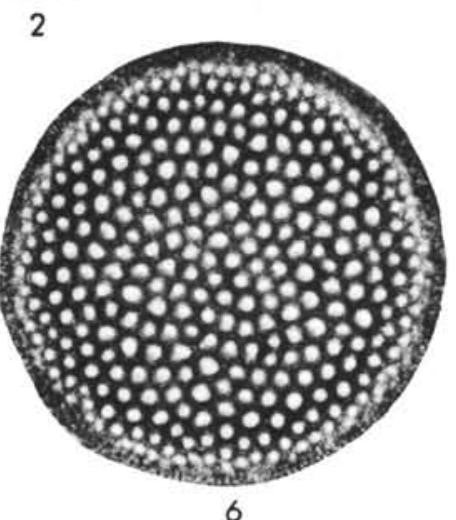

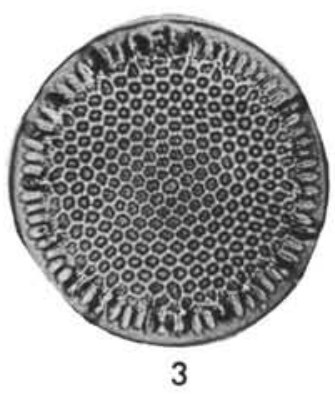
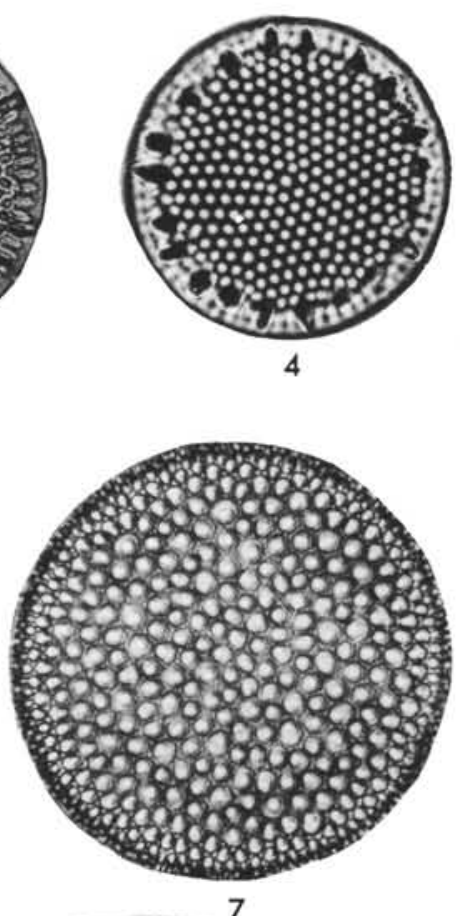

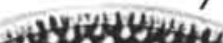

8

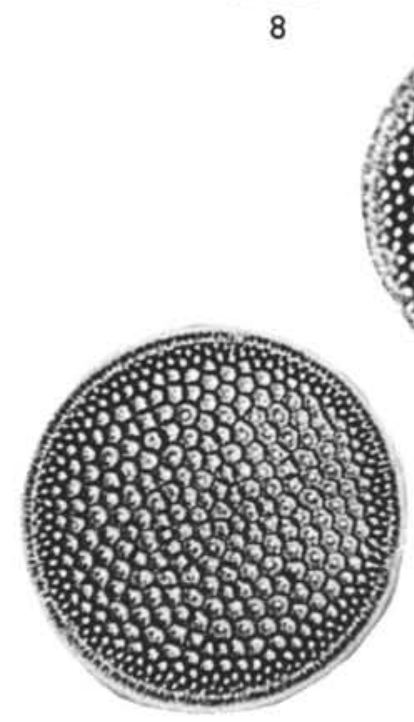

13

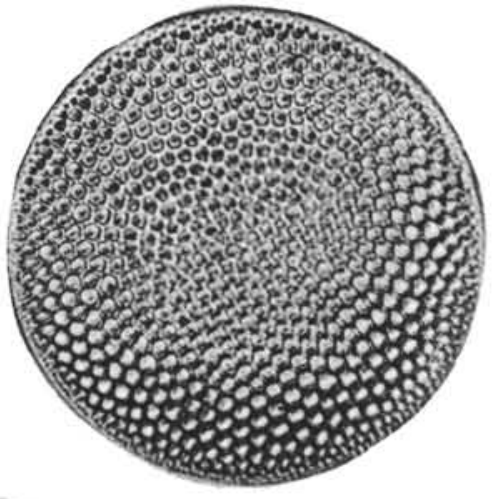

9

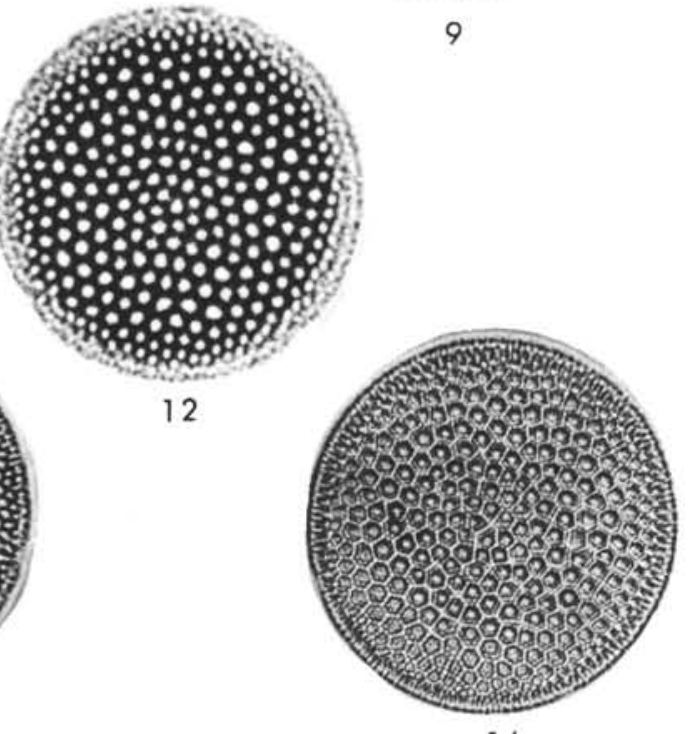

14
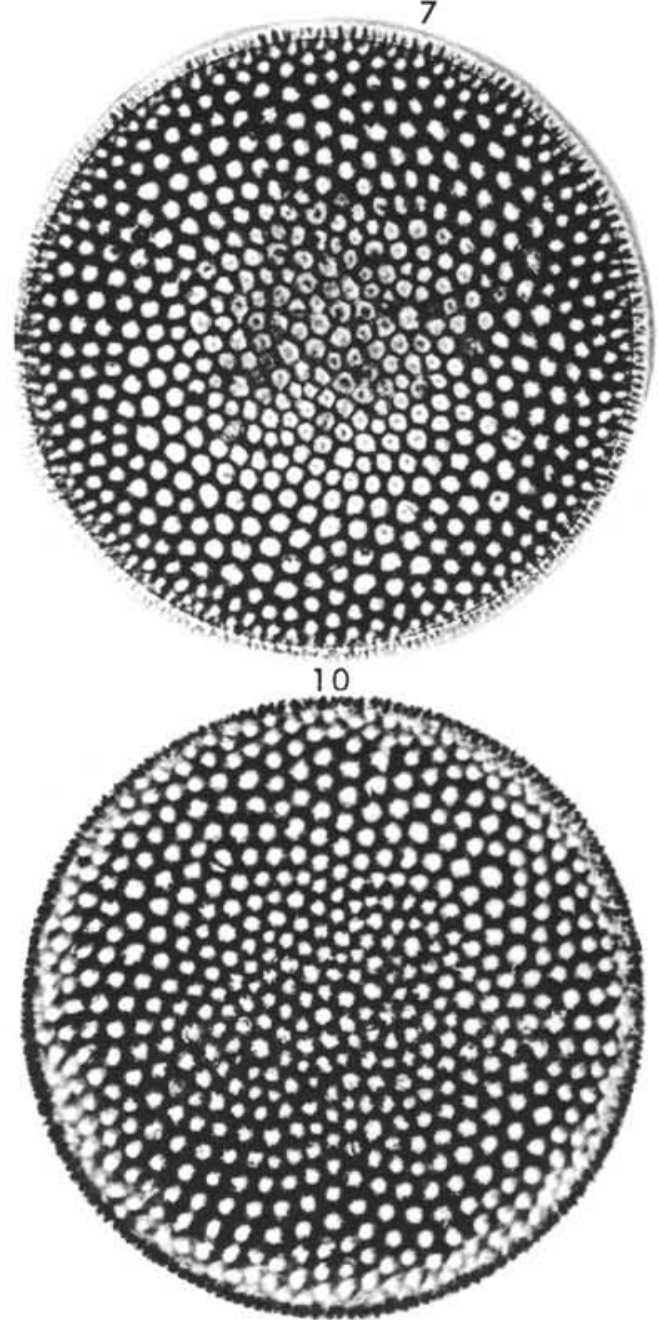

11 


\section{PLATE 5}

Magnifications Figures 1, $2 \times 1000$; Figures 3-8 $\times 500$

Figures 1,2 Stephanopyxis cf. antiqua Pant. Sample 281-14, CC.

Figures 3-5 Coscinodiscus cf. radiatus Ehr. Sample 281-15, CC.

Figures 6-8 Stephanopyxis cf. antiqua Pant. Sample 281-15, CC. 
PLATE 5

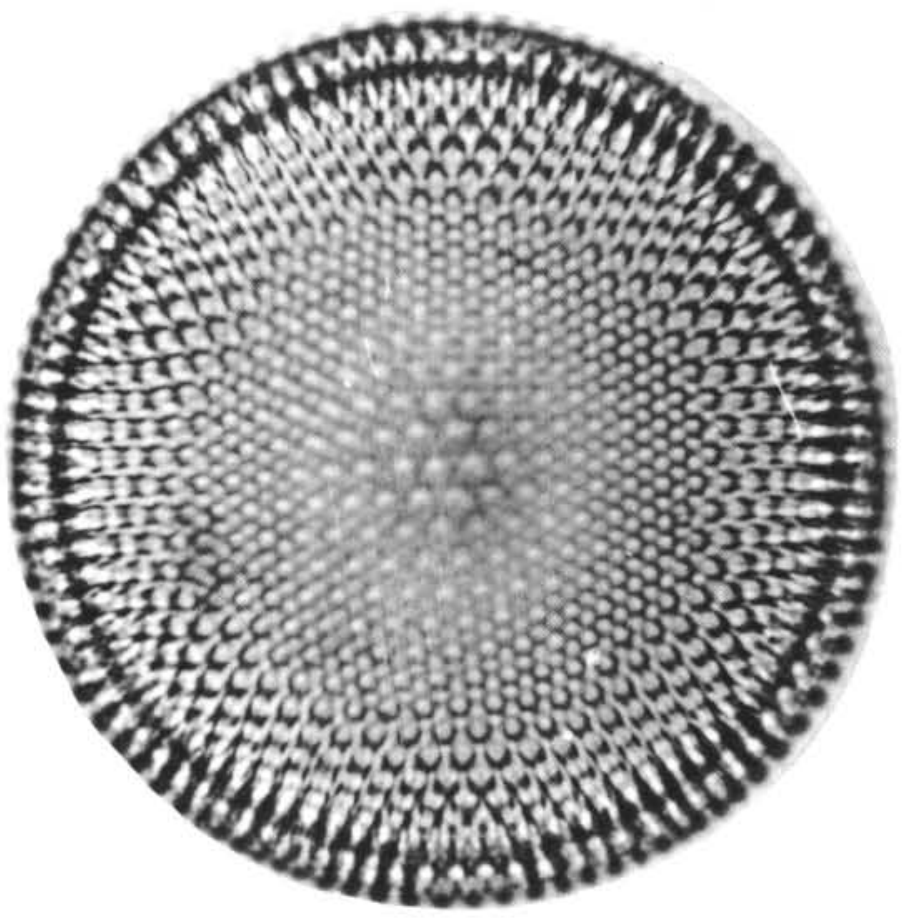

1

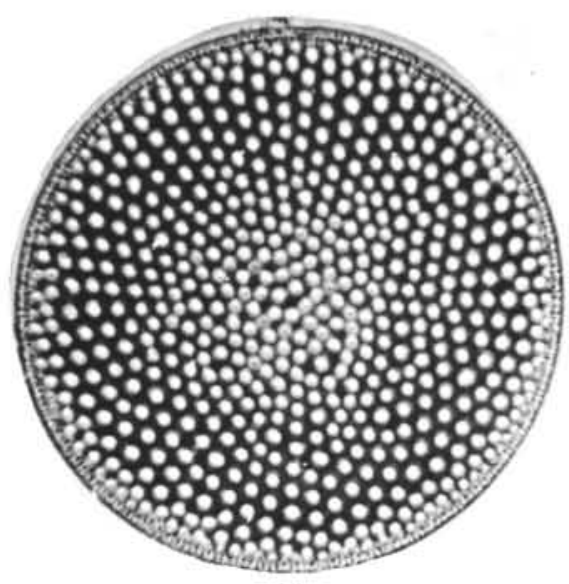

3

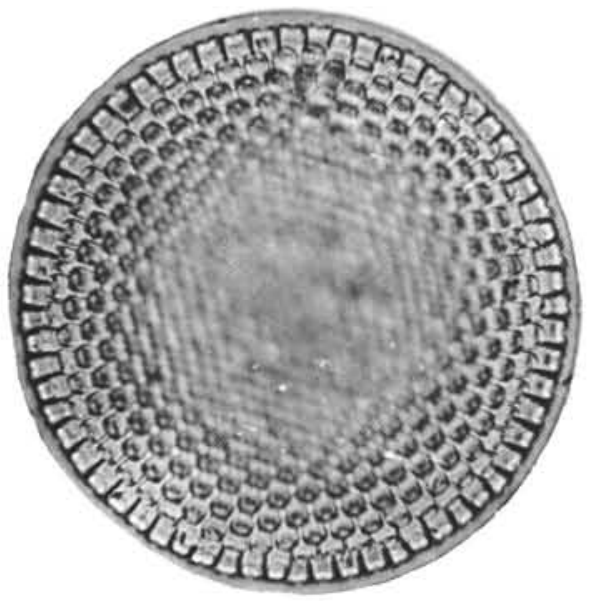

6

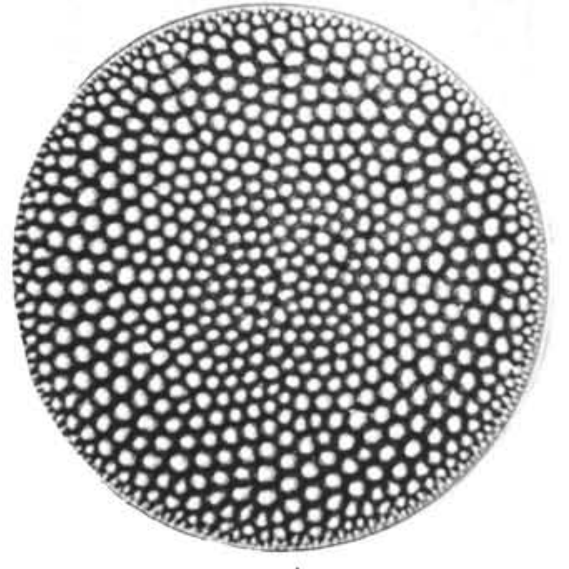

4

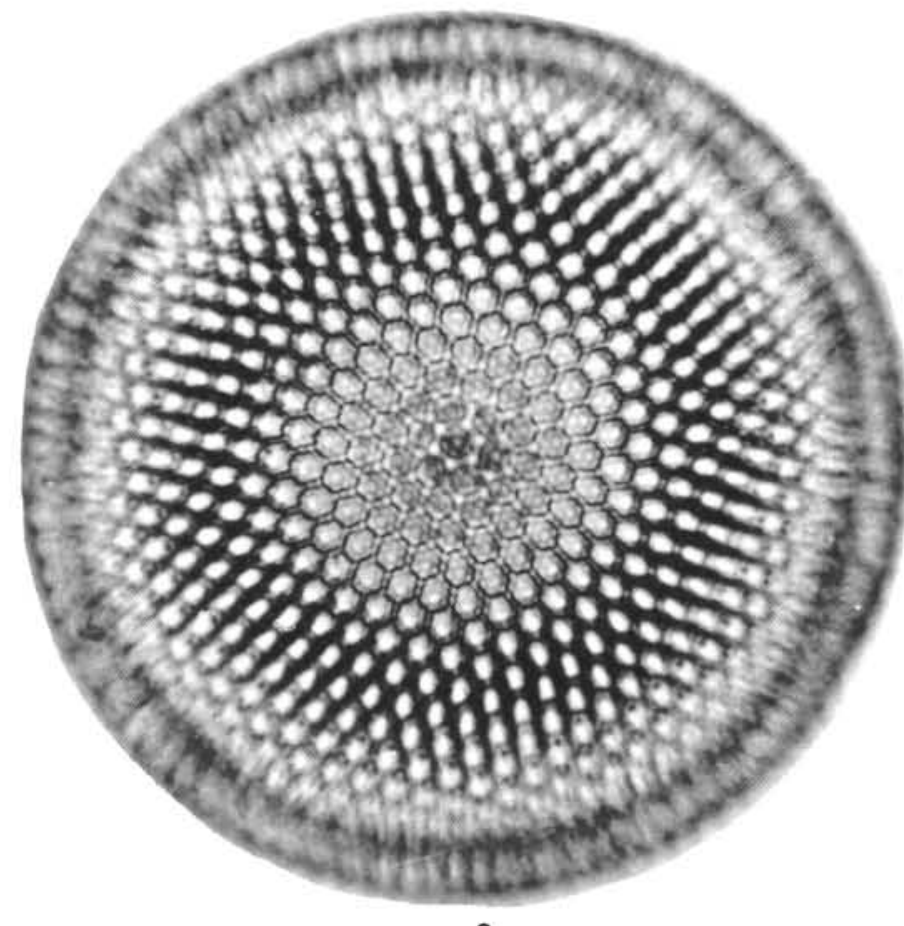

2
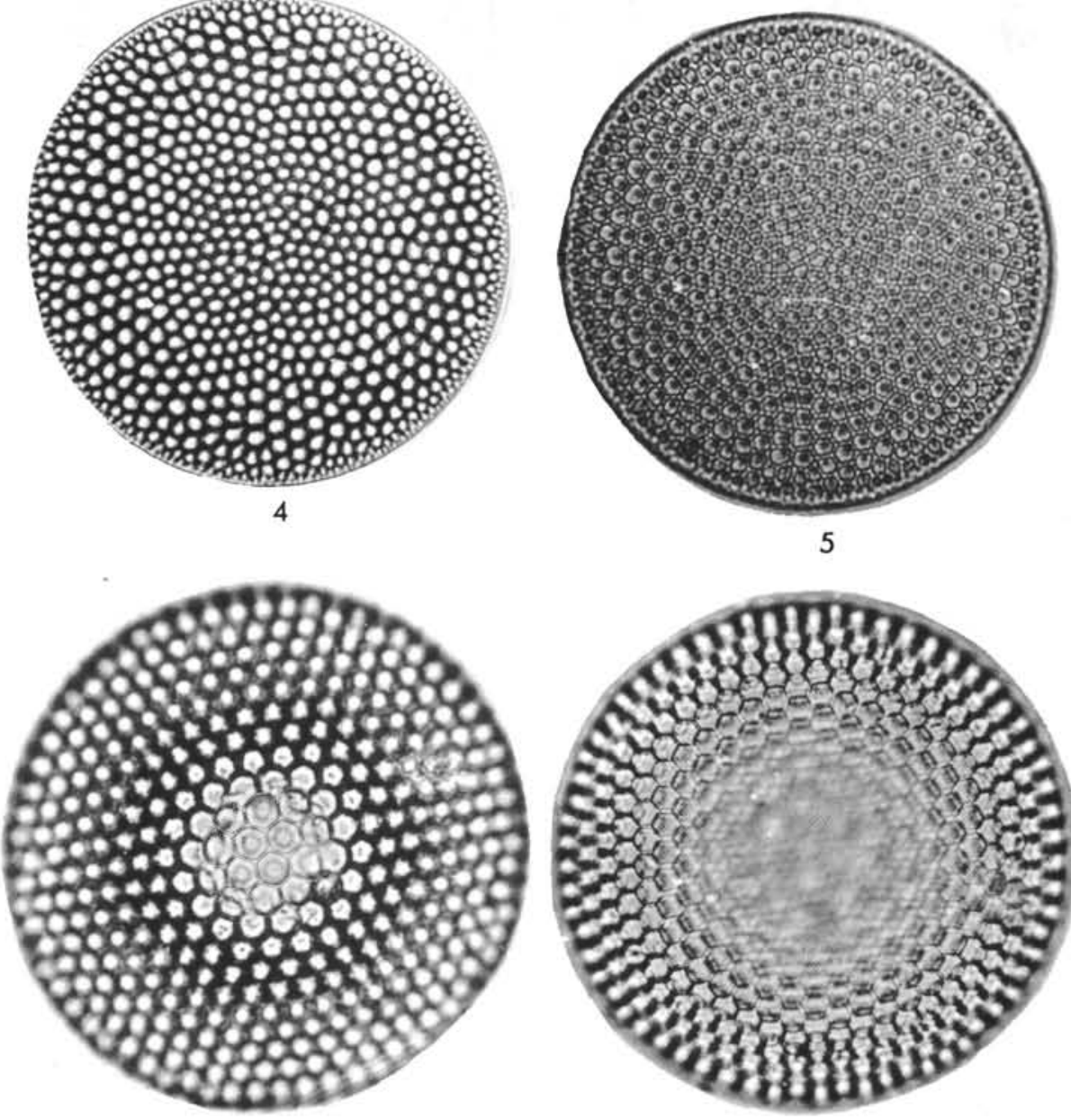

7

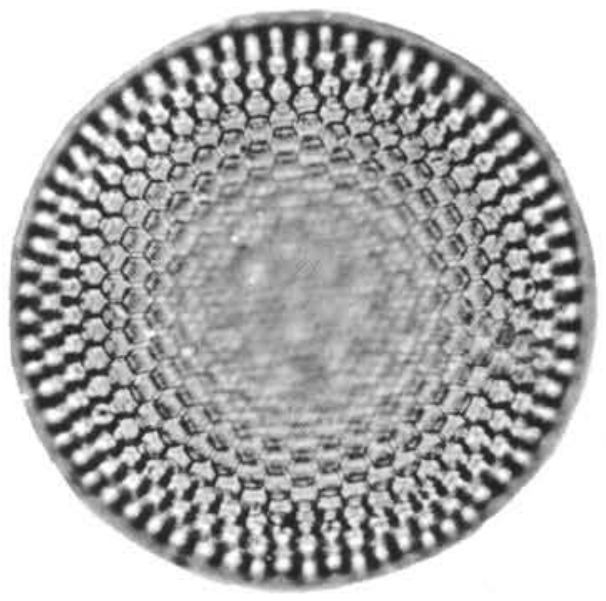


PLATE 6

Magnifications $\times 1000$

Figures 1,2 Coscinodiscus symbolophorus Grun. var. oamaruensis A. Schm.

Sample 283-4, CC.

Figures 3,4 Coscinodiscus radiatus Ehr. var. nodulifer Reinhard.

Sample 283-4, CC.

Figures 5,6 Coscinodiscus bulliens A. Schm.

Sample 283-3, CC. 


\section{PLATE 6}
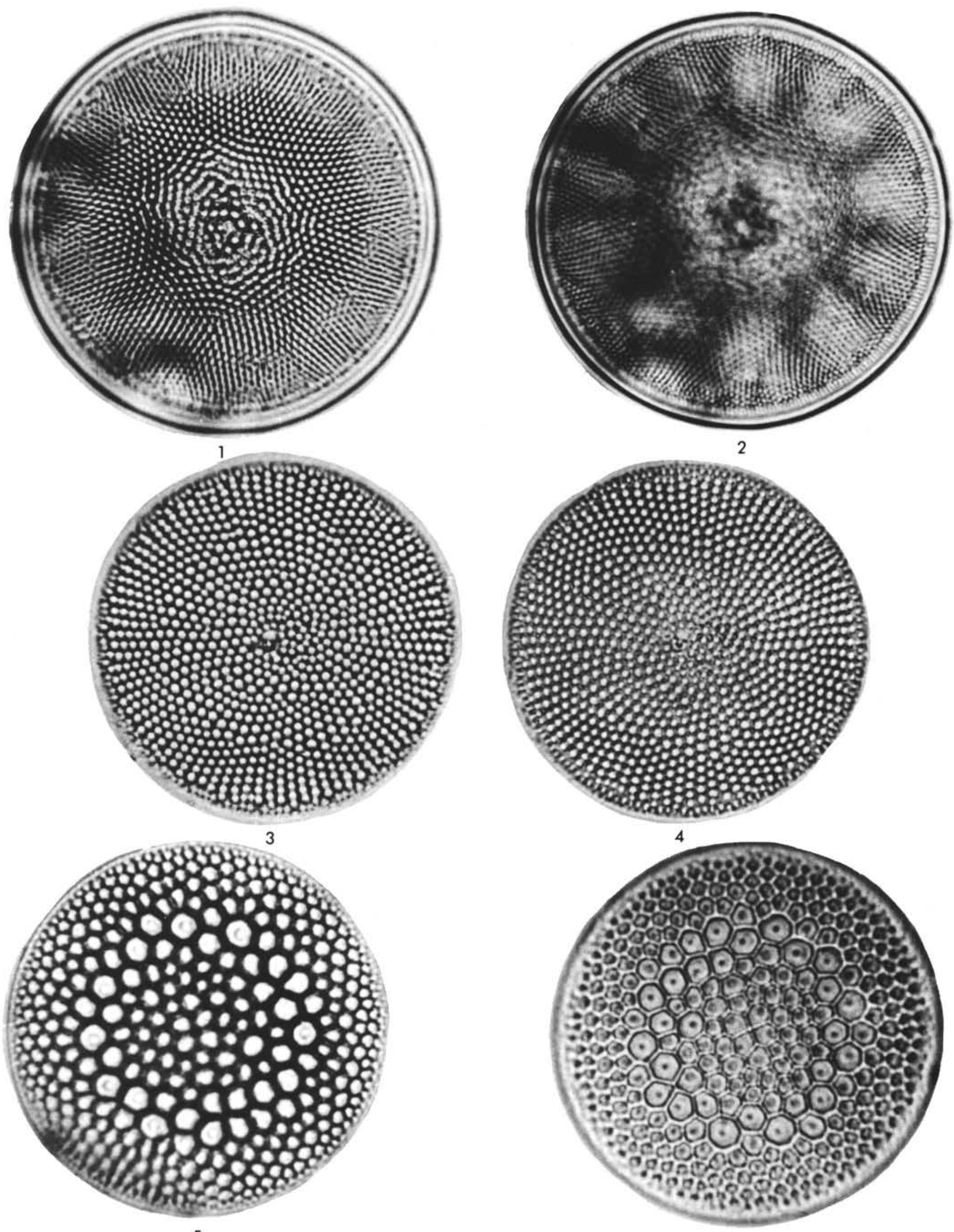
M. HAJÓS

PLATE 7

Magnifications $\times 1000$

Figures 1-3 Coscinodiscus spiralis n. sp.

Sample 283-4, CC.

1, 2. Holotype.

Figures 4, 5 Coscinodiscus denarius A. Schm.

Sample 283-4, CC. 


\section{PLATE 7}

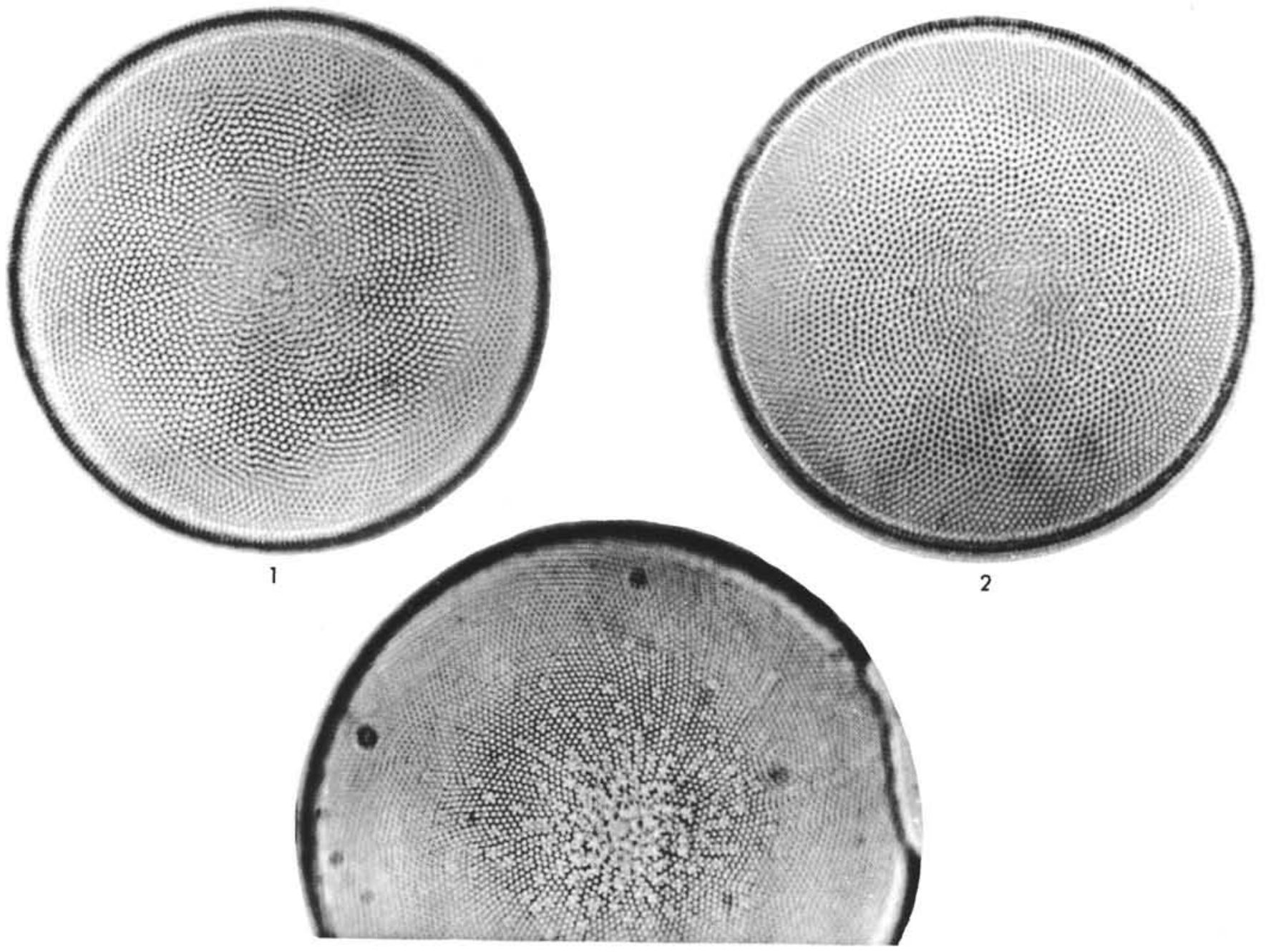

3
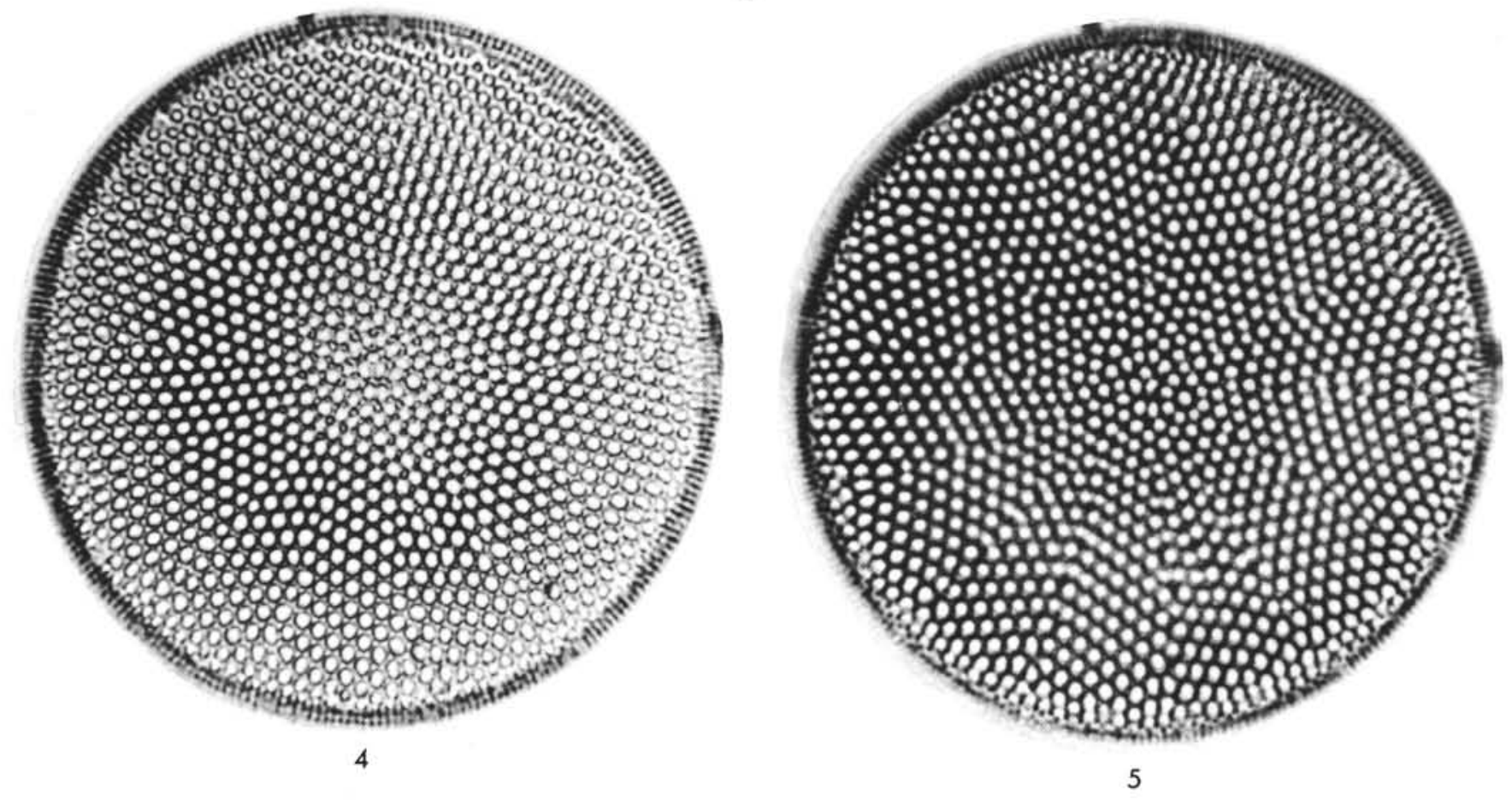


\section{PLATE 8}

Magnifications Figures 1, 2, 6, $7 \times 1000$; Figures 3-5 $\times 500$

Figures 1,2 Arachnoidiscus schmidti n. sp. Holotype. Sample 283-4, CC.

Figures 3-5 Auliscus gleseri n. sp. Holotype. Sample 283-6, CC.

Figures 6,7 Corona magnifica Lef. et Chen. Sample 283-3, CC. 

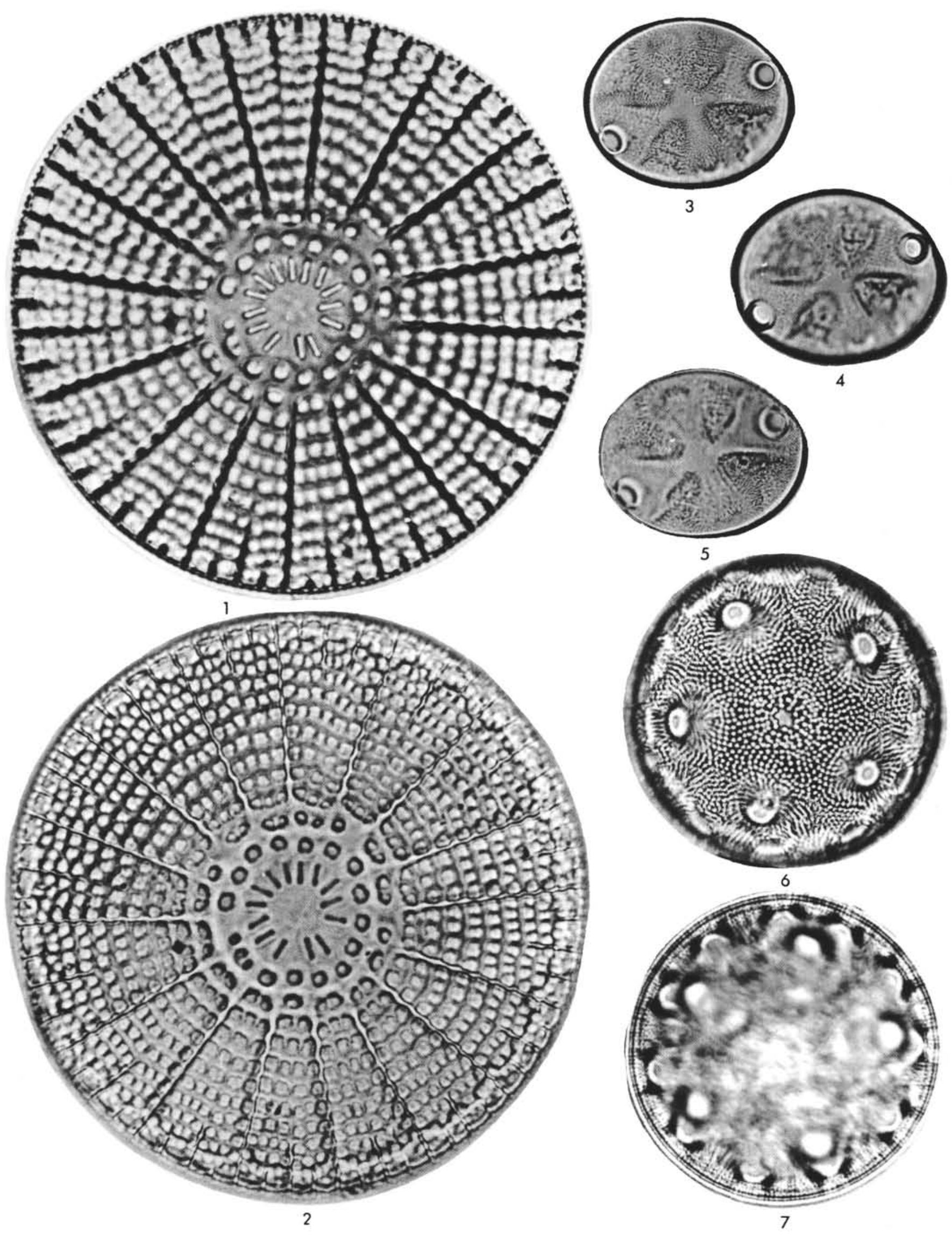


\section{PLATE 9}

Magnifications Figures 1-3 $\times 1000$; Figures 4-6 $\times 500$

Figures 1,2 Arachnoidiscus indicus Ehr.

Sample 283-4, CC.

Figure 3 Aulacodiscus rattrayii Gr. et St.

Sample 283-3, CC.

Figure 4 Actinocyclus octonarius Ehr. var.?

Sample 283-3, CC.

Figure $5 \quad$ Chaetoceros $\mathrm{sp}$.

Sample 283-6, CC.

Figure 6 Actinoptychus splendens (Shadb.) Ralfs.

Sample 283-3, CC. 


\section{PLATE 9}
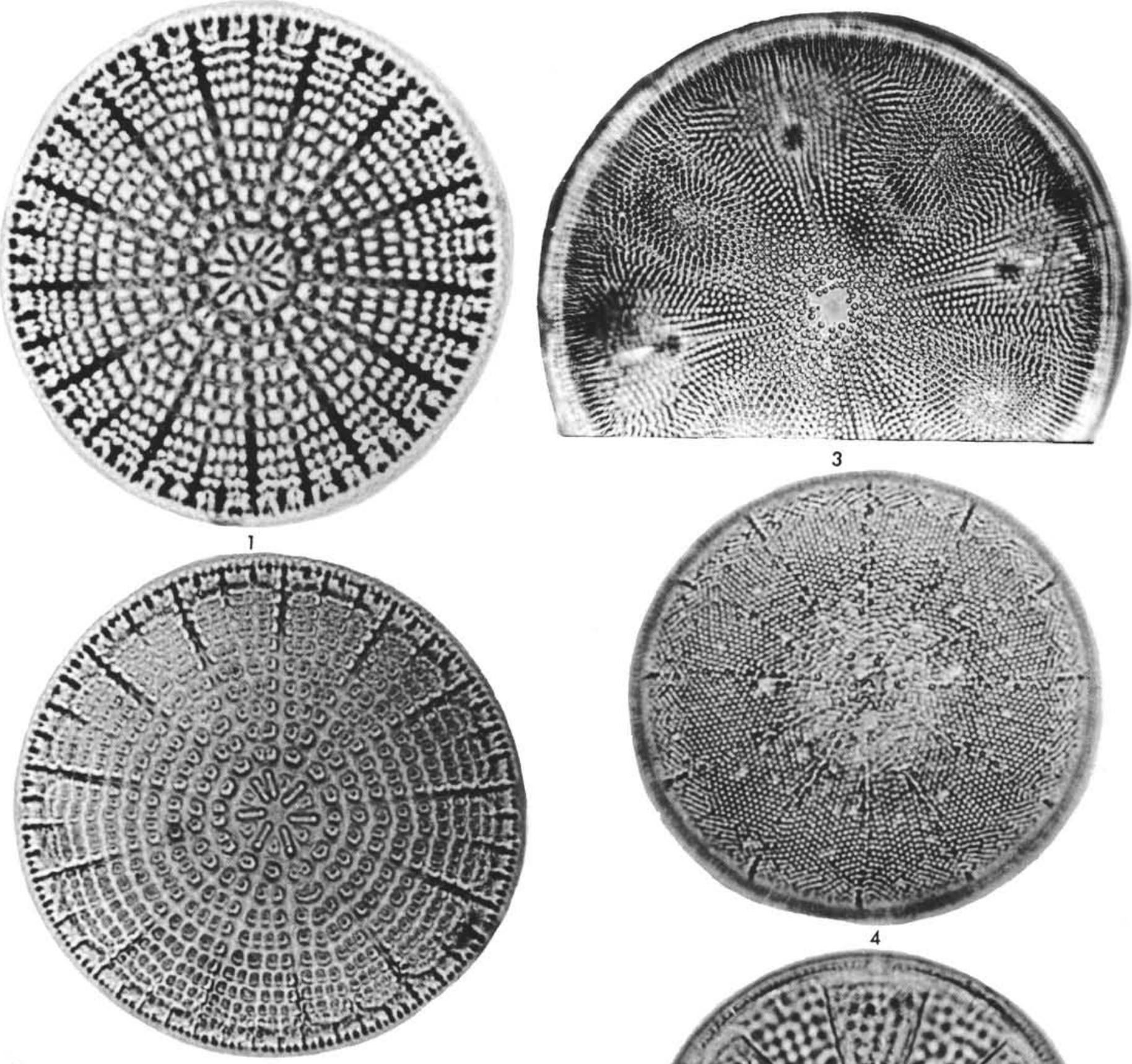


\section{PLATE 10}

Magnifications Figures 1-3, $7 \times 1000$; Figures 4-6, $\times 500$

Figure 1 Coscinodiscus symbolophorus Grun. var. oamaruensis A. Schm.

Sample 281-14, CC.

Figures 2, 3 Arachnoidiscus russicus Pant.

Sample 281-16, CC.

Figures 4-6 Stictodiscus grovei A. Schm.

Sample 281-15, CC.

Figure $7 \quad$ Auliscus oamaruensis Gr. et St.

Sample 281-15, CC. 

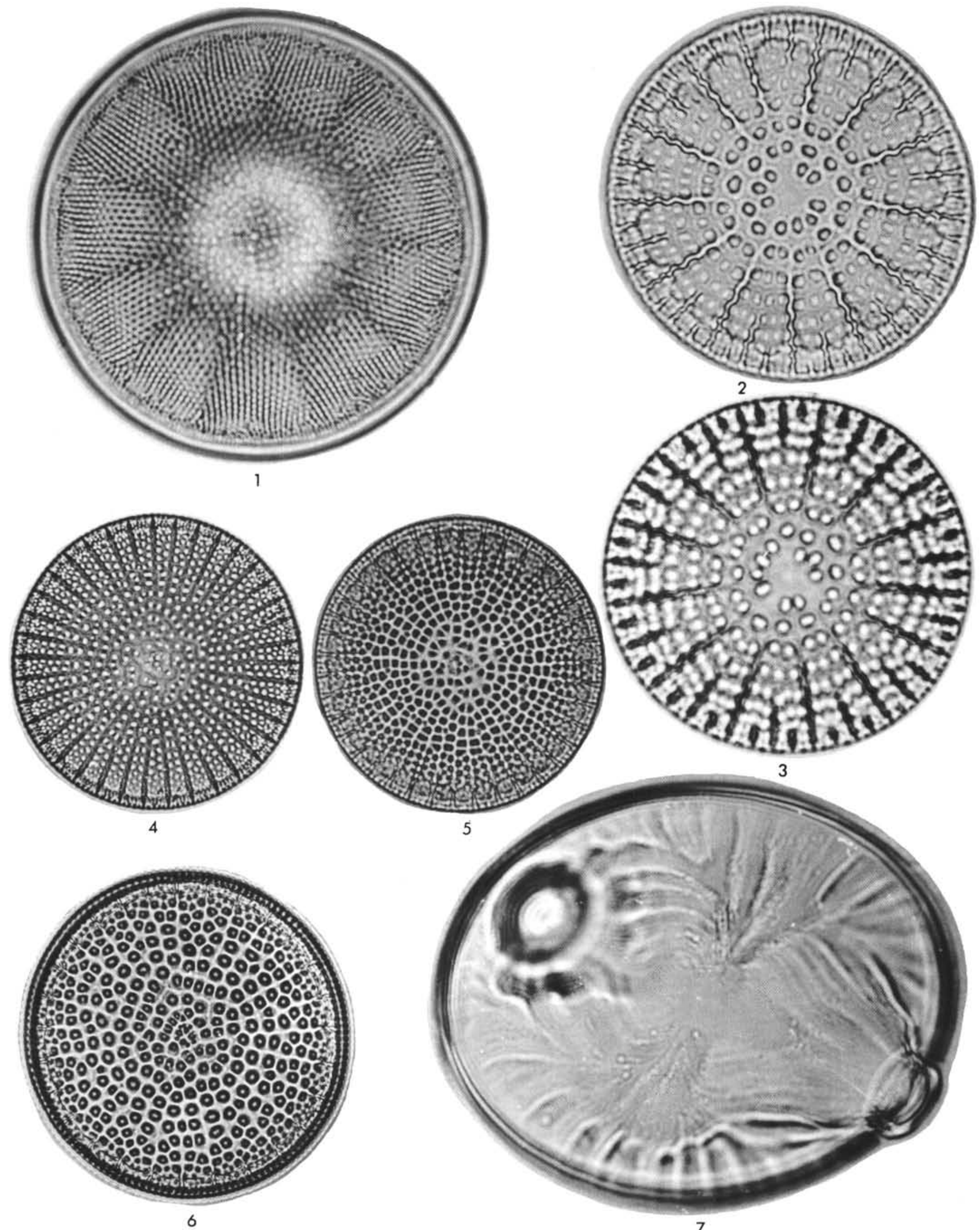
PLATE 11

Magnifications $\times 1000$

Figures 1-3 Muelleriopsis limbata (Ehr.) Hendey. Sample 281-15, CC.

Figure 4 Muelleriopsis limbata (Ehr.) Hendey. Sample 281-14, CC.

Figure $5 \quad$ Xanthiopyxis panduraeformis Pant. Sample 281-16, CC.

Figure $6 \quad$ Xanthiopyxis cf. acrolopha Forti. Sample 281-16, CC. 


\section{PLATE 11}
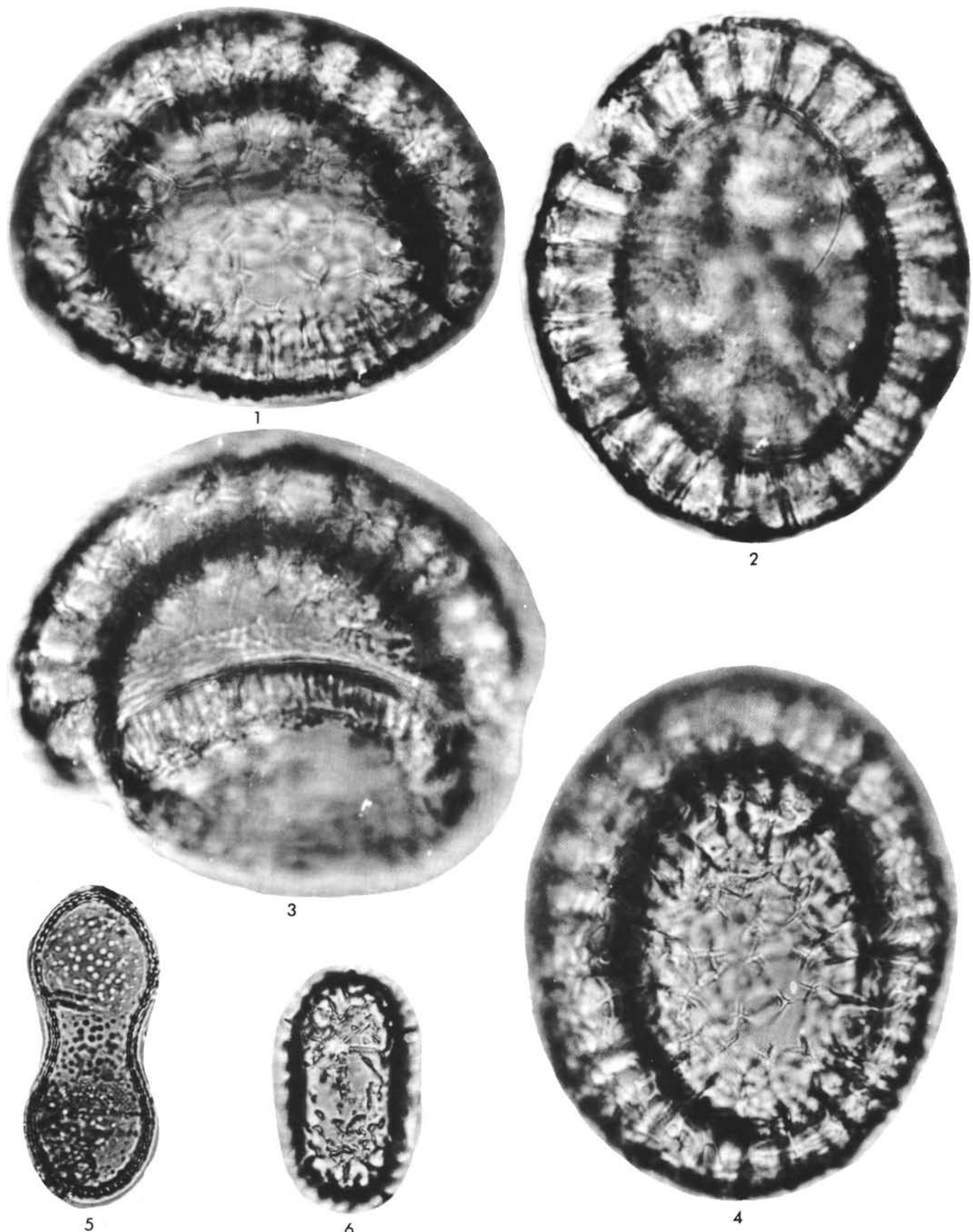


\section{PLATE 12}

Magnifications $\times 500$

Figure $1 \quad$ Rhizosolenia sp.

Sample 281-15, CC.

Figures 2, 3 Triceratium oamaruense Gr. et St.

Sample 281-14, CC.

Figures 4,5 Triceratium castellatum West var.? Sample 281-15, CC.

Figures 6,7 Triceratium oamaruense Gr. et St. var. sparsim punctata $\mathrm{Gr}$.

Sample 281-14, CC.

Figures 8, 9 Triceratium pulvinar A. Schm.

Sample 281-14, CC. 


$$
\begin{aligned}
& \Delta \Delta \\
& \Delta \Delta \square \\
& \Delta \triangle \square
\end{aligned}
$$




\section{PLATE 13}

Magnifications Figures 1, $2 \times 1000$; Figures 3-8 $\times 500$

Figures 1,2 Triceratium crenulatum Gr. et St. Sample 283-4, CC.

Figures 3,4 Triceratium pulvinar A. Schm. Sample 283-6, CC.

Figures 5,6 Biddulphia rigida A. Schm. Sample 283-3, CC.

Figures 7,8 Triceratium morlandii Gr. et St. Sample 283-6, CC. 



\section{PLATE 14}

Magnifications Figures 1-3, 7-13 $\times 500$; Figures 4-6 $\times 1000$

Figures 1-3 Triceratium pulvinar A. Schm.

Sample 281-15, CC.

Figures 4-6 Triceratium pulvinar A. Schm. Detail of the structure of the valve mantle. Sample 281-15, CC.

Figures 7, 8 Triceratium pulvinar A. Schm.

Sample 281-14, CC.

Figure 9 Trinacria excavata Heib.

Sample 281-15, CC.

Figures 10-12 Pseudorutilaria monile Gr. et St.

Sample 281-16, CC.

Figure 13 Cerataulina praebergoni n. sp.

Sample 281-15, CC. 
PLATE 14
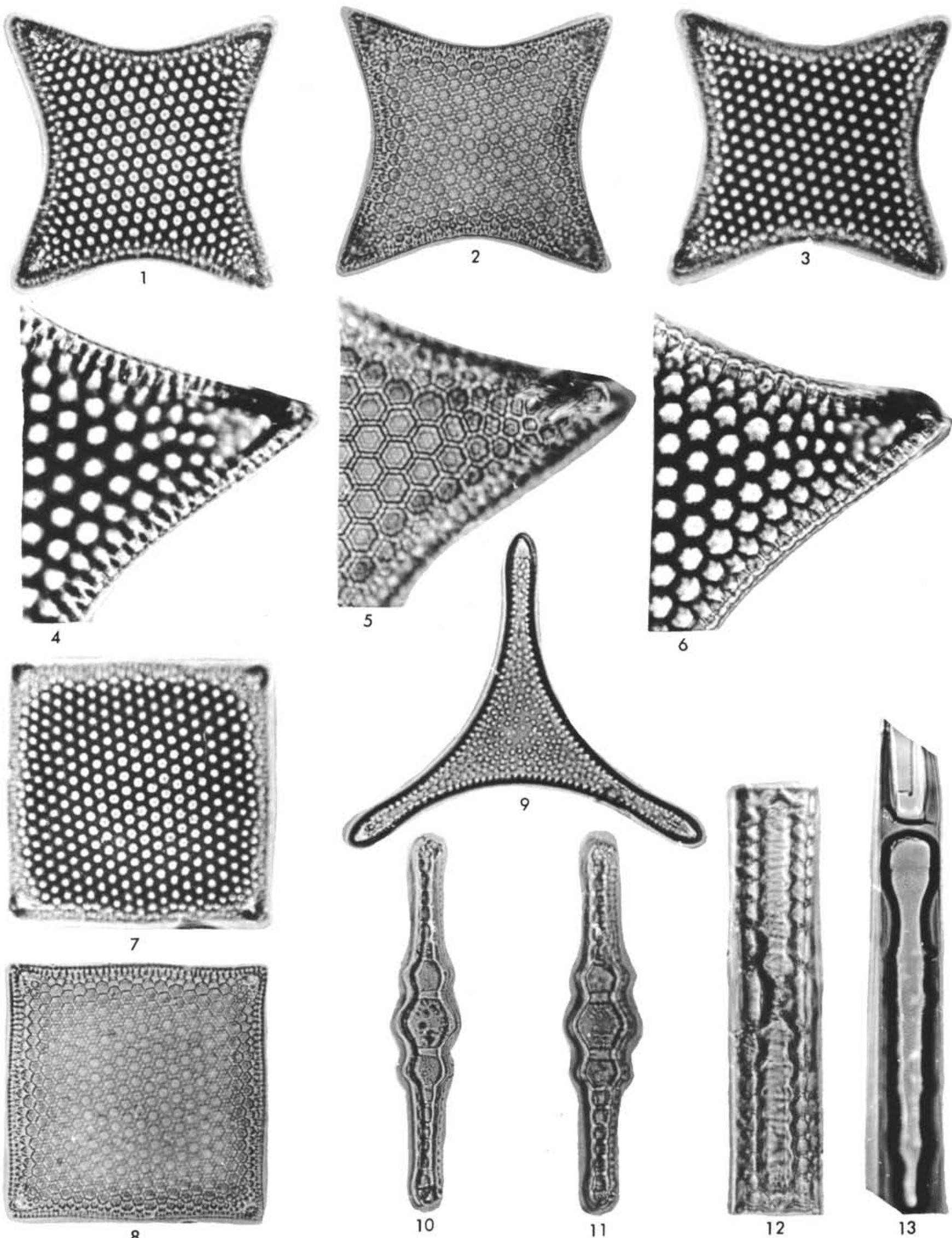

8

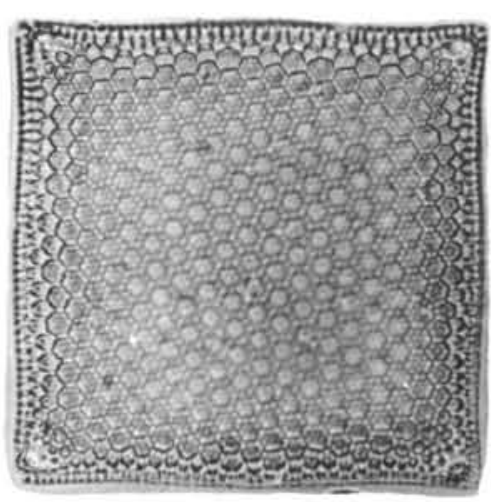

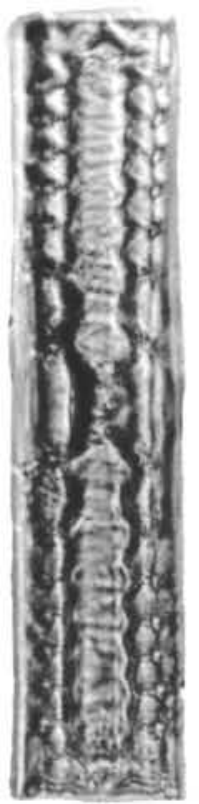

12

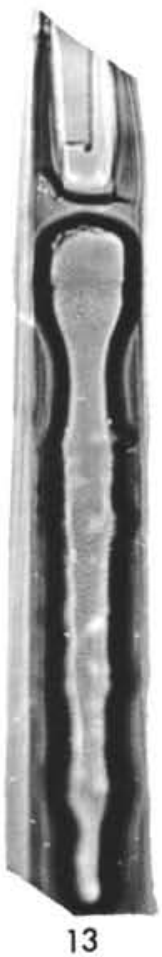


M. HAJÓS

\section{PLATE 15}

Magnifications Figures 1-9 $\times 500$; Figures 10, $11 \times 1000$

Figures 1,2 Trinacria simulacrum $\mathrm{Gr}$. et St.

Sample 283-6, CC.

Figures 3,4 Trinacria simulacrum $\mathrm{Gr}$. et St.

Sample 283-6, CC.

Figures 5-7 Cerataulina praebergoni n. sp.

Sample 283-6, CC.

Figures 8,9 Trinacria excavata Heib.

Sample 283-6, CC.

Figure 10 Hemiaulus caracteristicus n. sp. Holotype.

Sample 283-4, CC.

Figure 11 Hemiaulus polymorphus Grun. var.?

Sample 283-5, CC.

Figure 12 Hemiaulus polymorphus Grun. var.?

Stereoscan micrograph $\times 2200$. Sample 283-5, CC. 
DIATOMACEAE, ARCHAEOMONADACEAE, AND SILICOFLAGELLATAE

PLATE 15
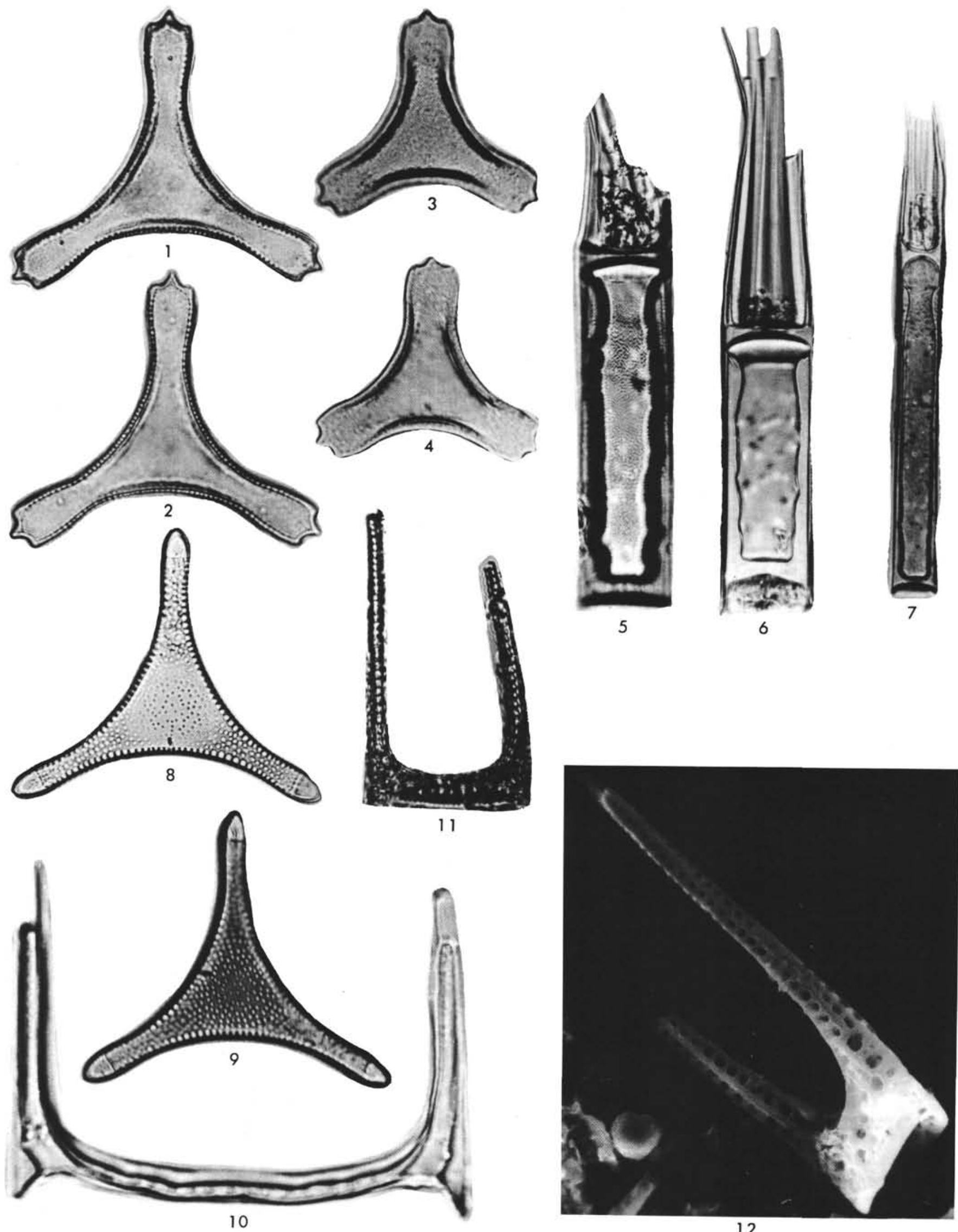

12 
M. HAJÓs

\section{PLATE 16}

Magnifications Figures 1-3, 12-15 ×500; Figures 4-7, 9-11 $\times 1000$

Figures 1-5 Pyrgupyxis gracilis (Temp. et Forti) Hendey var. saratoviana (Pant.) Hendey

Sample 283-4, CC.

Figures 6,7 Pterotheca aculeifera Grun.

Sample 283-5-1, 65-67 cm.

Figure $8 \quad$ Pterotheca aculeifera Grun.

Stereoscan micrograph $\times 2860$. Sample 283-5, CC.

Figures 9-11 Pyrgupyxis johnsoniana (Forti) Hendey.

Sample 283-5, CC.

Figures 12,13 Pterotheca danica Grun.

Sample 283-6, CC.

Figures 14, 15 Pterotheca danica Grun.

Sample 283-6, CC.

Figure 16 Pyrgupyxis johnsoniana (Forti) Hendey.

Stereoscan micrograph $\times 2200$. Sample 283-5, CC. 
PLATE 16

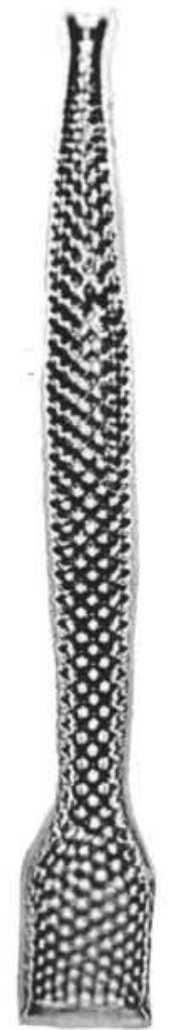

1

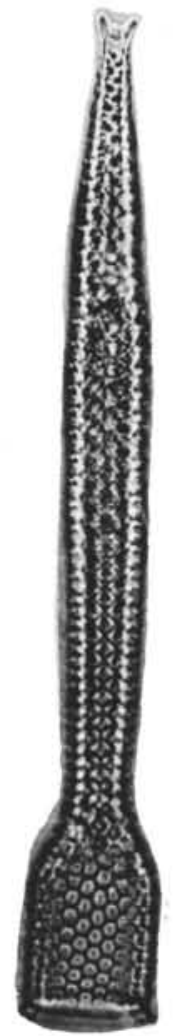

2

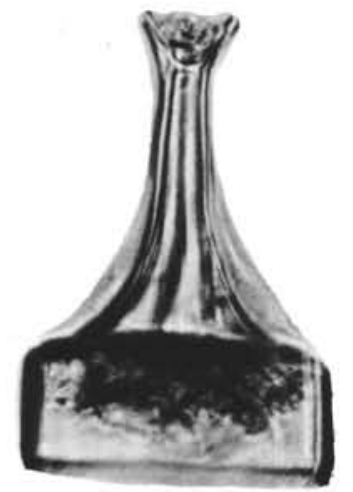

12

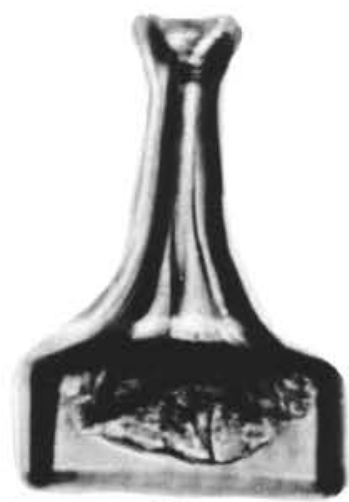

13
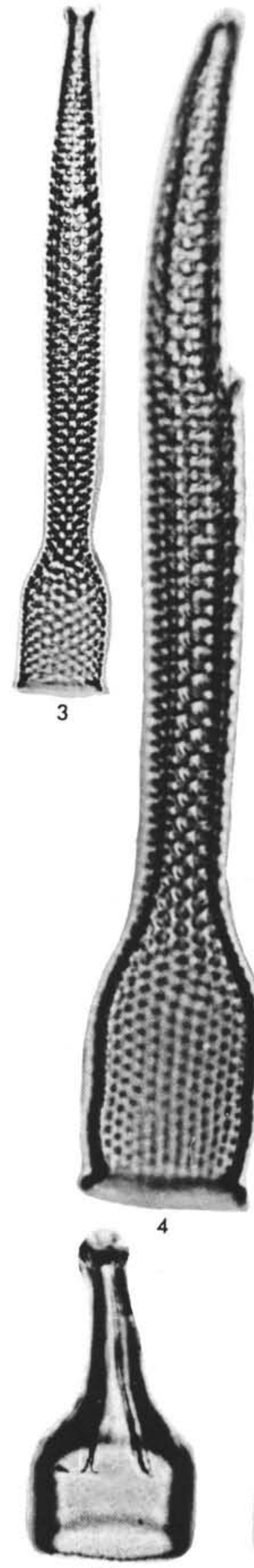

14
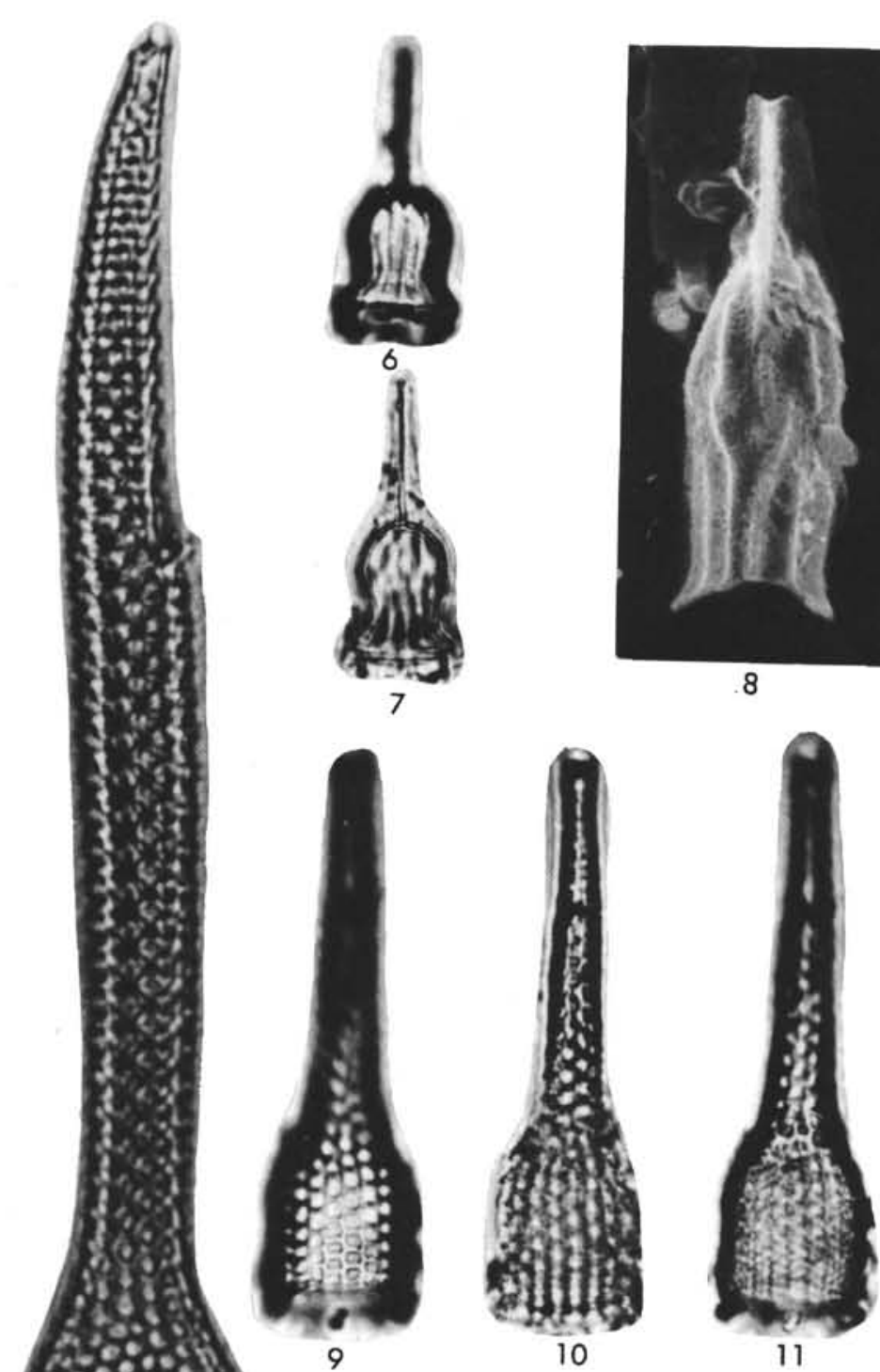

11

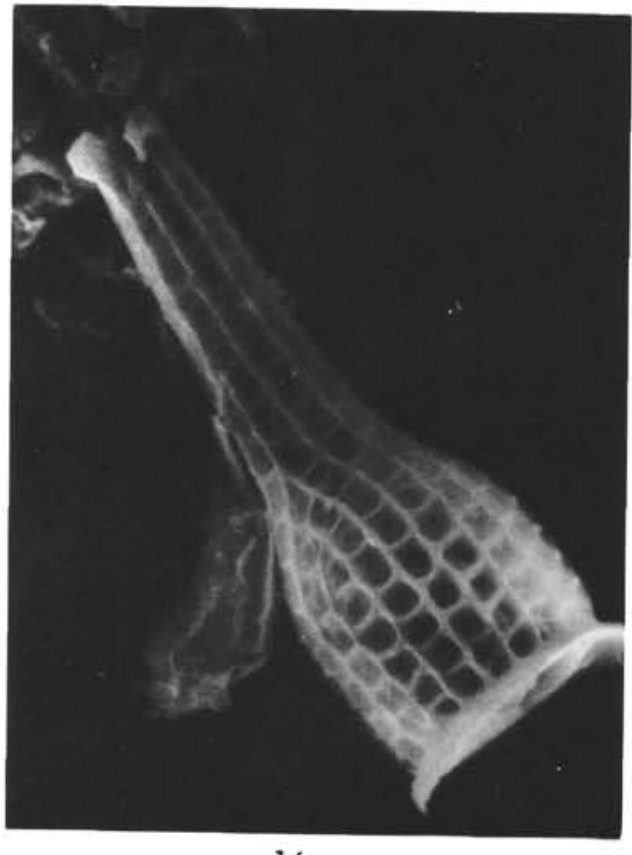

16
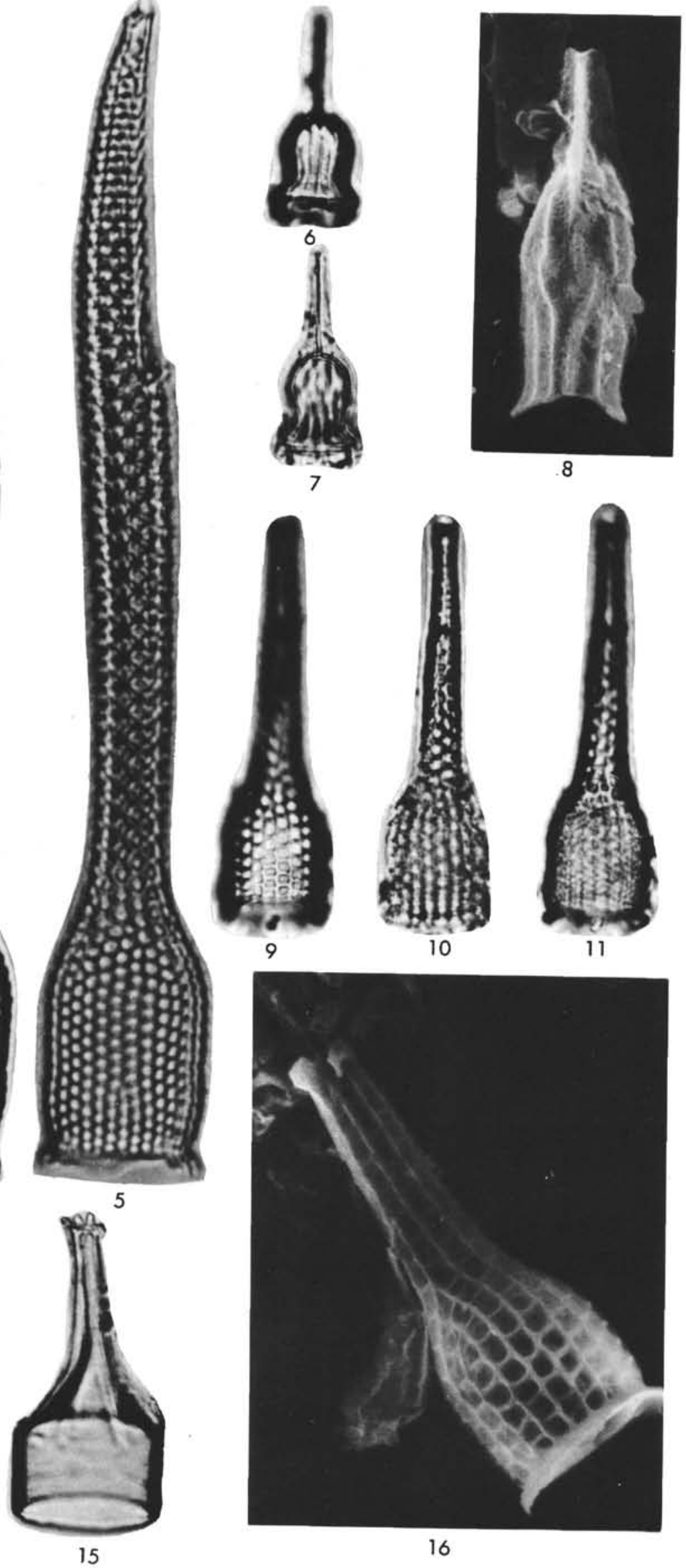


\section{PLATE 17}

Magnifications Figures 1, 2, 4, 7-13 $\times 1000$; Figures 3, 5-6 $\times 500$

Figures 1,2 Liradiscus ovalis Grev. Sample 283-8, CC.

Figure 3 Poretzkia? sp.

Sample 283-3, CC.

Figure $4 \quad$ Xanthiopyxis acrolopha Forti.

Sample 283-4, CC.

Figures 5,6 Acanthodiscus rugosus Pant.

Sample 283-3, CC.

Figures 7,8 Stephanogonia cf. polyacantha Forti.

Sample 283-2, CC.

Figure $9 \quad$ Xanthiopyxis panduraeformis Pant.

Sample 283-8, CC.

Figures 10,12 Xanthiopyxis cf. acrolopha Forti.

Sample 283-5-1, 65-67 cm.

Figure $11 \quad$ Xanthiopyxis oblonga Ehr.

Sample 283-4, CC.

Figure $13 \quad$ Goniothecium odontella Ehr.

Sample 283-4, CC. 
PLATE 17
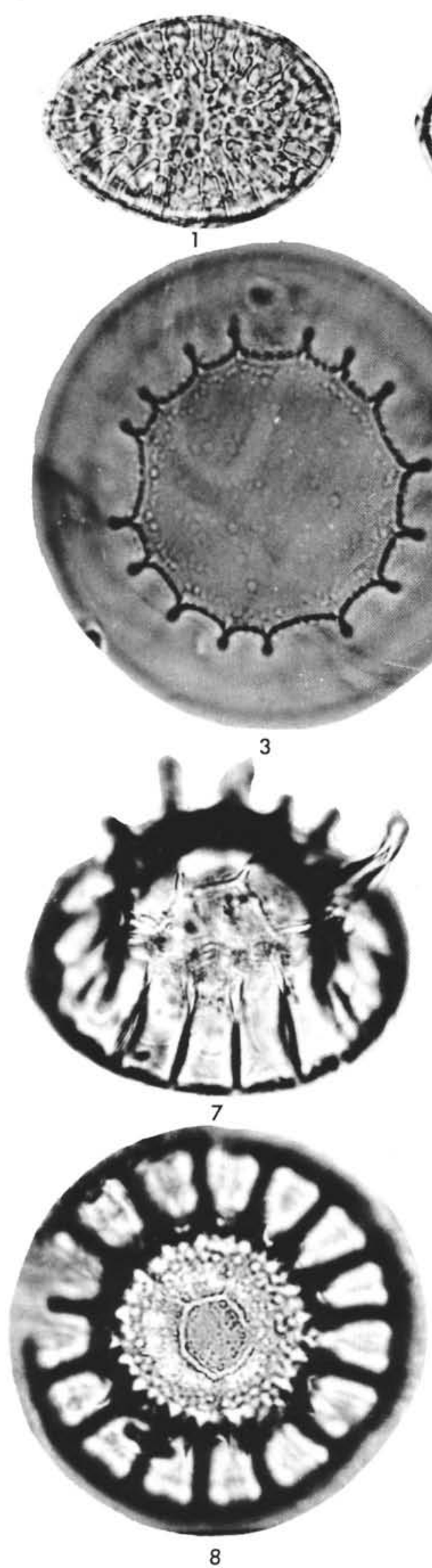

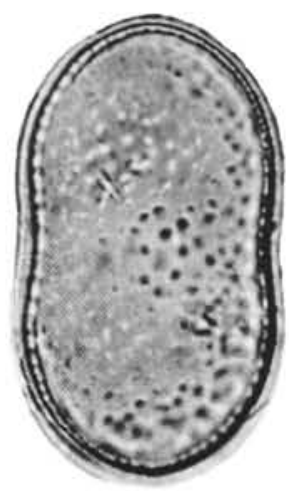

9

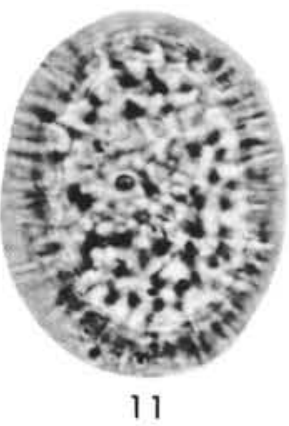

11
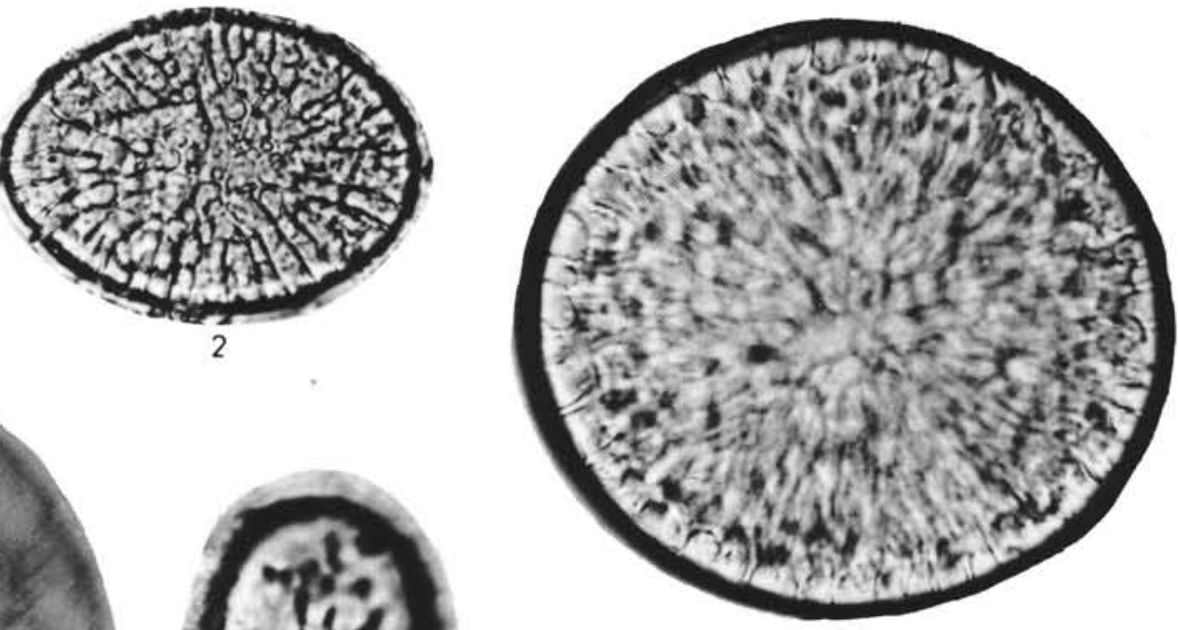
5
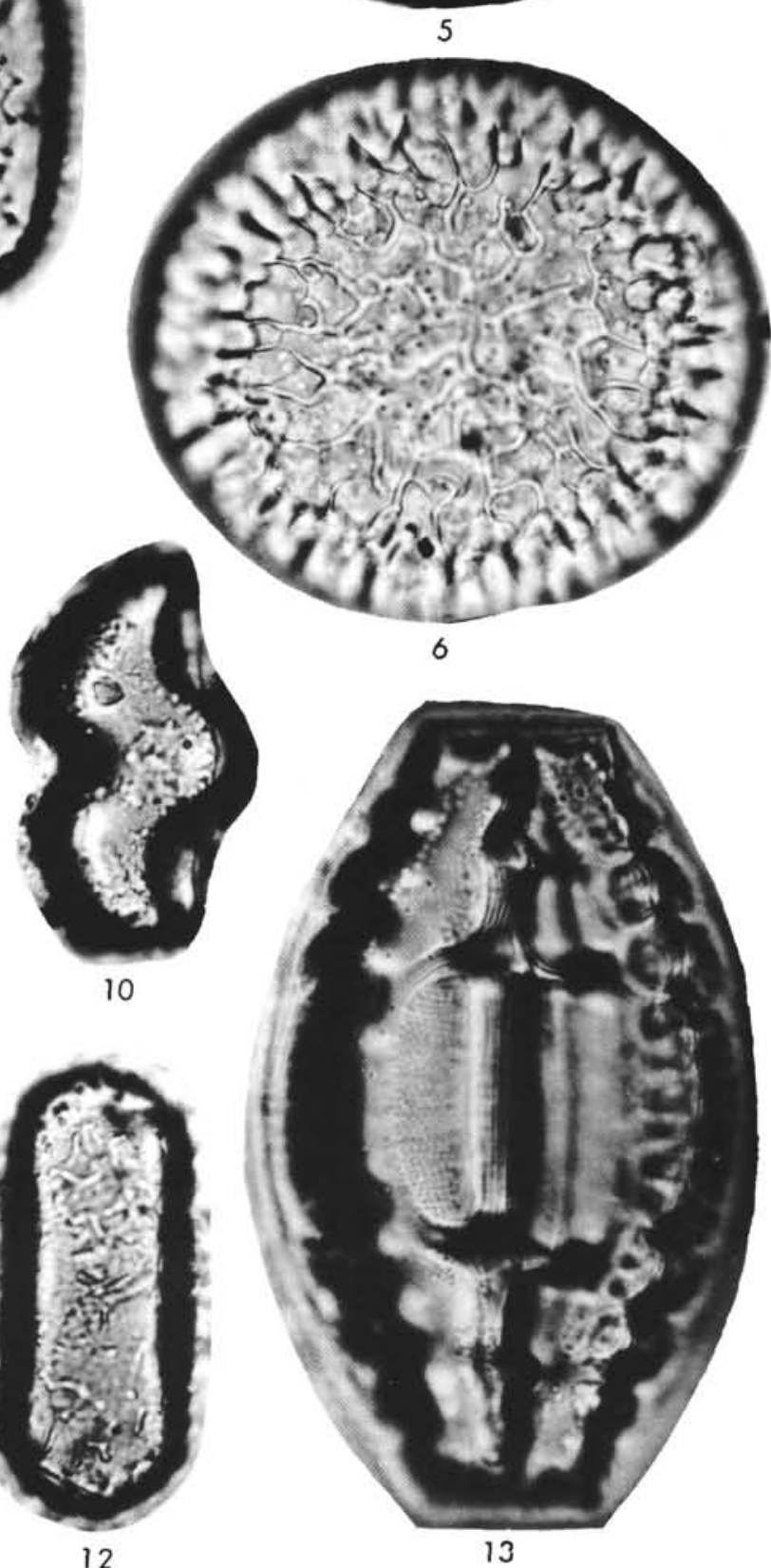


\section{PLATE 18}

Magnifications Figures 1-16, 18, 20-21 ×1000; Figures 17, $19 \times 500$

Figures 1-3 Archaeomonas oamaruensis Defl. Sample 283-6, CC.

Figures 4, 5 Archaeomonas dubia Defl. Sample 283-6, CC.

Figures 6-8 Archaeosphaeridium armatum n. sp. Sample 283-6, CC. 6-7. Holotype

Figures 9, 10 Pararchaeomonas decorata n. sp. Holotype. Sample 283-4, CC.

Figures 11, 12 Pararchaeomonas? rigaudae Rampi. Sample 283-4, CC.

Figures 13,14 Archaeomonas reticulosa Defl. Sample 283-4, CC.

Figure 15 Dictyocha fibula Ehr. Sample 283-2, CC.

Figure 16 Dictyocha fibula Ehr. Sample 283-3, CC.

Figures 17, 19 Porifera spicules Sample 283-6, CC.

Figure 18 Mesocena apiculata (Schulz) Hanna. Sample 283-6, CC.

Figure $20 \quad$ Naviculopsis biapiculata (Lemm.) Freng. Sample 283-2, CC.

Figure $21 \quad$ Naviculopsis biapiculata (Lemm.) Freng. var. constricta (Schulz) Glezer.

Sample 283-4, CC. 
PLATE 18

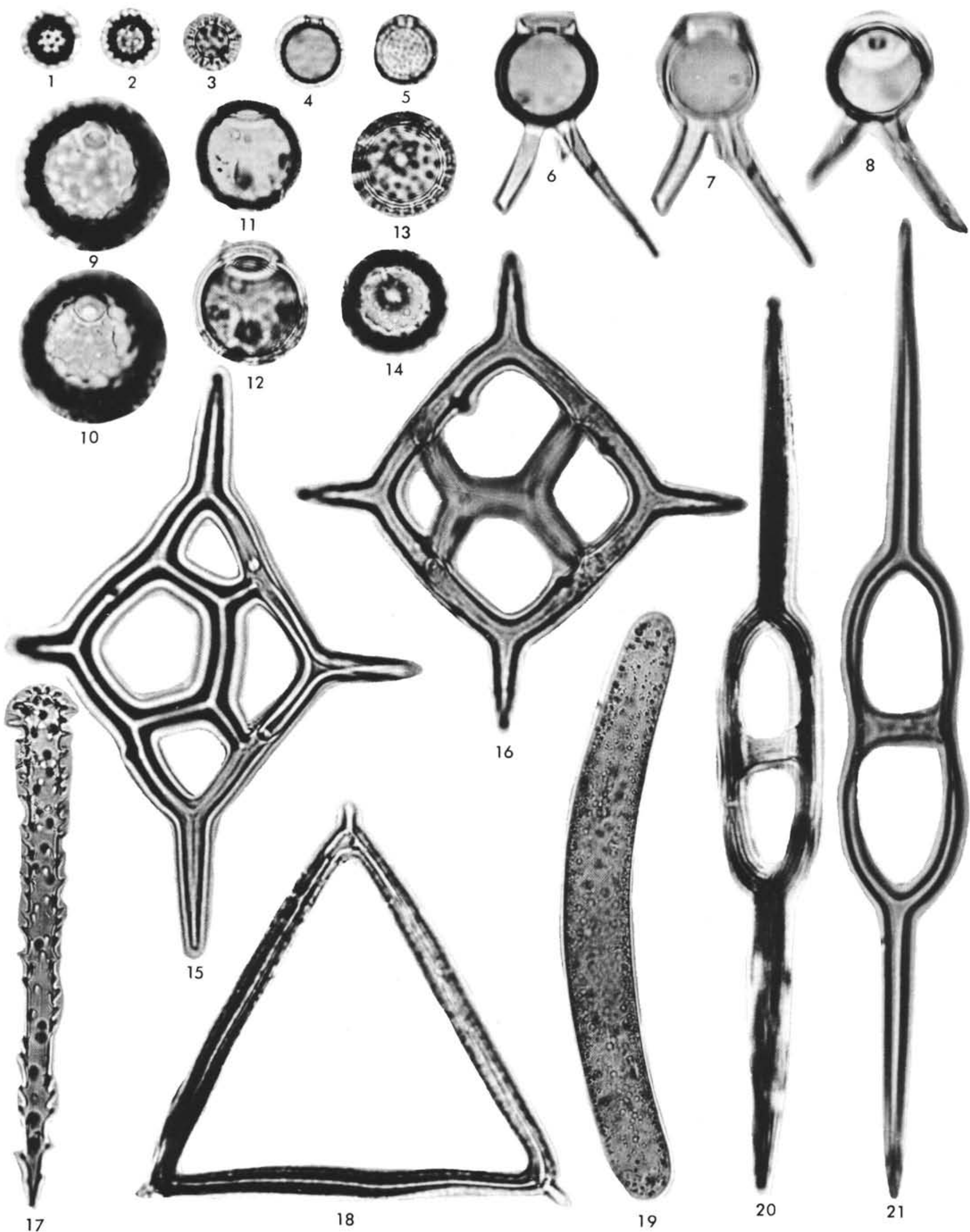


PLATE 19

Magnifications $\times 1000$

Figures 1,2 Endictya robusta (Grev.) Hanna et Grant.

Sample 280A-6-3, 120-122 cm.

Figures 3,4 Stephanopyxis oligocaenica n. sp. Holotype. Sample 280A-7-2, 120-122 cm.

Figures 5,6 Stephanopyxis oamaruensis n. sp. Sample 280A-7-2, 120-122 cm.

Figures 7,8 Stephanopyxis oamaruensis n. sp. Holotype. Sample 280A-3-4, 120-122 cm.

Figures 9, 10 Stephanopyxis sp.

Sample 280A-3-4, 120-122 cm.

Figures 11, 12 Stephanopyxis hyalomarginata n. sp. Holotype. Sample 280A-7-2, 120-122 cm. 
PLATE 19

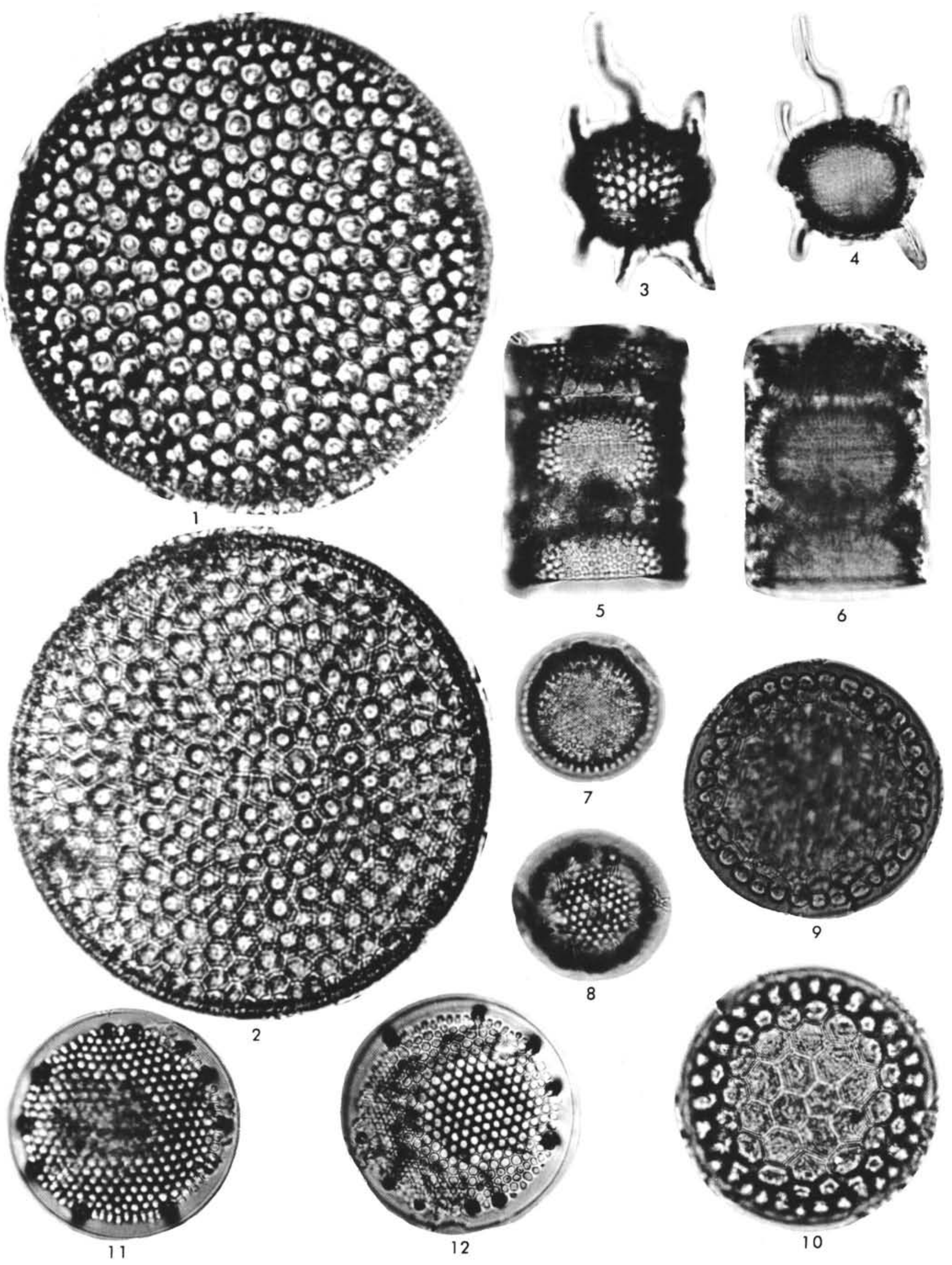




\section{PLATE 20}

Magnifications $\times 1000$

Figures 1-3 Stephanopyxis longispinosa n. sp. Holotype. Sample 280A-3-4, 120-122 cm.

Figures 4, 5 Stephanopyxis inordinata n. sp. Holotype. Sample 280A-3-4, 120-122 cm.

Figures 6-8 Coscinodiscus tuberculatus Grev. Sample 280A-6-3, 120-122 cm.

Figures 9, 10 Coscinodiscus marginatus Ehr. Sample 280A-6-3, 120-122 cm.

Figures 11, 12 Coscinodiscus symbolophorus Grun. Sample 280A-8-1, 120-122 cm.

Figures 13,14 Coscinodiscus cf. moelleri A. Schm. var. macroporus Grun.

Sample 280A-3-4, 120-122 cm.

Figure 15 Coscinodiscus symbolophorus Grun. var. oamaruensis A. Schm.

Sample 280A-6-3, 120-122 cm. 
PLATE 20
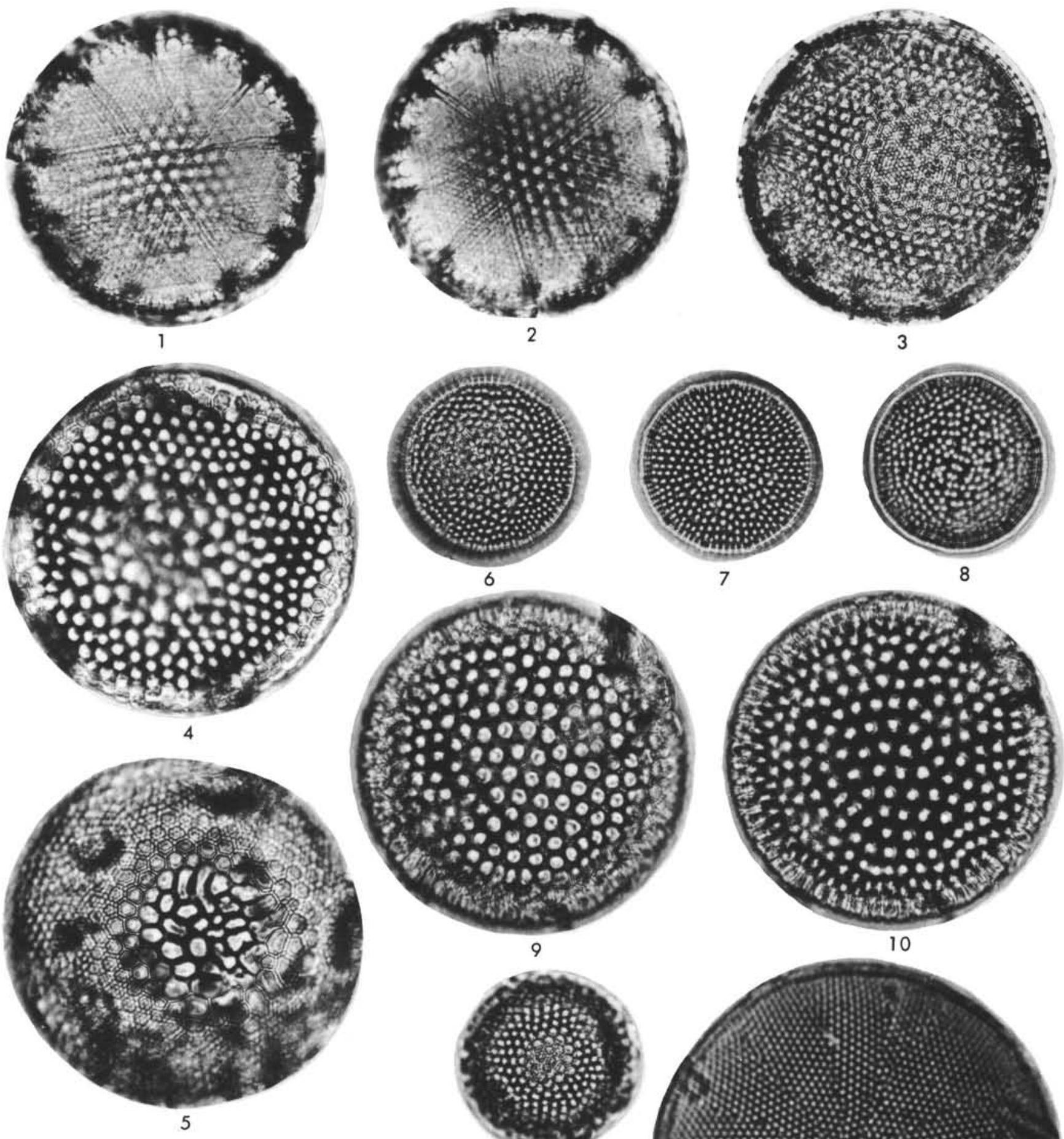

9

10

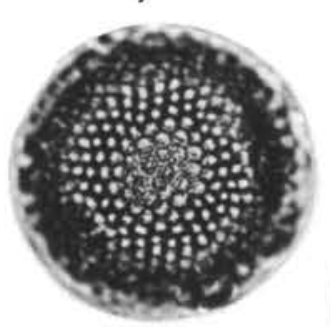

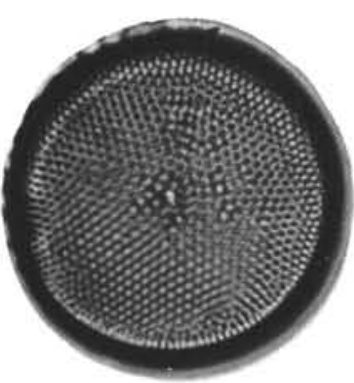

11

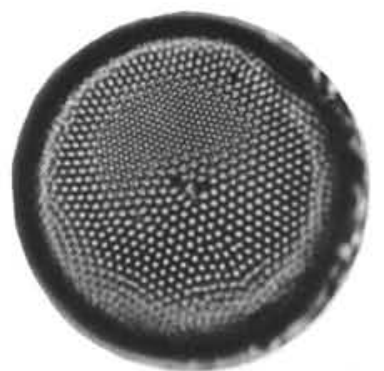

12

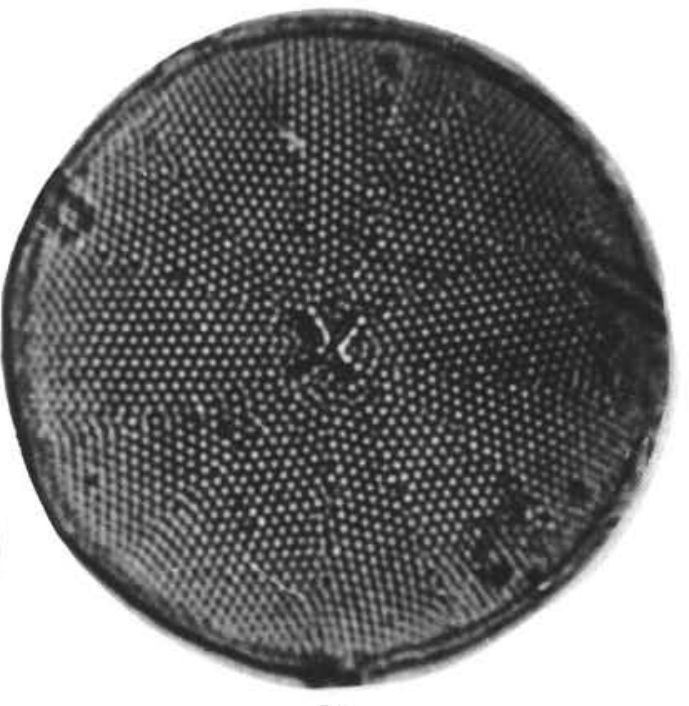

15 
M. HAJÓS

\section{PLATE 21}

Magnifications $\times 1000$

Figures 1,2 Stictodiscus nitidus Gr. et St.

Sample 280A-3-4, 120-122 cm.

Figures 3, $4 \quad$ Liradiscus sp.

Sample 280A-3-4, 120-122 cm.

Figure $5 \quad$ Xanthiopyxis cf. acrolopha Forti. Sample 280A-6-3, 120-122 cm.

Figure 6 Asterolampra schmidti n. sp. Holotype. Sample 280A-6-3, 120-122 cm.

Figure $7 \quad$ Triceratium arcticum Brightw. Sample 280A-2-3, 20-22 cm.

Figure $8 \quad$ Rhizosolenia interposita n. sp. Holotype. Sample 280A-6-3, 120-122 cm.

Figures 9, 10 Triceratium chenevieri Meist. Sample 280A-6-3, 120-122 cm.

Figures 11, 12 Triceratium pulvinar A. Schm. Sample 280A-6-3, 120-122 cm. 
PLATE 21
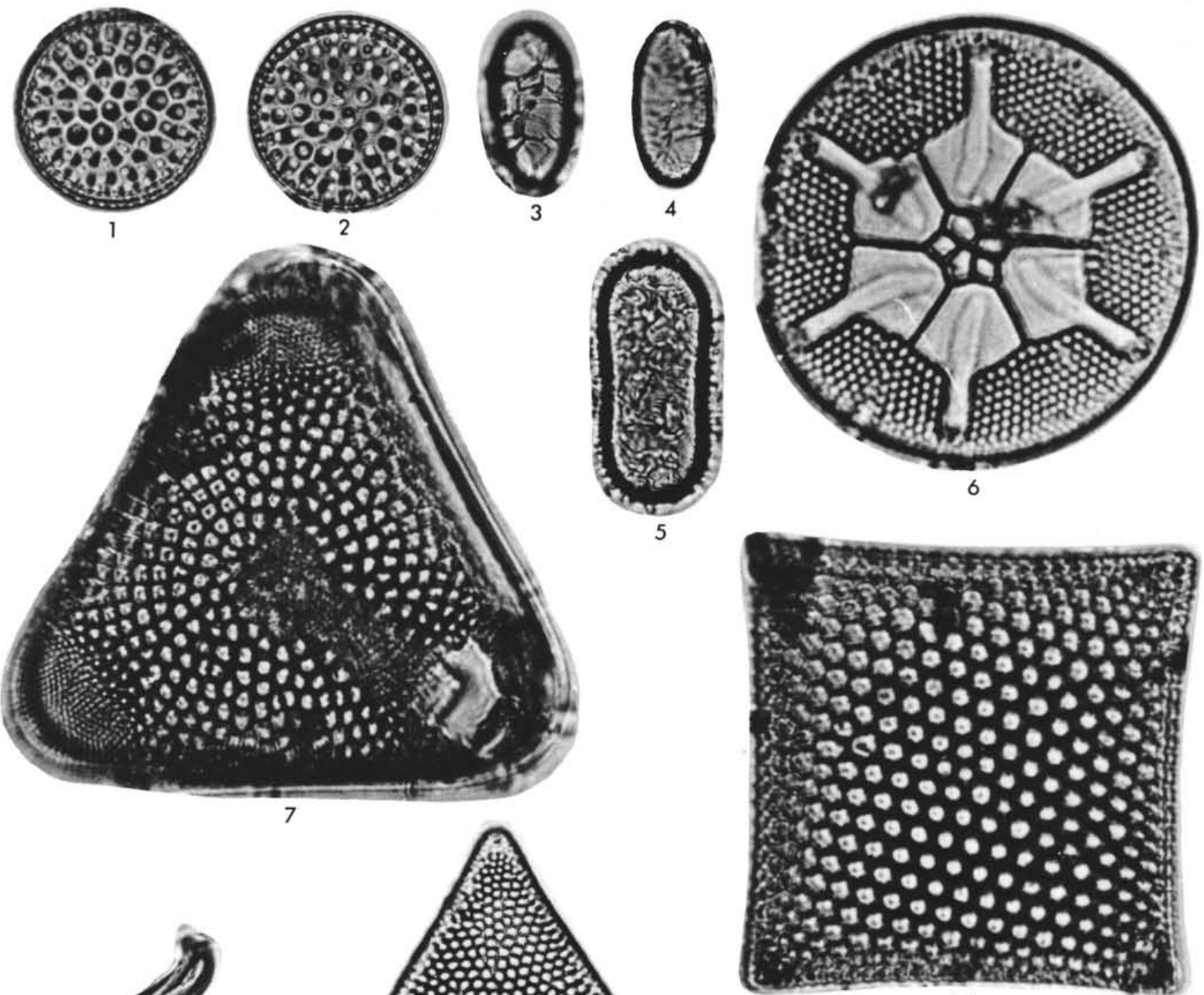

11

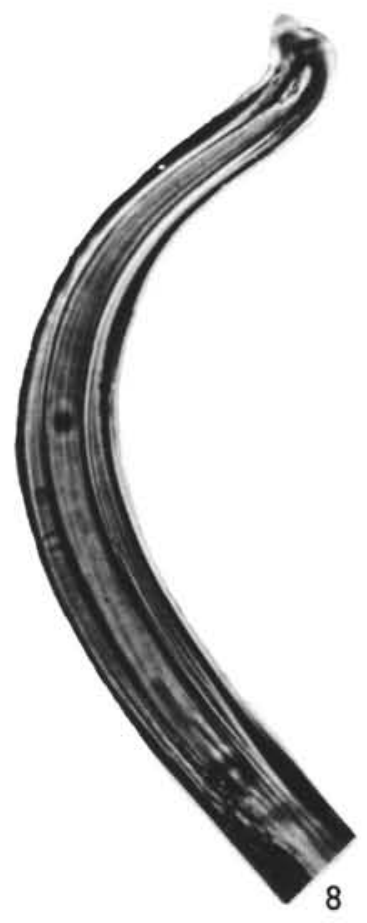

7
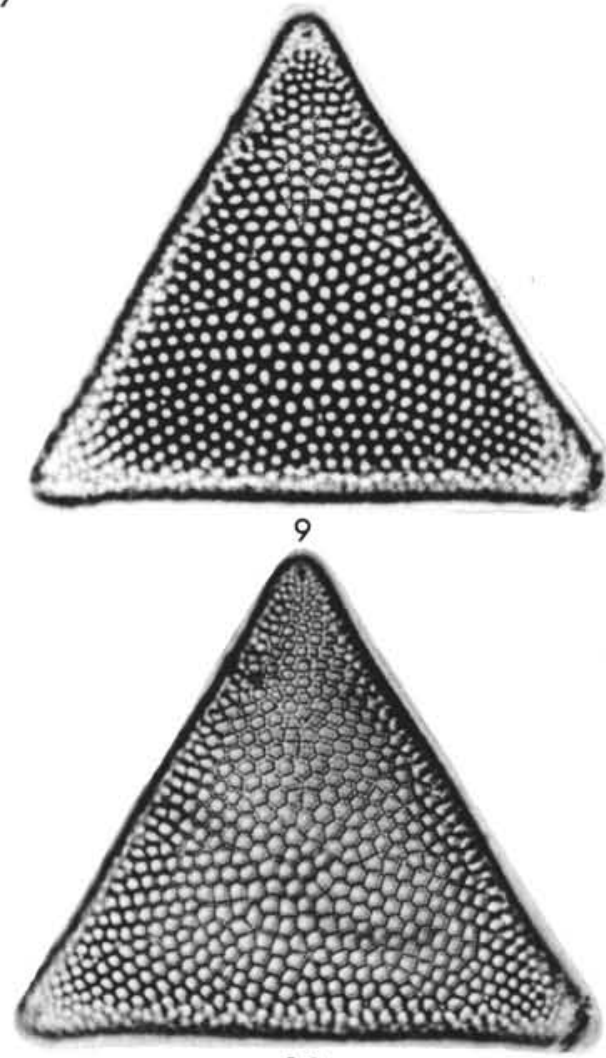

10

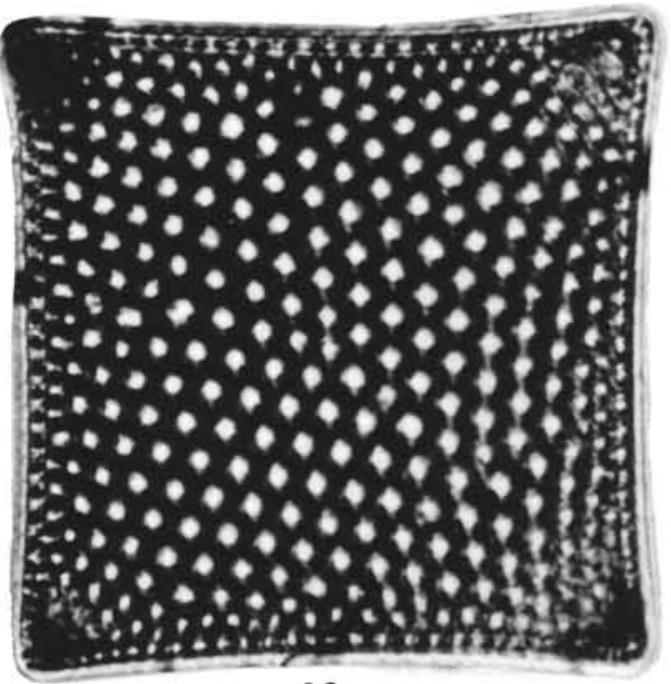

12 
PLATE 22

Magnifications $\times 1000$

Figures 1, 2 Cerataulus pacificus n. sp. Holotype. Sample 280A-1-2, 9-11 cm.

Figures 3,4 Cerataulus pacificus n. sp.

Sample 280A-6-3, 120-122 cm.

Figure $5 \quad$ Cerataulus pacificus n. sp.

Sample 280A-2-2, 20-22 cm.

Figure $6 \quad$ Cerataulus pacificus n. sp. Sample 280A-1-2, 9-11 cm.

Figure $7 \quad$ Biddulphia fimbriata Grev. Sample 280A-6-3, 120-122 cm.

Figure $8 \quad$ Biddulphia fimbriata Grev. Sample 280A-7-2, 120-122 cm. 


\section{PLATE 22}

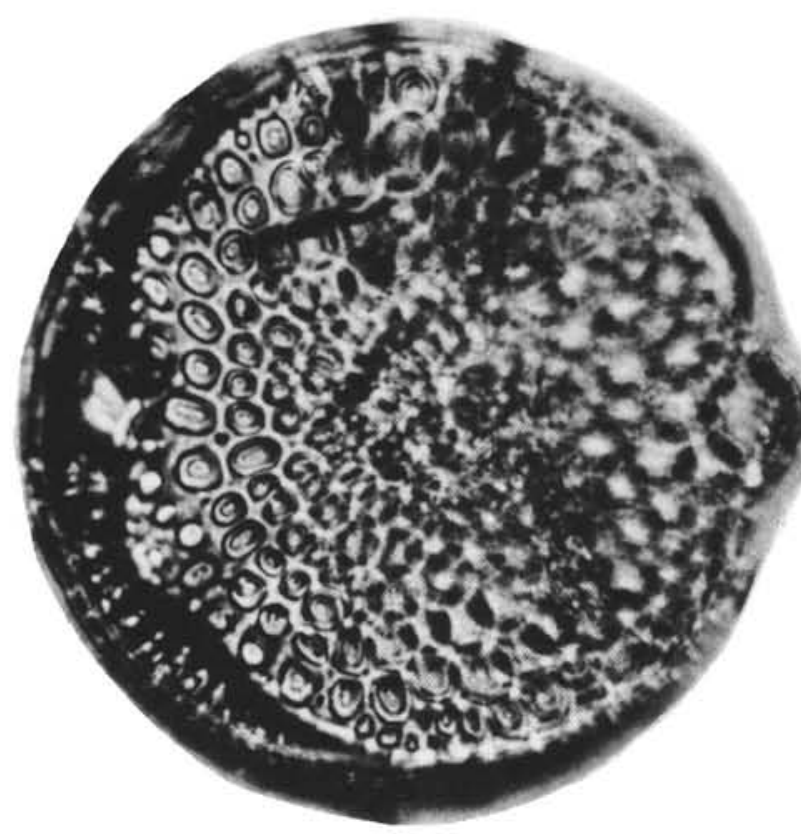

1

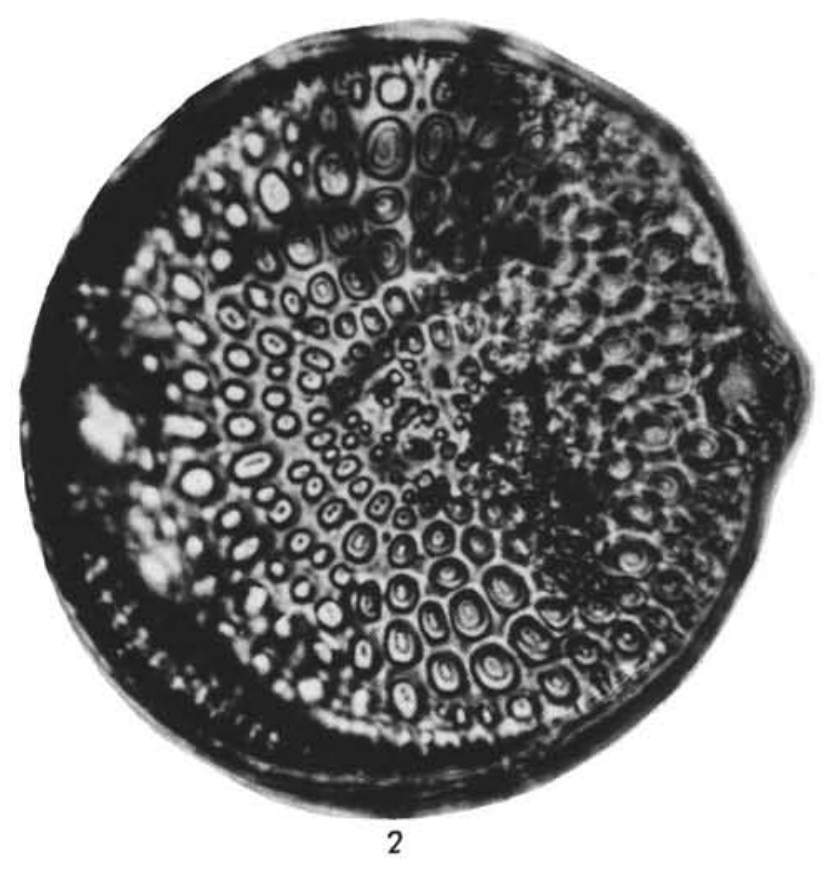

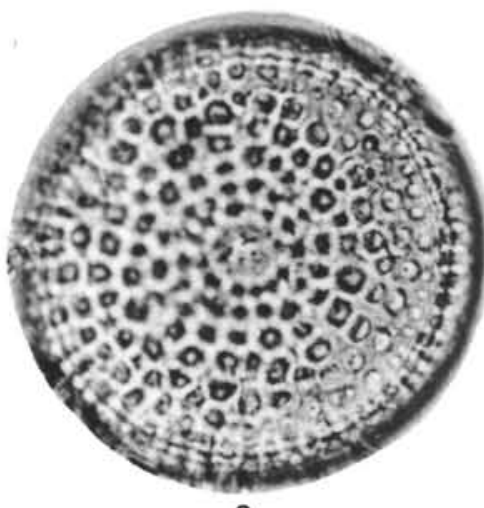

3
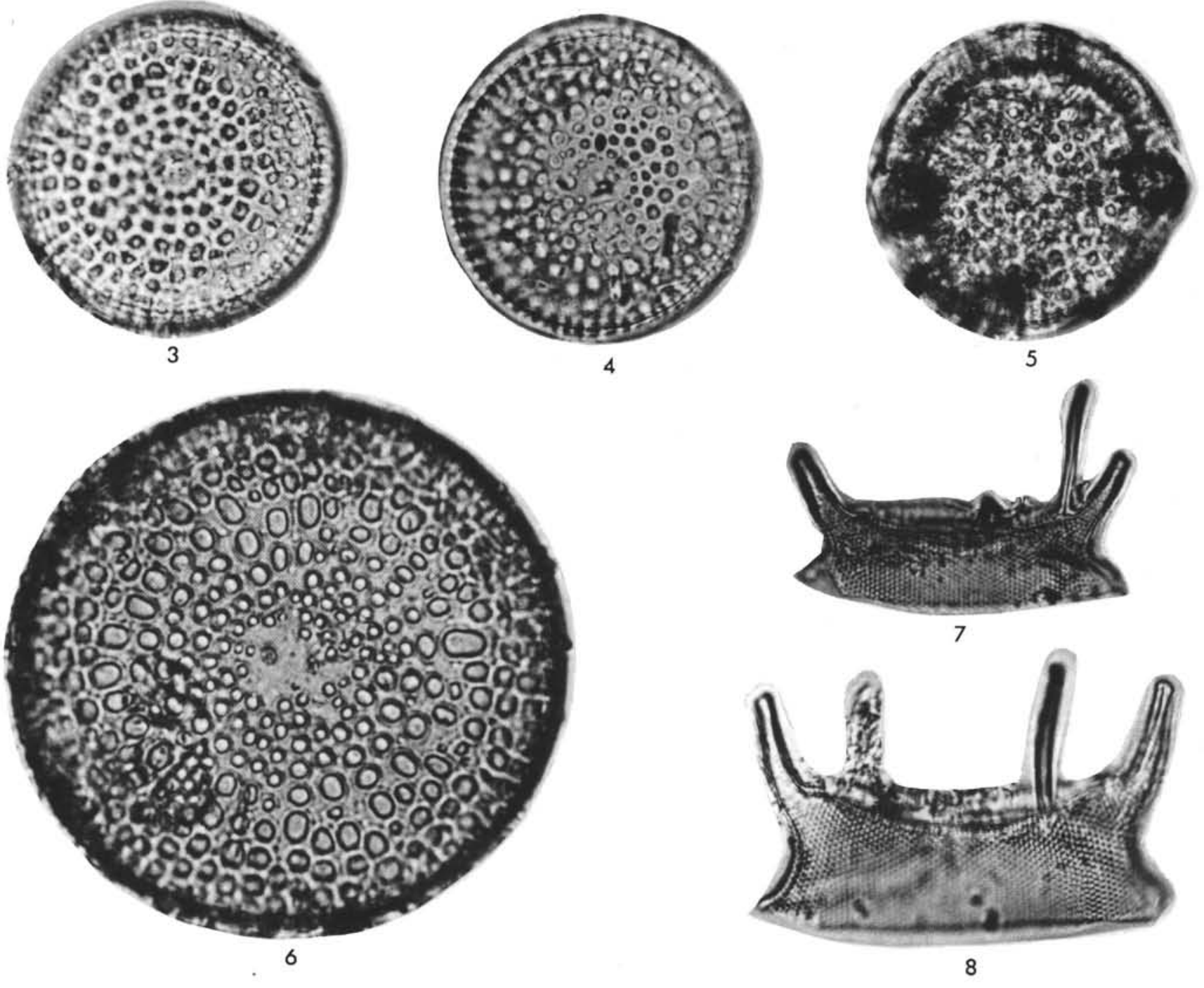
PLATE 23

Magnifications $\times 1000$

Figure 1 Trinacria excavata Heib.

Sample 280A-6-3, 120-122 cm.

Figures 2, 3 Hemiaulus polymorphus Grun.

Sample 280A-6-3, 120-122 cm.

Figures 4, $5 \quad$ Hemiaulus incisus $\mathrm{n}$. sp.

Sample 280A-6-3, 120-122 cm.

Figures 6,7 Hemiaulus incisus $\mathrm{n}$. sp. Holotype.

Sample 280A-6-3, 120-122 cm.

Figure 8 Hemiaulus incisus n. sp.

Stereoscan micrograph $\times 1600$.

Sample 280A-5-1, 110-112 cm.

Figure 9 Hemiaulus incisus $\mathrm{n}$. sp.

Stereoscan micrograph $\times 8000$.

Detail of the structure of the valve mantle. Sample 280A-5-1, 110-112 cm. 
PLATE 23

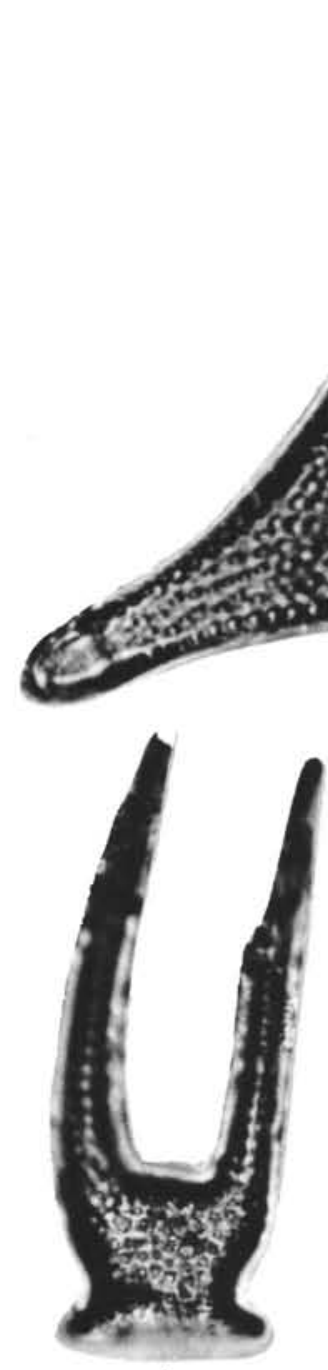

4
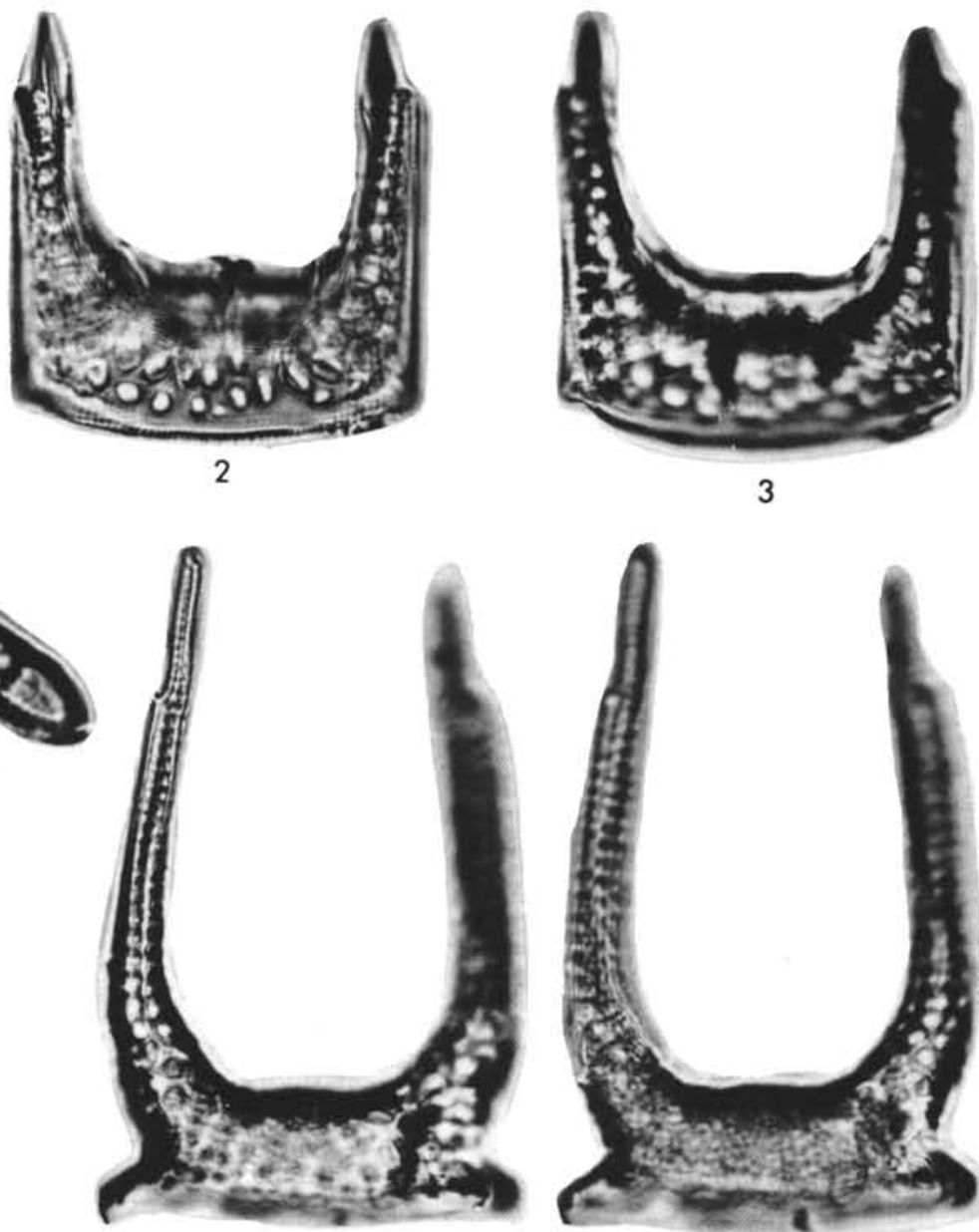

6
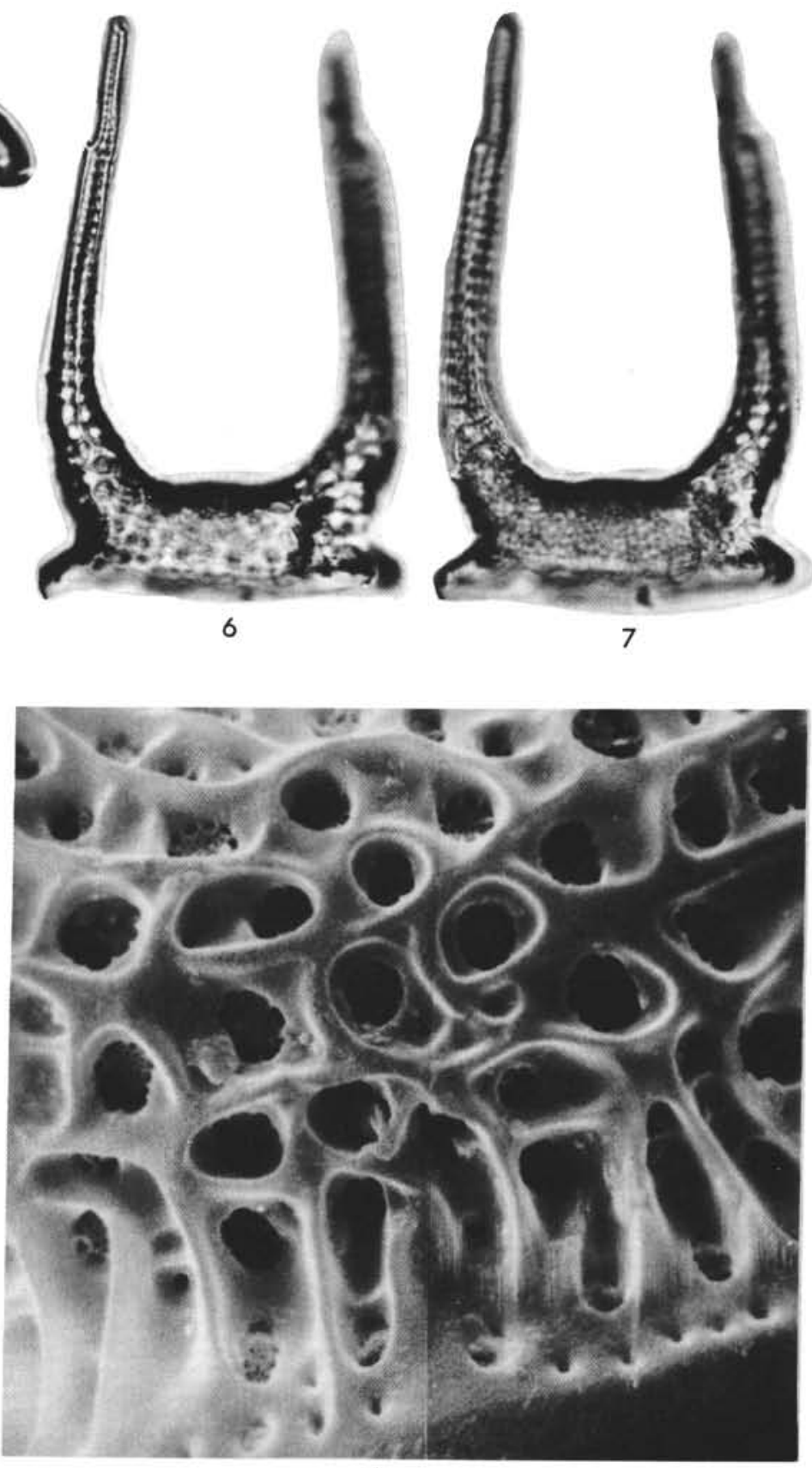

9 
M. HAJÓS

\section{PLATE 24}

Magnifications $\times 1000$

Figures 1, 2 Pyrgupyxis johnsoniana (Forti) Hendey var. intermedia (Temp. et Forti) Hendey. Sample 280A-6-3, $120-122 \mathrm{~cm}$.

Figures 3-5 Pyrgupyxis eocena Hendey. Sample 280A-6-3, 120-122 cm.

Figures 6,7 Pyrgupyxis johnsoniana (Forti) Hendey. Sample 280A-6-3, 120-122 cm.

Figures 8, 9 Pyrgupyxis eocena Hendey. Sample 280A-6-3, 120-122 cm.

Figures 10,11 Pyrgupyxis johnsoniana (Forti) Hendey. Sample 280A-6-3, 120-122 cm.

Figure 12 Pyrgupyxis johnsoniana (Forti) Hendey. Stereoscan micrograph $\times 1600$. Sample 280A-5-1, 110-112 cm. 
PLATE 24

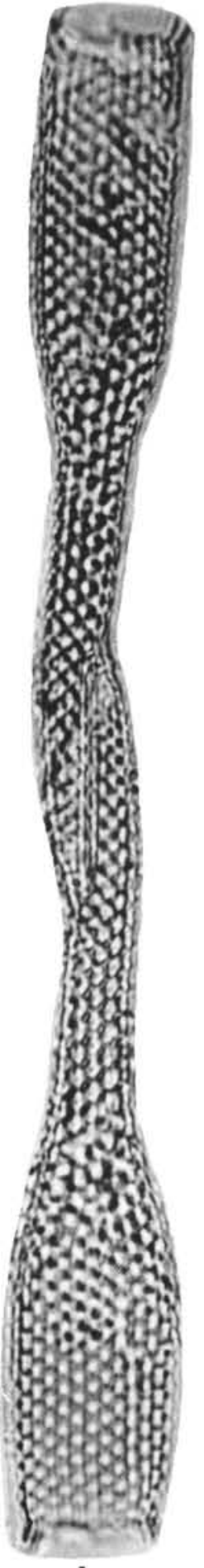

1
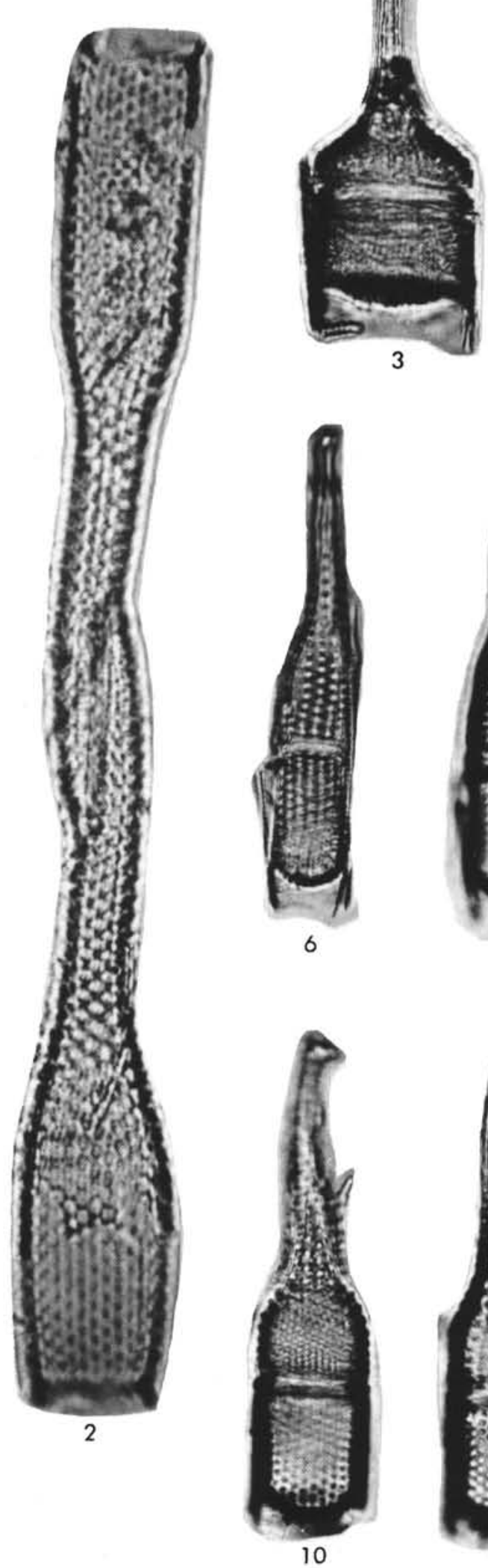
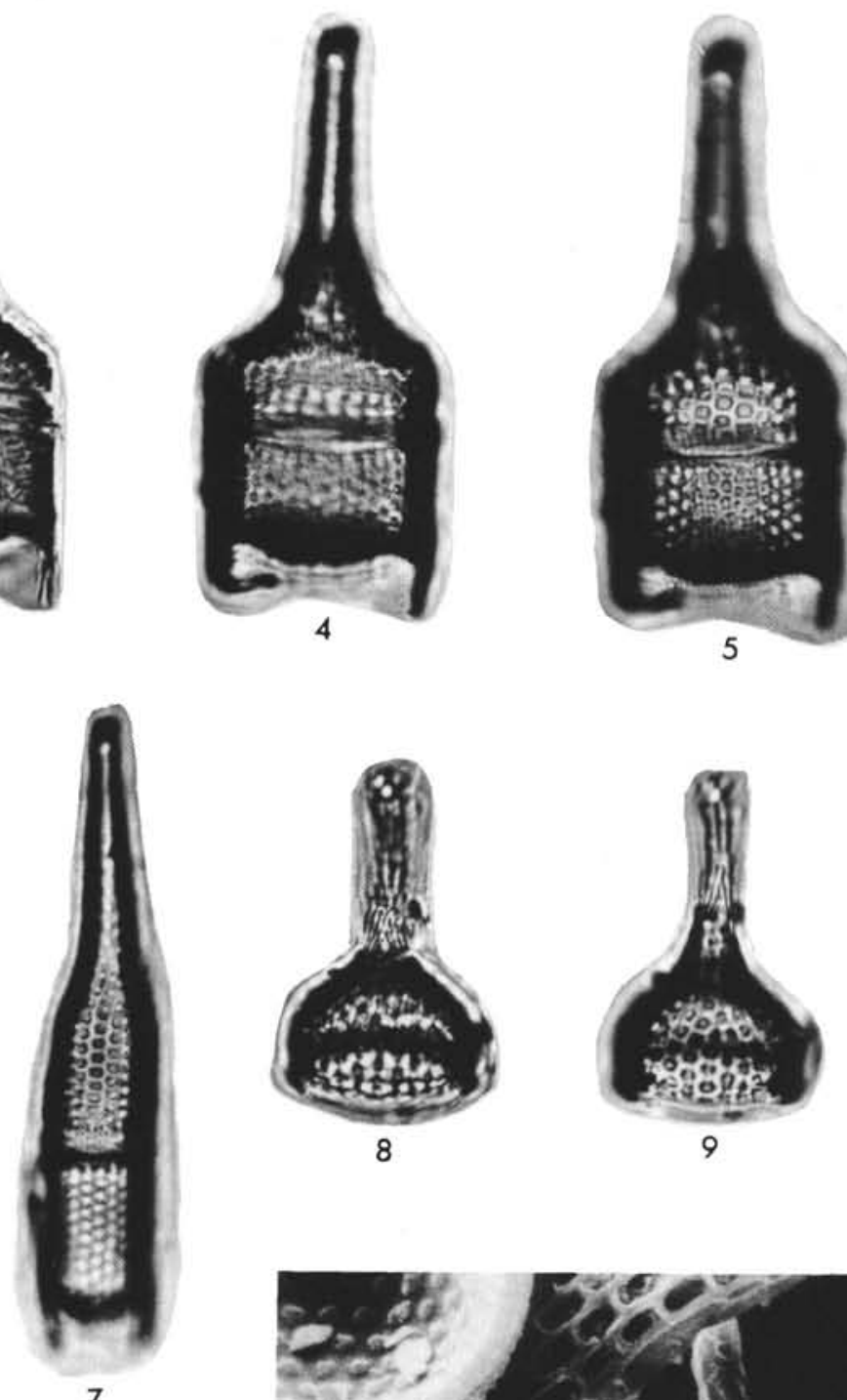
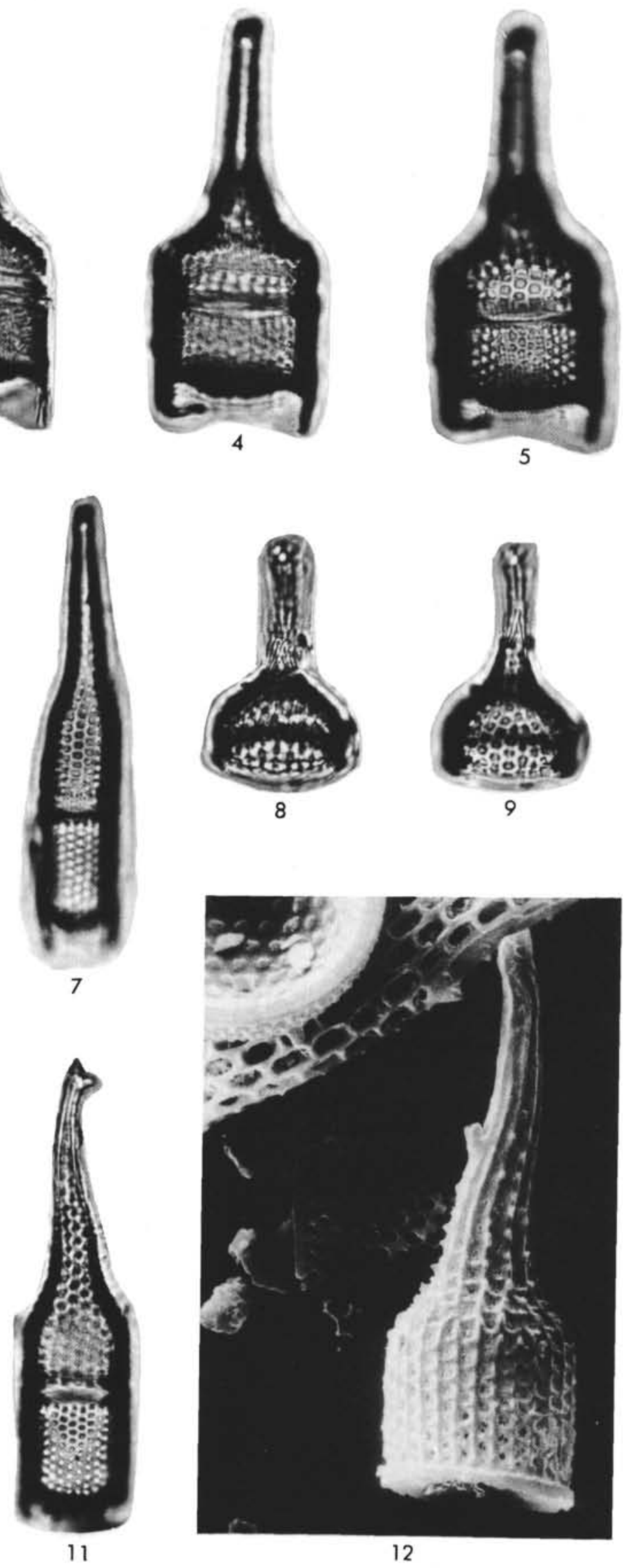
PLATE 25

Magnifications $\times 1000$

Figures 1,2 Goniothecium odontella Ehr.

Sample 280A-3-4, 120-122 cm.

Figures 3, 4 ?Hercotheca inermis Mann.

Sample 280A-2-2, 15-17 cm.

Figures 5,6 Kisseleviella carina Shesh.

Sample 280A-2-3, 20-22 cm.

Figures 7-9 Kisseleviella carina Shesh.

Sample 280A-7-2, 120-122 cm.

Figures 10,11 Rouxia rouxioides (Schrader) n. comb.

Sample 280A-6-3, 120-122 cm.

Figures 12, 13 Rouxia rouxioides (Schrader) n. comb.

Sample 280A-6-3, 120-122 cm.

Figure $14 \quad$ Kisseleviella carina Shesh.

Stereoscan micrograph $\times 3200$. Sample 280A-5-1, $110-112 \mathrm{~cm}$.

Figures 15, 16 Archaeomonas ovalis Defl.

Sample 280A-6-3, 120-122 cm.

Figure 17 Mesocena apiculata (Schulz) Hanna.

Sample 280A-1-2, 9-11 cm.

Figure 18 Dictyocha deflandrei Freng.

Sample 280A-3-4, 120-122 cm.

Figure 19 Naviculopsis trispinosa (Schulz) Gleser.

Sample 280A-3-4, 120-122 cm. 
DIATOMACEAE, ARCHAEOMONADACEAE, AND SILICOFLAGELLATAE

PLATE 25
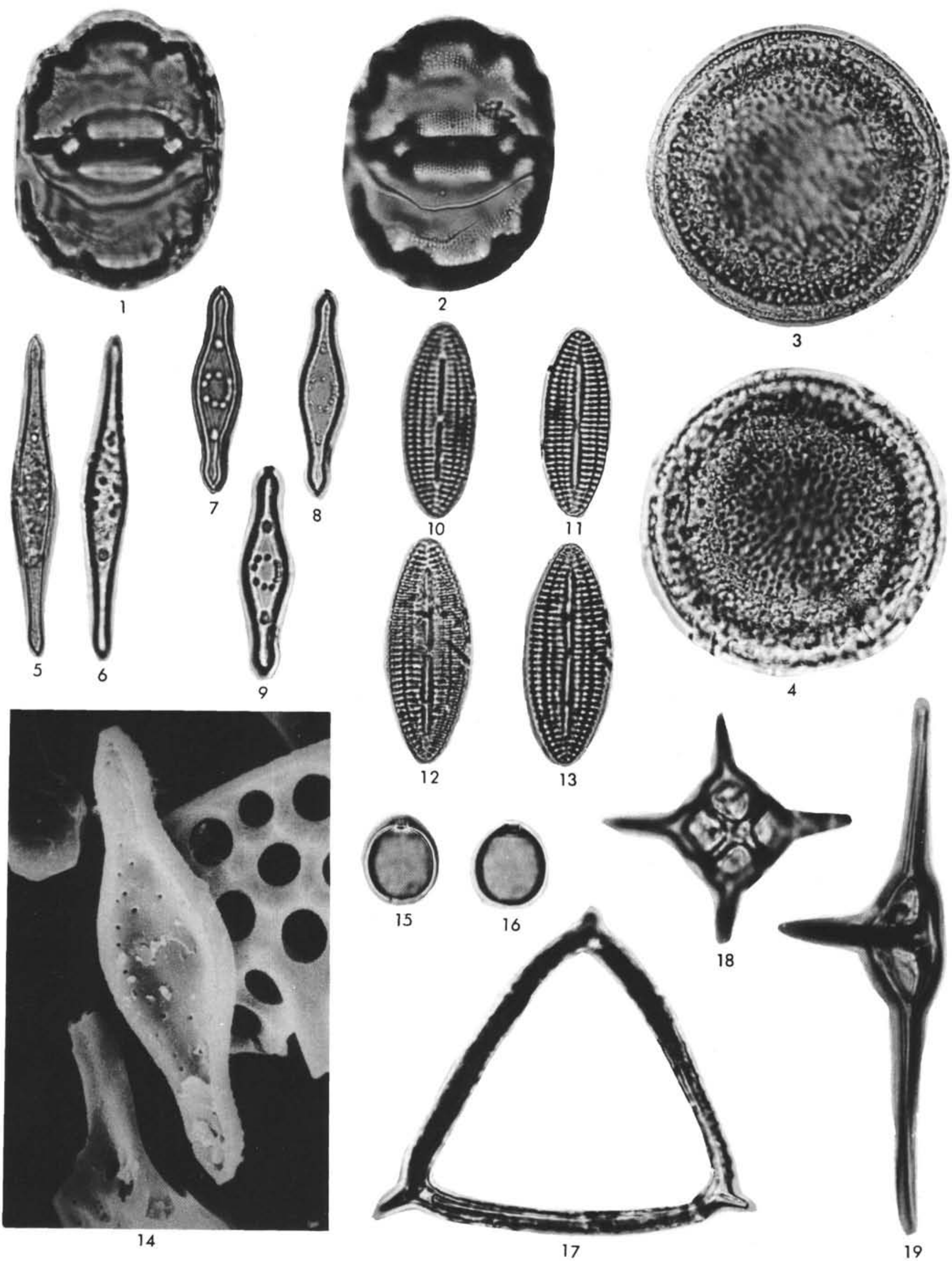